\title{
ALTERNATIVE ANALYTICAL DIGESTION SCHEME FOR THE DEFENSE WASTE PROCESSING FACILITY (DWPF) SLURRY RECEIPT AND ADJUSTMENT TANK (SRAT) ANALYSES
}

D. R. Click

C. J. Coleman

K. E. Zeigler

T. B. Edwards

F. M. Pennebaker

September 17, 2007 
WSRC-STI-2007-00515

Revision 0

This page intentionally left blank 


\section{DISCLAIMER}

This report was prepared by Washington Savannah River Company (WSRC) for the United States Department of Energy under Contract No. DE-AC09-96SR18500 and is an account of work performed under that contract. Neither the United States Department of Energy, nor WSRC, nor any of their employees makes any warranty, expressed or implied, or assumes any legal liability or responsibility for the accuracy, completeness, or usefulness, of any information, apparatus, or product or process disclosed herein or represents that its use will not infringe privately owned rights. Reference herein to any specific commercial product, process, or service by trademark, name, manufacturer or otherwise does not necessarily constitute or imply endorsement, recommendation, or favoring of same by WSRC or by the United States Government or any agency thereof. The views and opinions of the authors expressed herein do not necessarily state or reflect those of the United States Government or any agency thereof.

\section{Printed in the United States of America \\ Prepared For U.S. Department of Energy}


WSRC-STI-2007-00515

Revision 0

This page intentionally left blank 
WSRC-STI-2007-00515

Revision 0

Key Words: method development, Simulant development, process verification

Retention: Permanent

\section{ALTERNATIVE ANALYTICAL DIGESTION SCHEME FOR THE DEFENSE WASTE PROCESSING FACILITY (DWPF) SLURRY RECEIPT AND ADJUSTMENT TANK (SRAT) ANALYSES}

D. R. Click

C. J. Coleman

K. E. Zeigler

T. B. Edwards

F. M. Pennebaker

September 17, 2007 
WSRC-STI-2007-00515

Revision 0

\section{REVIEWS AND APPROVALS}

D.R. Click, Co-Author, Analytical development, SRNL

Date

K.E. Zeigler, Co-Author, Analytical Development, SRNL

Date

C.J. Coleman, Co-Author, Analytical Development, SRNL

Date

T.B. Edwards, Co-Author, Statistical Consulting, SRNL

Date

R. A. Pierce, Technical Reviewer, Actinide Technology Section, SRNL

Date

C.C. Herman, Manager, Process Science Engineering Technology, SRNL

Date

F.M. Pennebaker, Manager, Materials Characterization and Nuclear Measurements, SRNL Date 
WSRC-STI-2007-00515

Revision 0

This page intentionally left blank 


\section{EXECUTIVE SUMMARY}

As part of the radioactive sludge batch qualification, Savannah River National Laboratory (SRNL) performs a verification of the digestion methods to be used by the Defense Waste Processing Facility (DWPF) Lab for elemental analysis of Sludge Receipt and Adjustment Tank (SRAT) receipt process control samples and SRAT product process control samples. ${ }^{1}$ Verification of these methods on Sludge Batch 4 (SB4) radioactive sludge slurry indicated SB4 contains a higher concentration of aluminum (Al) than previous sludge batches. ${ }^{2}$ Aluminum plays a direct role in vitrification chemistry. At moderate levels, $\mathrm{Al}$ assists in glass forming, but at elevated levels $\mathrm{Al}$ can increase the viscosity of the molten glass which can adversely impact glass production rate and the volume of glass produced via limiting waste loading. ${ }^{3}$ Most of the $\mathrm{Al}$ present in SB4 is in the form of $\mathrm{Al}$ hydroxide as a mixture of gibbsite $\left[\alpha\right.$-aluminum trihydroxide, $\left.\alpha-\mathrm{Al}(\mathrm{OH})_{3}\right]$ and boehmite ( $\alpha$-aluminum oxyhydroxide, $\alpha$ $\mathrm{AlOOH}$ ) in an unknown ratio. Testing done at SRNL indicates Gibbsite is soluble at low pH but boehmite has limited solubility in the acid mixture (DWPF Cold Chem Method (CC), $25 \mathrm{~mL}$ nitric acid $\left(\mathrm{HNO}_{3}\right)$ and $25 \mathrm{~mL}$ hydrofluoric acid (HF)) used by DWPF to digest process control samples. ${ }^{2}$ Because Al plays such an important part in vitrification chemistry, it is necessary to have a robust digestion method that will dissolve all forms of $\mathrm{Al}$ present in the radioactive sludge while not increasing the analytical lab turnaround time.

SRNL initially suggested that the DWPF lab use the sodium peroxide/hydroxide fusion (PF) digestion method $^{4}$ to digest SRAT receipt and SRAT product radioactive sludge as an alternative to the acid digestion method to ensure complete digestion based on results obtained from digesting a SB4 radioactive sample. ${ }^{2}$ However, this change may have a significant impact on the DWPF lab analytical turnaround time due to the inefficiency in drying the radioactive sludge contained in a peanut-vial ( 12-16 hrs) prior to performing the PF. Therefore, a modified digestion scheme was tested using simulant sludge that takes advantage of both digestion methods (CC and PF). The experimental work involved 1) performing the CC method on simulant sludge containing both boehmite and gibbsite, 2) filtering the digestate to collect undissolved solids, 3 ) drying the filter and the solids collected ( $2 \mathrm{hr}$ step versus $\sim 12-16 \mathrm{hr}$ step for drying peanut vial full of sludge), 4) heating the solids and filter to 675 ${ }^{\circ} \mathrm{C}$ (causing complete oxidation of the filter), and 5) performing a PF digestion of the solids. The solutions from each type of digestion were analyzed by Inductively Coupled Plasma Emission Spectroscopy (ICP-ES) and the results were combined. The measured Al concentration from the PF digestion on a dried solids basis was $10.7 \%$ with a relative standard deviation of $0.92 \%$ and $10.1 \%$ with a relative standard deviation of $0.43 \%$ from the $\mathrm{CC}+\mathrm{PF}$ digestion. The Al concentration measured in the digestion solutions from the CC method before performing the PF was $\sim 8.8 \mathrm{wt} \%$ of the solubilized solids on a total dried solids basis. The Al hydroxide dissolution results are discussed in this report. Also discussed are the experimental results obtained for all elements DWPF measures and a statistical comparison of that data.

The following conclusions and recommendations are based upon spectroscopic and statistical analysis of results from experimental digestion tests conducted with SB4 simulant sludge slurry:

- The CC + PF digestion method will result in reduced DWPF Lab analytical turnaround time over the PF only digestion method.

- The CC + PF digestion resulted in complete digestion of all forms of $\mathrm{Al}$ and the measured combined concentration of $\mathrm{Al}$ was nearly equal to that of the PF only method.

- Pursue a side-by-side development and comparison of the combined digestion method (DWPF CC plus PF of undissolved solids) using radioactive sludge.

- Perform periodic analyses (X-ray diffraction) on solids that may be in the DWPF CC analytical process digestion samples at DWPF to help further refine the digestion method. 
WSRC-STI-2007-00515

Revision 0

This page intentionally left blank 


\section{TABLE OF CONTENTS}

EXECUTIVE SUMMARY ............................................................................. vi

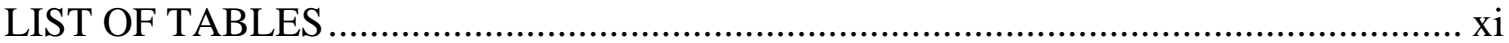

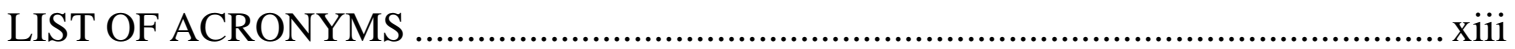

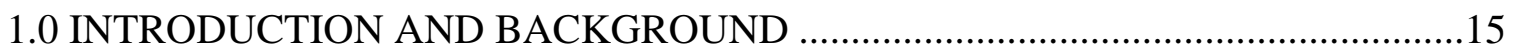

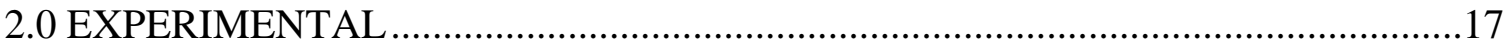

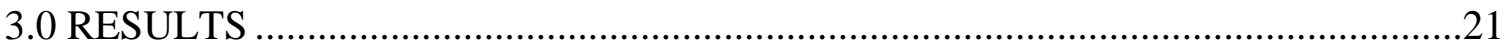

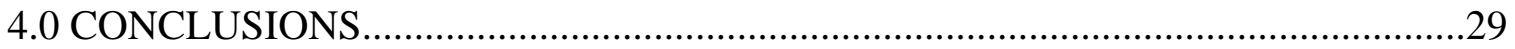

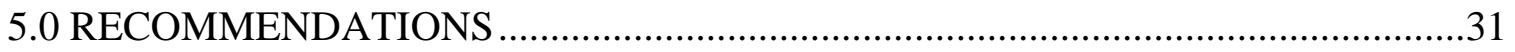

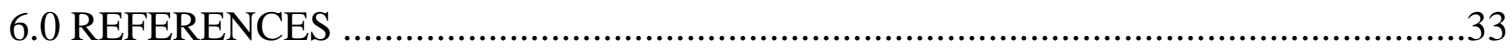

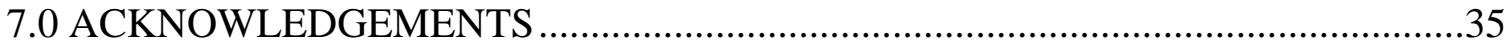

Appendix A - JMP One-Way Analysis Plots of ARG Digested by PF and DWPF CC ....37

Appendix B - JMP One-Way Analysis Plots of SB4 Simulant Digested by PF and

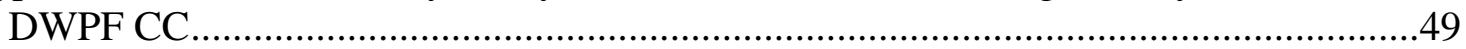

Appendix C - JMP One-Way Analysis Plots of SB4 spiked with Boehmite Digested by DWPF CC + PF and PF.

Appendix D - JMP One-Way Analysis Plots of ARG digested with Boehmite spiked SB4 simulant by DWPF CC + PF and PF. 
WSRC-STI-2007-00515

Revision 0

This page intentionally left blank 


\section{LIST OF TABLES}

Table 3.1 ICP-ES analysis results from digested (DWPF CC and PF) SB4 simulant sludge slurry and statistical comparison of the data. Values are presented on a wt \% dried solids basis.

Table 3.2 ICP-ES analysis results from digested (DWPF CC and PF) ARG samples and statistical comparison of the data. Values are presented on a wt \% dried solids basis.. 22

Table 3.3 Multi-element ICP-ES standard results. Standards were analyzed as part of the sample batch that included the samples in Table 3.1 and Table 3.2.

Table 3.4 ICP-ES analysis results from digested (DWPF Cold Chem Method + PF digestion of the undissolved solids in the DWPF Cold Chem Method solutions versus PF) SB4 simulant sludge slurry spiked with boehmite and statistical comparison of the data. Values are presented on a wt\% dried solids basis.

Table 3.5 ICP-ES analysis results of the undissolved/precipitated solids from the DWPF CC digestions of boemite spiked SB4 simulant sludge.

Table 3.6 ICP-ES analysis results from digested (DWPF CC + PF digestion of the undissolved solids in the DWPF CC Method solutions versus PF) ARG samples and statistical comparison of the data to the ARG reference value. Values are presented on a wt $\%$ dried solids basis.

Table 3.7 Multi-element ICP-ES standard results. Standards were analyzed as part of the sample batch that included he samples in Table 3.4 and Table 3.6.

Table 3.8 ICP-ES results from analysis of digested feldspar. Feldspar was digested in duplicate and in tandem with the samples listed in Table 3.6, Table 3.7 and Table 3.9. 28

Table 3.9 ICP-ES results from analysis of digested purified boehmite. Purified boehmite was digested in triplicate and in tandem with the samples listed in Table 3.6, Table 3.7 and Table 3.8... 
WSRC-STI-2007-00515

Revision 0

This page intentionally left blank 


\section{LIST OF ACRONYMS}

AD

ARG

CC

CXRD

DI

DOE

DWPF

ICP-ES

$\mathrm{PF}$

PS\&E

SB

SRAT

SRM

SRNL
Analytical Development

Analytical Reference Glass

Cold Chem Method

Contained X-ray Diffraction

De-Ionized

Department of Energy

Defense Waste Processing Facility

Inductively Coupled Plasma Emission Spectroscopy

Sodium Peroxide/Hydroxide Fusion

Process Science and Engineering

Sludge Batch

Slurry Receipt and Adjustment Tank

Standard Reference Material

Savannah River National Laboratory 
WSRC-STI-2007-00515

Revision 0

This page intentionally left blank 


\subsection{INTRODUCTION AND BACKGROUND}

Heavy-water reactors at the Savannah River Site were operated for approximately 30 years to produce nuclear materials for the nation's defense. Low temperature reactor operation allowed the use of Al-clad, Al-uranium (U) alloy fuel. At the end of the reactor cycle, and upon cooling, dissolution and separation of the components in this fuel produced an aqueous waste stream with a high concentration of Al. The aqueous waste was sent to H-Area tank farm where it was adjusted to prevent waste tank corrosion. The sludge from one of these tanks (Tank 11) was blended with the heel from Tank 7 (F-Area Tank) to produce the latest sludge batch feed Sludge Batch 4 (SB4) for the DWPF. ${ }^{5}$

Aluminum plays a direct role in vitrification chemistry. At moderate levels, $\mathrm{Al}$ assists in glass forming. At elevated levels, $\mathrm{Al}$ can increase the viscosity of the molten glass which can adversely impact the glass production rate and the volume of glass produced via limiting waste loading. ${ }^{3}$ In addition, an increased $\mathrm{Al}$ concentration may contribute to nepheline $\left(\mathrm{NaAlSiO}_{4}\right)$ formation as a devitrification product during canister cooling. ${ }^{5}$ To meet the Tank Farm needs for tank space, a caustic leaching step to reduce the $\mathrm{Al}$ levels for SB4 was not pursued but may be pursued for future DWPF sludge batches. Therefore, SB4 contains a much higher weight percent $\mathrm{Al}$ concentration than previous sludge batches. The aluminum present in SB4 is, in part, present as a mixture of gibbsite $\left[\alpha\right.$-aluminum trihydroxide, $\left.\alpha-\mathrm{Al}(\mathrm{OH})_{3}\right]$ and boehmite ( $\alpha$-aluminum oxyhydroxide, $\alpha$-AlOOH) in an unknown ratio. The $\mathrm{Al}$ hydroxide content in Tank 11, before blending with Tank 7, was estimated to be an 80:20 boehmite/gibbsite mixture. An additional complication arises as gibbsite to boehmite transformation may occur in the self-heating alkaline environment encountered in the high-level waste storage tanks. ${ }^{3}$

Experimental studies involving digestion of high-level waste at SRNL indicate boehmite has limited solubility in the acid mixture (DWPF Cold Chem Method (CC), $25 \mathrm{~mL} \mathrm{HNO}_{3}$ and $25 \mathrm{~mL} \mathrm{HF}$ ) used by the DWPF Lab to digest process control samples; gibbsite is soluble in the CC mixture. ${ }^{2}$ ICP-ES data from digested as-received Tank 51 SB4 radioactive sludge slurry and washed Tank 51 SB4 radioactive sludge slurry samples which were previously characterized indicate the difference in the aluminum concentration between the two digestions $\sim$ was $6 . \%\left(10.5 \mathrm{wt} \% \mathrm{Al}\right.$ on a dried solids basis measured in the $\mathrm{Na}_{2} \mathrm{O}_{2} / \mathrm{NaOH}$ fusion vs 9.85 $\mathrm{wt} \% \mathrm{Al}$ on a dried solids measured in the DWPF CC method) and $27 \%$ (16.4 wt\% Al on a dried solids basis vs $12.5 \mathrm{wt} \% \mathrm{Al}$ on a dried solids basis measured by the DWPF Cold Chem method) for the washed Tank 51 radioactive sludge slurry sample. Undissolved solids remained in the DWPF CC digestate solutions in each case. The undissolved solids in the as-received Tank 51 SB4 digestate solutions were determined to be boehmite $(\mathrm{AlO}(\mathrm{OH}))$, muscovite $(\mathrm{K}, \mathrm{Na})(\mathrm{Al}, \mathrm{Mg}, \mathrm{Fe})_{2}\left(\mathrm{Si}_{3.1} \mathrm{Al}_{0.9}\right) \mathrm{O}_{10}(\mathrm{OH})_{2}$, and silicon dioxide $\left(\mathrm{SiO}_{2}\right)$. The undissolved solids in the washed Tank 51 SB4 digestate solutions were determined to be potassium sodium aluminum fluoride $\left(\mathrm{K}_{2} \mathrm{NaAl}_{3} \mathrm{~F}_{12}\right)$, potassium aluminum fluoride $\left(\mathrm{K}_{2} \mathrm{AlF}_{5}\right)$, aluminum fluoride $\left(\mathrm{AlF}_{3}\right)$, and chiolite $\left(\mathrm{Na}_{5} \mathrm{Al}_{3} \mathrm{~F}_{14}\right)$. No undissolved solids remained in the $\mathrm{Na}_{2} \mathrm{O}_{2} / \mathrm{NaOH}$ fusion digestate solutions. ${ }^{2}$ The difference in the observed solubility is a kinetic phenomenon. Because Al plays such an important part in vitrification chemistry it is necessary to have a robust digestion method that will dissolve all forms of Al present in the radioactive sludge and dissolve precipitated species while not increasing the DWPF analytical lab turn-around-time. This report details experimental digestion studies performed on simulant sludge without boehmite and spiked with boehmite. Statistical comparisons of data generated from Inductively Coupled Plasma Emission Spectroscopy (ICP-ES) analysis of sample solutions from two different digestion schemes are presented for $\mathrm{Al}$ and the other elements that are analyzed by the DWPF Lab (16 elements in all), except $U$. 
WSRC-STI-2007-00515

Revision 0

This page intentionally left blank 


\title{
2.0 EXPERIMENTAL
}

\author{
Experimental Outline
}

M. E. Stone of Process Science and Engineering (PS\&E) provided SB4 simulant sludge for this study which contained $\mathrm{Al}$ hydroxide in the form of gibbsite. The experimental outline is pictorially represented below and a detailed description follows.

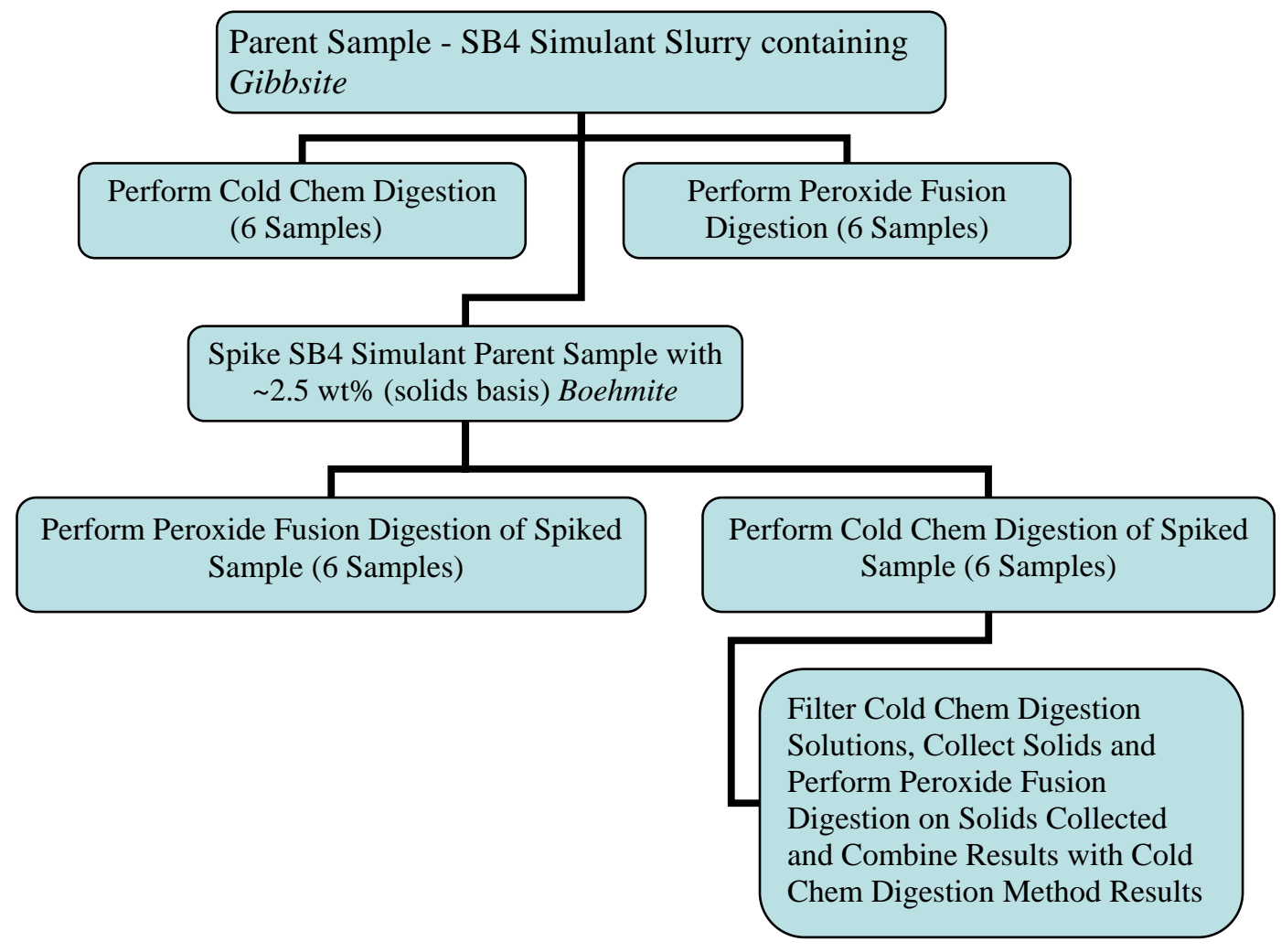

A portion of the parent SB4 slurry sample was dissolved using two digestion techniques (PF and CC) and the resulting solutions were analyzed by ICP-ES. The Al results from the PF digestion were used to represent the 'true' concentration of $\mathrm{Al}$ in the parent sample and used to calculate how much boehmite to add to the sample. Boehmite (0.9069 g) was spiked into $74.1318 \mathrm{~g}$ of SB4 simulant slurry (21.7 $\pm 0.2 \mathrm{wt}$ $\%$ solids) to increase the $\mathrm{Al}$ concentration of the sample by ca. $2.5 \%$. The calculated weight percent total solids in the SB4 spiked sample was 22.65 and the measured weight percent total solids in the sample was 22.55. This corresponds to $0.0534 \mathrm{~g}$ of boehmite/g of solids. Boehmite is $44.98 \%$ wt \% Al. A portion of the spiked sample was digested using two digestions techniques (PF and $\mathrm{CC}$ ). The PF digestion completely dissolved the entire sample. However, solids remained in the CC digestion solutions and were isolated by filtration, dried and subjected to a PF digestion. All sets of samples were analyzed by ICP-ES. The ICP-ES results of the PF digestion of the spiked samples were compared to the sum of the ICP-ES results of the CC digestion and the extra PF digestion which was necessary to dissolve the solids remaining in the $\mathrm{CC}$ digestion solutions. 


\section{Digestion of SB4 Sludge Slurry Parent Sample}

The initial PF digestion of SB4 simulant sludge slurry containing $\mathrm{Al}$ in the form of gibbsite was performed according to ADS Procedure 2502 by adding 1.1 g of SB4 simulant sludge $(21.7 \pm 0.2 \mathrm{wt} \%$ solids) to six separate zirconium (Zr) crucibles. The slurry in the crucibles was dried until two consecutive weighings varied by $\pm 0.01 \mathrm{~g}$ or less. The crucibles were cooled, and $\sim 1.5 \mathrm{~g}$ of sodium peroxide $\left(\mathrm{Na}_{2} \mathrm{O}_{2}\right)$ and $\sim 1.0$ gram of sodium hydroxide $(\mathrm{NaOH})$ were added to each. The mixtures were heated to $675^{\circ} \mathrm{C}$ and maintained at the temperature for $10 \mathrm{~min}$. The resulting flux in each crucible was allowed to cool and then dissolved by the addition of deionized (DI) water and $25 \mathrm{~mL}$ of $\mathrm{HNO}_{3}$. Upon dilution the solutions were cloudy with a faint reddish-brown color. The addition of 3 drops of $30 \%$ hydrogen peroxide $\left(\mathrm{H}_{2} \mathrm{O}_{2}\right)$ clarified the solutions. The samples were diluted to $250 \mathrm{~mL}$. For quality control, three Analytical Reference Glass (ARG) standards ( $\sim .25 \mathrm{~g})$ were digested in a manner similar to that for the SB4 slurry. The ARG samples and one multi-element ICP standard were submitted for analysis by ICP-ES along with the digested SB4 slurry samples.

The DWPF CC digestions of SB4 simulant sludge slurry were performed by adding $\sim 4.1 \mathrm{~g}$ of simulant sludge ( $21.7 \pm 0.2 \mathrm{wt} \%$ solids, 6 samples were prepared) to a $125 \mathrm{~mL}$ plastic bottle followed by $25 \mathrm{~mL}$ of concentrated HF. The solution was stirred for $1 \mathrm{hr}, 25 \mathrm{~mL}$ of concentrated $\mathrm{HNO}_{3}$ was added, and the solution was further stirred for $30 \mathrm{~min}$. The resulting solutions were serially diluted to an effective volume of $5000 \mathrm{~mL}$. For quality control, three ARG standards ( 1 g) were digested in a manner similar to that of the SB4 slurry. The ARG samples and one multi-element ICP standard were submitted for analysis by ICP-ES along with the digested SB4 slurry samples.

\section{Digestion of SB4 Sludge Slurry Spiked Sample}

PF digestion of the spiked SB4 simulant sludge was performed in a manner similar to that previously noted. The resulting solutions were submitted for analysis by ICP-ES.

DWPF CC digestions of boehmite spiked SB4 simulant sludge were performed in a manner similar to that above. Approximately $4.2 \mathrm{~g}$ of simulant sludge ( $22.55 \pm 0.05 \mathrm{wt} \%$ solids) was added to each of six 125 $\mathrm{mL}$ plastic bottles followed by $25 \mathrm{~mL}$ of concentrated HF. Each solution was stirred for $1 \mathrm{hr}$, then $25 \mathrm{~mL}$ of $\mathrm{HNO}_{3}$ was added, and the solution was stirred for $30 \mathrm{~min}$. The samples were then diluted to $250 \mathrm{~mL}$ with DI water in a volumetric flask. Every diluted solution had solids remaining at the bottom of the volumetric flask. The solutions were filtered through separate 0.2-micron nylon filters with predetermined weights and the solids that were collected were dried in an oven at $110^{\circ} \mathrm{C}$ for $2 \mathrm{hr}$. Another weight of each filter and the solids collected was obtained, and the weight of the solids on each filter determined. Approximately $5 \mathrm{~mL}$ of the filtered solution was further diluted to $100 \mathrm{~mL}$ in a volumetric flask using DI water. The solids collected on the filter and the filter were heated to $675^{\circ} \mathrm{C}$ for $10 \mathrm{~min}$ (to oxidize the nylon filter) in a Zr crucible. The remaining solids were subjected to a PF digestion. Each sample solution was analyzed by ICP-ES separately. It is conceivable to combine the DWPF CC digestion solutions and the digestion solutions resulting from the filtration with PF digestion of the solids collected from the former digestion solutions for analysis.

\section{Digestion of Nylon Filters, Soda Feldspar and Boehmite}

Three nylon filters were subjected to $675^{\circ} \mathrm{C}$ in $\mathrm{Zr}$ crucibles for $10 \mathrm{~min}$ in order to determine the impact of the nylon filters on the experiments with the SB4 simulant. The experiments were performed in the following manner. Three 0.2-micron nylon filters were placed into separate weighed Zr crucibles, and they were heated to $675^{\circ} \mathrm{C}$ for 10 minutes. The filters oxidized completely and difference between the starting weight of the $\mathrm{Zr}$ crucible and the final weight of the $\mathrm{Zr}$ crucible + filter after heating was negligible. 
WSRC-STI-2007-00515

Revision 0

Three soda feldspar samples ( 0.3 g) containing 20.5 wt\% Al and three boehmite samples ( 0.05 g) were heated to $675^{\circ} \mathrm{C}$ in a $\mathrm{Zr}$ crucible with a nylon filter. The filter underwent complete combustion. The remaining white powder in each crucible was subjected to a PF digestion in the manner previously described. The average recovery of $\mathrm{Al}$ from PF digestion of boehmite was $\sim 96 \%$. The average recovery of $\mathrm{Al}$ from $\mathrm{PF}$ digestion of feldspar was also 96\%. 
WSRC-STI-2007-00515

Revision 0

This page intentionally left blank 


\subsection{RESULTS}

The experimental results (shown for the 16 elements for which DWPF analyzes) from the initial digestion and ICP-ES analysis of the SB4 simulant parent sample are shown in Table 3.1. Six sub-samples of the parent sample were digested by each method (CC and PF) along with 3 ARG samples. The ICP-ES analysis results of the ARG standards are shown in Table 3.1.

Table 3.1 ICP-ES analysis results from digested (DWPF CC and PF) SB4 simulant sludge slurry and statistical comparison of the data. Values are presented on a wt \% dried solids basis.

\begin{tabular}{|c|c|c|c|c|c|c|}
\hline Element & $\begin{array}{c}\text { Elemental Wt } \\
\text { \% from } \\
\text { DWPF CC } \\
\text { Digestion* }\end{array}$ & \% RSD & Element & $\begin{array}{c}\text { Elemental Wt } \\
\text { \% from PF } \\
\text { Digestion * }\end{array}$ & \% RSD & $\begin{array}{c}\text { Statistically } \\
\text { Different } \\
\text { Means (at a } \\
5 \% \\
\text { significance } \\
\text { level) }\end{array}$ \\
\hline $\mathrm{Al}$ & $8.52 \mathrm{E}+00$ & $1.5 \mathrm{E}+00$ & $\mathrm{Al}$ & $8.21 \mathrm{E}+00$ & $1.4 \mathrm{E}+00$ & Yes \\
\hline $\mathrm{B}$ & $<7.12 \mathrm{E}-02$ & $\mathrm{NA}$ & $\mathrm{B}$ & $4.01 \mathrm{E}-02$ & $1.2 \mathrm{E}+01$ & NA \\
\hline $\mathrm{Ca}$ & $1.09 \mathrm{E}+00$ & $1.5 \mathrm{E}+01$ & $\mathrm{Ca}$ & $1.25 \mathrm{E}+00$ & $1.9 \mathrm{E}+00$ & Yes \\
\hline $\mathrm{Cr}$ & $1.52 \mathrm{E}-02$ & $1.9 \mathrm{E}+01$ & $\mathrm{Cr}$ & $1.22 \mathrm{E}-01$ & $1.1 \mathrm{E}+00$ & Yes \\
\hline $\mathrm{Cu}$ & $5.53 \mathrm{E}-02$ & $1.6 \mathrm{E}+01$ & $\mathrm{Cu}$ & $4.99 \mathrm{E}-02$ & $2.4 \mathrm{E}+00$ & No \\
\hline $\mathrm{Fe}$ & $1.60 \mathrm{E}+01$ & $1.1 \mathrm{E}+00$ & $\mathrm{Fe}$ & $1.54 \mathrm{E}+01$ & $1.2 \mathrm{E}+00$ & Yes \\
\hline $\mathrm{Li}$ & $<2.05 \mathrm{E}-02$ & $\mathrm{NA}$ & $\mathrm{Li}$ & $<4.16 \mathrm{E}-03$ & $\mathrm{NA}$ & NA \\
\hline $\mathrm{K}$ & $1.26 \mathrm{E}+00$ & $2.8 \mathrm{E}+01$ & $\mathrm{~K}$ & $1.14 \mathrm{E}+00$ & $4.5 \mathrm{E}+00$ & No \\
\hline $\mathrm{Mg}$ & $6.56 \mathrm{E}-01$ & $8.2 \mathrm{E}+00$ & $\mathrm{Mg}$ & $6.29 \mathrm{E}-01$ & $1.8 \mathrm{E}+00$ & No \\
\hline $\mathrm{Mn}$ & $4.08 \mathrm{E}+00$ & $1.2 \mathrm{E}+00$ & $\mathrm{Mn}$ & $3.90 \mathrm{E}+00$ & $1.3 \mathrm{E}+00$ & Yes \\
\hline $\mathrm{Na}$ & $1.12 \mathrm{E}+01$ & $1.2 \mathrm{E}+00$ & $\mathrm{Na}$ & $\mathrm{NA}$ & $\mathrm{NA}$ & NA \\
\hline $\mathrm{Ni}$ & $2.23 \mathrm{E}+00$ & $1.2 \mathrm{E}+00$ & $\mathrm{Ni}$ & $2.18 \mathrm{E}+00$ & $1.3 \mathrm{E}+00$ & Yes \\
\hline $\mathrm{Si}$ & $\mathrm{NA}$ & $\mathrm{NA}$ & $\mathrm{Si}$ & $9.14 \mathrm{E}-01$ & $1.4 \mathrm{E}+00$ & NA \\
\hline $\mathrm{Ti}$ & $1.64 \mathrm{E}-02$ & $7.2 \mathrm{E}+00$ & $\mathrm{Ti}$ & $1.63 \mathrm{E}-02$ & $4.1 \mathrm{E}+00$ & No \\
\hline $\mathrm{U} \wedge$ & $\mathrm{NA}$ & $\mathrm{NA}$ & $\mathrm{NA}$ & $\mathrm{NA}$ & $\mathrm{NA}$ & NA \\
\hline $\mathrm{Zr}$ & $1.81 \mathrm{E}-01$ & $2.9 \mathrm{E}+00$ & $\mathrm{Zr}$ & $\mathrm{NA}$ & $\mathrm{NA}$ & NA \\
\hline $\mathrm{Na}$ & & & & & \\
\hline
\end{tabular}

*Six samples were digested by each method and analyzed by ICP-ES. ${ }^{\#} \%$ RSD = percent relative standard deviation.

$\wedge$ Uranium is not present in the simulant sludge.

A statistical comparison of the ICP-ES data was performed by Tommy Edwards (Statistical Consulting) using JMP software ${ }^{6}$ (see appendix B). The JMP software compares sets of data and reports a numerical value. Comparison of the reported value versus a known threshold value determines if the means are statistically different. In this report, for ease of reading, 'yes' and 'no' are used to designate if data have statistically different means at the $5 \%$ significance level. The average concentrations of nearly every element are lower in the PF digestion as compared to the DWPF CC digestion, except Ca. The results of the statistical comparison between the means of the PF digestion and the CC digestion indicate statistically different means (at the 5\% confidence level) for $\mathrm{Al}, \mathrm{Ca}, \mathrm{Cr}, \mathrm{Fe}, \mathrm{Mn}$, and $\mathrm{Ni}$. The reason for the lower concentrations observed in the PF results is unclear. It should be noted that a small absolute difference between two average values may be statistically different (in this case at the $5 \%$ significance level) if there is a small variation between each of their measured values as is the case for Al. However, even if a statistical difference exists between two numbers that have a small absolute difference, there may not be a practical difference in the way the results are evaluated in a process lab. Calcium is a contaminant in the PF reagents and so the higher average concentration measured by ICP-ES in the PF samples was expected. Chromium is present but at a very low concentration, which may help to explain 
the statistical difference. Boron (B), lithium (Li), sodium (Na), silicon (Si), U, and zirconium (Zr) were not evaluated during the statistical analysis. The $\mathrm{B}$ concentration in the solutions resulting from digestion of the simulant sludge using the DWPC CC method was below the detection limit of the ICP-ES. The Li concentration was below the ICP-ES detection limit in both digestion solutions submitted. Sodium is part of the fusion reagents and $\mathrm{Si}$ is etched from the glassware of the ICP-ES instrument during analysis. Uranium is not present in the simulant sludge and the fusion is performed in a $\mathrm{Zr}$ crucible, a source of $\mathrm{Zr}$ contamination.

A statistical comparison of the ICP-ES data from tandem digestions (CC and PF) of ARG standards revealed fewer statistical differences overall (see Appendix A). However, statistical differences in the measured ICP-ES concentrations were seen for Al, Ca, Cr, and Mn.

Two multi-element ICP standards were submitted and analyzed by ICP-ES along with the samples and ARG standards. The multi-element standard contains Al, B, Fe, Li, K, Si and Na. One standard is analyzed within the first few samples of the sample batch and the other is analyzed at the end of the sample batch. The results from an analysis of the multi-element standards are summarized in Table 3.3.

Table 3.2 ICP-ES analysis results from digested (DWPF CC and PF) ARG samples and statistical comparison of the data. Values are presented on a wt \% dried solids basis.

\begin{tabular}{|c|c|c|c|c|c|c|c|}
\hline Element & $\begin{array}{c}\text { Elemental Wt } \\
\% \text { from } \\
\text { DWPF CC } \\
\text { Digestion * }\end{array}$ & $\% \mathrm{RSD}^{\#}$ & $\begin{array}{c}\text { Elemental } \mathrm{Wt} \\
\% \text { from PF } \\
\text { Digestion * }\end{array}$ & $\% \mathrm{RSD}^{\#}$ & $\begin{array}{c}\text { Statistically } \\
\text { Different } \\
\text { Means } \\
\text { (at a 5\% } \\
\text { significance } \\
\text { level) } \\
\end{array}$ & $\begin{array}{c}\text { DWPF CC } \\
\text { Digestion } \\
\text { Result - Ratio } \\
\text { to True Value }\end{array}$ & $\begin{array}{c}\text { PF } \\
\text { Digestion } \\
\text { Result - Ratio } \\
\text { to True Value }\end{array}$ \\
\hline $\mathrm{Al}$ & $2.27 \mathrm{E}+00$ & $2.1 \mathrm{E}+00$ & $2.38 \mathrm{E}+00$ & $1.6 \mathrm{E}+00$ & Yes & 0.91 & 0.95 \\
\hline $\mathrm{B}$ & $2.80 \mathrm{E}+00$ & $5.3 \mathrm{E}+00$ & $2.67 \mathrm{E}+00$ & $1.7 \mathrm{E}+00$ & No & 1.04 & 0.99 \\
\hline $\mathrm{Ca}$ & 9.96E-01 & $2.7 \mathrm{E}+00$ & $1.13 \mathrm{E}+00$ & $2.5 \mathrm{E}+00$ & Yes & 0.98 & 1.11 \\
\hline $\mathrm{Cr}$ & 6.97E-02 & $2.7 \mathrm{E}+00$ & 6.43E-02 & $2.8 \mathrm{E}+00$ & Yes & 1.09 & 1.00 \\
\hline $\mathrm{Cu}$ & $<4.73 \mathrm{E}-02$ & NA & $<8.64 \mathrm{E}-03$ & NA & NA & NA & NA \\
\hline $\mathrm{Fe}$ & $9.85 \mathrm{E}+00$ & $1.6 \mathrm{E}+00$ & $9.61 \mathrm{E}+00$ & $1.6 \mathrm{E}+00$ & No & 1.01 & 0.98 \\
\hline $\mathrm{Li}$ & $1.41 \mathrm{E}+00$ & $1.8 \mathrm{E}+00$ & $1.37 \mathrm{E}+00$ & 8.4E-01 & No & 0.95 & 0.92 \\
\hline $\mathrm{K}$ & $1.80 \mathrm{E}+00$ & $1.9 \mathrm{E}+01$ & $2.26 \mathrm{E}+00$ & $3.3 \mathrm{E}+00$ & No & 0.80 & 1.00 \\
\hline $\mathrm{Mg}$ & 4.68E-01 & $2.8 \mathrm{E}+00$ & 4.80E-01 & $3.5 \mathrm{E}+00$ & No & 0.90 & 0.92 \\
\hline Mn & $1.43 \mathrm{E}+00$ & $1.5 \mathrm{E}+00$ & $1.37 \mathrm{E}+00$ & $1.5 \mathrm{E}+00$ & Yes & 0.98 & 0.94 \\
\hline $\mathrm{Na}$ & $9.86 \mathrm{E}+00$ & $1.3 \mathrm{E}+00$ & NA & NA & NA & 1.16 & NA \\
\hline $\mathrm{Ni}$ & 8.21E-01 & 8.8E-01 & 7.97E-01 & $1.9 \mathrm{E}+00$ & No & 0.99 & 0.96 \\
\hline $\mathrm{Si}$ & NA & NA & $2.30 \mathrm{E}+01$ & $1.3 \mathrm{E}+00$ & NA & NA & 1.03 \\
\hline $\mathrm{Ti}$ & 6.83E-01 & $1.3 \mathrm{E}+00$ & 6.82E-01 & $1.0 \mathrm{E}+00$ & No & 0.99 & 0.99 \\
\hline $\mathrm{U}^{\wedge}$ & NA & NA & NA & NA & NA & NA & NA \\
\hline $\mathrm{Zr}$ & 8.83E-02 & $6.1 \mathrm{E}+00$ & 2.65E-02 & $2.3 \mathrm{E}+01$ & NA & 0.92 & NA \\
\hline
\end{tabular}

*Three samples were digested by each method and analyzed by ICP-ES. ${ }^{\#} \%$ RSD $=$ percent relative standard deviation.

$\wedge$ Uranium is not present in the simulant sludge. 
WSRC-STI-2007-00515

Revision 0

Table 3.3 Multi-element ICP-ES standard results. Standards were analyzed as part of the sample batch that included the samples in Table 3.1 and Table 3.2.

\begin{tabular}{|c|c|c|c|c|c|c|c|c|c|}
\hline & & \multicolumn{4}{|c|}{ DWPF CC } & \multicolumn{4}{c|}{ PF } \\
\hline $\begin{array}{c}\text { Element } \\
\text { in ICP- } \\
\text { ES Std }\end{array}$ & $\begin{array}{c}\text { Reference } \\
\text { Value }\end{array}$ & $\begin{array}{c}\text { Result } \\
(\mathrm{mg} / \mathrm{L}) \\
\text { Run } 1^{*}\end{array}$ & Delta & $\begin{array}{c}\text { Result } \\
(\mathrm{mg} / \mathrm{L}) \\
\text { Run 2^ }\end{array}$ & Delta & $\begin{array}{c}\text { Result } \\
(\mathrm{mg} / \mathrm{L}) \\
\text { Run } 1^{*}\end{array}$ & Delta & $\begin{array}{c}\text { Result } \\
(\mathrm{mg} / \mathrm{L}) \\
\text { Run } 1^{\wedge}\end{array}$ & Delta \\
\hline $\mathrm{Al}$ & 4.0 & 3.9 & -2.5 & 3.9 & -3.8 & 3.81 & -4.8 & 3.82 & -4.5 \\
\hline $\mathrm{B}$ & 20.0 & 20.0 & 0 & 20.0 & 0 & 20.1 & 0.5 & 20.1 & 0.5 \\
\hline $\mathrm{Fe}$ & 4.0 & 4.1 & 1.5 & 3.97 & -0.8 & 4.03 & 0.8 & 4.00 & 0 \\
\hline $\mathrm{Li}$ & 10.0 & 9.6 & -3.7 & 9.39 & -6.1 & 9.54 & -4.6 & 9.43 & -5.7 \\
\hline $\mathrm{K}$ & 10.0 & 8.7 & -13.2 & 7.77 & -22.3 & 8.39 & -16.1 & 10.5 & 5 \\
\hline $\mathrm{Si}$ & 50.0 & NA & NA & NA & NA & 51.8 & 3.6 & 51.7 & 3.4 \\
\hline $\mathrm{Na}$ & 81.0 & 95.6 & 18.0 & 97.3 & 20.1 & NA & NA & NA & NA \\
\hline
\end{tabular}

*Multi-element standard analyzed within the first few samples of the batch. $\wedge$ Multi-element standard analyzed at the end of the sample batch.

The next step in the experimental scheme was to add $~ 2.5 \mathrm{wt} \% \mathrm{Al}$, in the form of boehmite, to the parent sample. Although gibbsite is sufficiently soluble in acid media and the average Al concentration in the solutions generated by the DWPF CC method was higher than the Al concentration in the PF solutions, the average $\mathrm{PF} \mathrm{Al}$ value was used as the baseline $\mathrm{Al}$ concentration. The parent sample was then spiked with boehmite and dissolved by performing a PF digestion and the DWPF CC method. The solutions resulting from the PF digestion were clear and did not contain visible solids. However, the solutions resulting from the initial dilution of the acid mixture used in the DWPF CC method contained visible solids in all six cases. The solutions were filtered using a 0.2-micron nylon filter prior to serial dilution of the sample. The solids that were collected on the nylon filter and the filter itself were dried in the oven at $110{ }^{\circ} \mathrm{C}$ for $2 \mathrm{hr}$. The filters along with the solids were transferred to $\mathrm{Zr}$ crucibles, heated to $675{ }^{\circ} \mathrm{C}$ and maintained at that temperature for ten minutes. The Zr crucibles were removed from the oven and cooled to room temperature. The residues left in the $\mathrm{Zr}$ crucibles were subjected to a PF digestion as described in the experimental section. The experimentally measured concentrations from the DWPF CC method plus the PF digestion of the resulting solids were combined to yield the final result. The results from ICP-ES analysis of samples generated from digestion of boehmite spiked simulant sludge are presented in Table 3.4 
Table 3.4 ICP-ES analysis results from digested (DWPF Cold Chem Method + PF digestion of the undissolved solids in the DWPF Cold Chem Method solutions versus PF) SB4 simulant sludge slurry spiked with boehmite and statistical comparison of the data. Values are presented on a wt\% dried solids basis.

\begin{tabular}{|c|c|c|c|c|c|c|}
\hline Element & $\begin{array}{c}\text { Elemental Wt \% from } \\
\text { DWPF CC Digestion } \\
+ \text { PF } \\
\text { Digestion* }\end{array}$ & $\% \mathrm{RSD}^{\#}$ & $\begin{array}{l}\text { Elemental Wt } \\
\% \text { from PF } \\
\text { Digestion } *\end{array}$ & $\% \mathrm{RSD}^{\#}$ & \begin{tabular}{|c|} 
Statistically \\
Different Means (at a \\
5\% significance \\
level)
\end{tabular} & $\begin{array}{c}\text { Ratio (PF + CC } \\
\text { Average } \\
\text { Concentration to PF } \\
\text { Average } \\
\text { Concentration) } \\
\end{array}$ \\
\hline $\mathrm{Al}$ & $1.01 \mathrm{E}+01$ & 4.3E-01 & $1.07 \mathrm{E}+01$ & 9.2E-01 & Yes & 0.94 \\
\hline $\mathrm{B}$ & 7.50E-02 & $1.1 \mathrm{E}+02$ & 4.60E-02 & $1.8 \mathrm{E}+01$ & No & 1.95 \\
\hline $\mathrm{Ca}$ & 9.95E-01 & $1.9 \mathrm{E}+01$ & $1.29 \mathrm{E}+00$ & $3.0 \mathrm{E}+00$ & Yes & 0.77 \\
\hline $\mathrm{Cr}$ & $1.22 \mathrm{E}-01$ & $2.0 \mathrm{E}+01$ & $1.25 \mathrm{E}-01$ & $1.3 \mathrm{E}+00$ & No & 0.98 \\
\hline $\mathrm{Cu}$ & 4.39E-02 & $8.4 \mathrm{E}+01$ & 4.30E-02 & 4.3E-02 & No & 1.22 \\
\hline $\mathrm{Fe}$ & $1.51 \mathrm{E}+01$ & $1.9 \mathrm{E}-01$ & $1.53 \mathrm{E}+01$ & 3.6E-01 & No & 0.99 \\
\hline $\mathrm{Li}$ & 8.12E-03 & $2.4 \mathrm{E}+02$ & $<9.00 \mathrm{E}-03$ & NA & NA & NA \\
\hline $\mathrm{K}$ & $1.97 \mathrm{E}-01$ & $2.0 \mathrm{E}+02$ & $1.15 \mathrm{E}+00$ & $1.1 \mathrm{E}+01$ & Yes & 0.26 \\
\hline $\mathrm{Mg}$ & 5.92E-01 & $6.6 \mathrm{E}+00$ & 6.47E-01 & $9.4 \mathrm{E}+01$ & Yes & 0.92 \\
\hline $\mathrm{Mn}$ & $3.91 \mathrm{E}+00$ & $2.6 \mathrm{E}+00$ & $3.95 \mathrm{E}+00$ & $4.1 \mathrm{E}+01$ & No & 0.99 \\
\hline $\mathrm{Na}$ & $8.33 \mathrm{E}+00$ & $1.4 \mathrm{E}+00$ & NA & NA & NA & NA \\
\hline $\mathrm{Ni}$ & $2.16 \mathrm{E}+00$ & $1.8 \mathrm{E}+00$ & $2.15 \mathrm{E}+00$ & $3.8 \mathrm{E}-01$ & No & 1.00 \\
\hline Si & NA & NA & 8.35E-01 & 8.9E-01 & NA & NA \\
\hline $\mathrm{Ti}$ & 2.9E-02 & $1.9 \mathrm{E}+02$ & $1.73 \mathrm{E}-02$ & $6.3 \mathrm{E}+01$ & No & 1.68 \\
\hline $\mathrm{U}^{\wedge}$ & NA & NA & NA & NA & NA & NA \\
\hline $\mathrm{Zr}$ & 1.85E-01 & $1.1 \mathrm{E}+01$ & NA & NA & NA & NA \\
\hline
\end{tabular}

*Six samples were digested by each method and analyzed by ICP-ES. ${ }^{{ }^{*}} \%$ RSD = percent relative standard deviation.

$\wedge$ Uranium is not present in the simulant sludge.

As seen in Table 3.4 the difference in the ICP-ES measured and averaged values for $\mathrm{Al}, \mathrm{Ca}, \mathrm{K}$ and $\mathrm{Mg}$ are statistically different at the $5 \%$ significance level. There does not appear to be a low bias between data from each digestion method compared to the results in Table 3.1. Lithium was below the detection limit in one case, $\mathrm{Na}$ is part of the fusion reagents, and $\mathrm{Si}$ is etched from the glassware of the ICP-ES instrument; therefore these elements were not evaluated in the statistical comparison. As noted in Table 3.4 fewer elements had a large enough difference in the mean values to result in a statistically significant difference. However, a larger spread in the data was seen for the experimentally obtained concentrations from the CC+PF digestion, see Appendix C.

The present set of experiments provided us the opportunity to examine the elemental make-up of the undissolved and/or precipitated solids from the DWPF CC digestion of the simulant sludge. Several elements were detected upon ICP-ES analysis of the filter that was digested by PF (containing undissolved and/or precipitated solids from the DWPF CC digestions) and are shown in Table 3.5.

The elements present in the filtered and undissolved solids include $\mathrm{Al}, \mathrm{Ca}, \mathrm{Cr}, \mathrm{Fe}, \mathrm{K}, \mathrm{Mg}, \mathrm{Mn}, \mathrm{Ni}$ and $\mathrm{Ti}$. Many of these metals are most likely counterions of a fluoride salt formed by precipitation with such a large amount of fluoride available in the digestions. Alternately some species may be like boehmite in the sense that they are kinetically slow to dissolve in acid media. Previous work involving CC digestions of both radioactive and non-radioactive sludge found $\mathrm{Al}, \mathrm{Fe}, \mathrm{K}, \mathrm{Mg}, \mathrm{Na}, \mathrm{Si}$ and $\mathrm{Zr}$ in undissolved or precipitated solids when analyzed using $x$-ray. The species previously identified were potassium sodium aluminum fluoride $\left(\mathrm{K}_{2} \mathrm{NaAl}_{3} \mathrm{~F}_{12}\right)$, potassium aluminum fluoride $\left(\mathrm{K}_{2} \mathrm{AlF}_{5}\right)$, aluminum fluoride $\left(\mathrm{AlF}_{3}\right)$, chiolite $\left(\mathrm{Na}_{5} \mathrm{Al}_{3} \mathrm{~F}_{14}\right)$, muscovite $(\mathrm{K}, \mathrm{Na})(\mathrm{Al}, \mathrm{Mg}, \mathrm{Fe})_{2}\left(\mathrm{Si}_{3.1} \mathrm{Al}_{0.9}\right)$, and other mixed metal aluminum fluorides such as $\mathrm{FeZrF}_{6}$ and $\mathrm{Na}_{2} \mathrm{FeAlF}_{7}$. 
Table 3.5 contains the total amount of solids present in the six original samples to undergo the DWPF CC digestion, the amount of undissolved or precipitated solids recovered by filtration of the digestion solutions, the amount of each element (cations only) present in the undissolved or precipitated solids, the percent of the undissolved or precipitated solids that is $\mathrm{Al}$, and the percent of $\mathrm{Al}$ that is from boehmite which was spiked into the sample. The percent $\mathrm{Al}$ in the undissolved solids from boehmite was calculated by determining the amount of boehmite present per gram of sludge solids and dividing the weight of $\mathrm{Al}$ measured from the PF digestion of undissolved/precipitated solids from the DWPF CC method digestions by the calculated amount of $\mathrm{Al}$ from boehmite spiked into the parent sample. In each case, more than $80 \%$ of the $\mathrm{Al}$ recovered was from boehmite. X-ray diffraction data were not obtained on any portion of the insoluble/precipitated solids.

Table 3.5 ICP-ES analysis results of the undissolved/precipitated solids from the DWPF CC digestions of boemite spiked SB4 simulant sludge.

\begin{tabular}{|c|c|c|c|c|c|c|}
\hline Sample \# & 1 & 2 & 3 & 4 & 5 & 6 \\
\hline \multicolumn{7}{|c|}{ Amount of Solids in Original DWPF CC Digestions } \\
\hline (g) & 0.905 & 0.911 & 0.920 & 0.927 & 0.940 & 0.903 \\
\hline \multicolumn{7}{|c|}{ Amount of Undissolved or Precipitated Solids in DWPF CC Digestions Recovered by Filtration } \\
\hline (g) & 0.1323 & 0.1170 & 0.1268 & 0.1211 & 0.1377 & 0.1145 \\
\hline \multicolumn{7}{|c|}{$\begin{array}{l}\text { Amount of Each Element in Undissolved or Precipitated Solids in DWPF CC Digestions (mg) Determined by ICP-ES } \\
\text { Analysis }\end{array}$} \\
\hline $\mathrm{Al}(\mathrm{mg})$ & 27.0 & 20.2 & 24.0 & 21.1 & 23.7 & 21.9 \\
\hline $\mathrm{Ca}(\mathrm{mg})$ & 7.3 & 5.8 & 6.4 & 6.5 & 6.6 & 6.6 \\
\hline $\mathrm{Cr}(\mathrm{mg})$ & 1.1 & 1.0 & 1.0 & 1.0 & 1.1 & 1.0 \\
\hline Fe (mg) & 3.2 & 2.2 & 2.7 & 2.3 & 2.5 & 2.2 \\
\hline $\mathrm{K}(\mathrm{mg})$ & 0.6 & 0.4 & $<\mathrm{MDL}$ & $<\mathrm{MDL}$ & 0.5 & $<\mathrm{MDL}$ \\
\hline $\mathrm{Mg}(\mathrm{mg})$ & 5.4 & 3.8 & 4.7 & 4.4 & 4.5 & 4.4 \\
\hline Mn (mg) & 2.8 & 2.0 & 2.5 & 2.1 & 2.2 & 2.0 \\
\hline $\mathrm{Ni}(\mathrm{mg})$ & 0.1 & 0.04 & 0.1 & 0.04 & 0.1 & 0.05 \\
\hline $\mathrm{Ti}(\mathrm{mg})$ & 0.03 & 0.02 & 0.02 & 0.03 & 0.03 & 0.03 \\
\hline Sum (mg) & 47.4 & 35.5 & 41.4 & 37.4 & 41.4 & 38.1 \\
\hline $\begin{array}{c}\% \text { of Al in } \\
\text { Undissolved/Precipitated } \\
\text { Solids }\end{array}$ & 56.9 & 57.1 & 57.9 & 56.3 & 57.2 & 57.4 \\
\hline $\begin{array}{l}\% \text { of Al from Boehmite in } \\
\text { solids (assuming all of it is } \\
\text { insoluble) }\end{array}$ & 84.1 & 112.8 & 96.3 & 110.3 & 99.5 & 103.6 \\
\hline
\end{tabular}

Statistically significant differences in concentration were noted in Table 3.4 for $\mathrm{Al}, \mathrm{Ca}, \mathrm{K}$ and $\mathrm{Mg}$ - all of which are seen in the solids recovered from filtration of the DWPF CC digestion solutions. However, it is difficult to assess the error associated with performing sequential digestions of material; therefore, the data were re-evaluated with the help of another statistical comparison for $\mathrm{Al}$. The Al data from the PF digestion were compared to the average and upper and lower bounds (obtained by adding the standard deviation to the average concentration of six samples or subtracting the standard deviation from the average concentration) of data obtained from the DWPF CC plus the PF digestions. This comparison gives a more complete picture of the variability associated with multiple digestions on the same material (Figure 3.1). 
Figure 3.1 Statistical comparison of the ICP-ES measured upper and lower bounds (percent relative standard deviation) of SB4 simulant sludge slurry spiked with boehmite digested by the DWPF CC + PF digestion of the undissolved solids in the DWPF CC solutions versus PF)

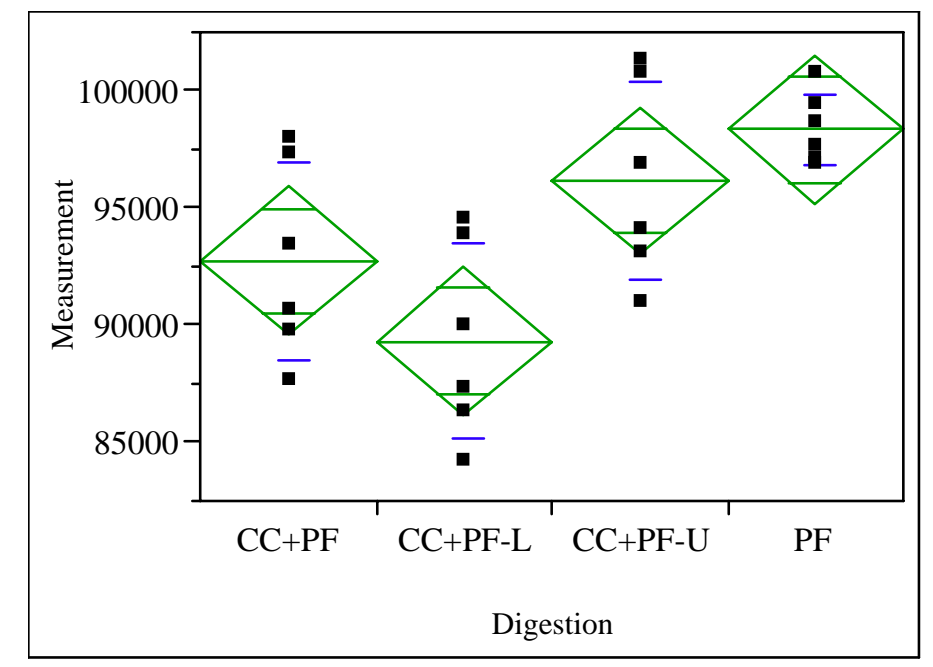

The lower concentration bound and the average concentration range of $\mathrm{Al}$ from the $\mathrm{CC}+\mathrm{PF}$ experiments are statistically different at the 5\% significance level from the PF only digestion. However, the upper concentration range of $\mathrm{Al}$ from the $\mathrm{CC}+\mathrm{PF}$ digestions and the $\mathrm{PF}$ digestion only are not statistically different. If the DWPF lab were to adopt this digestion strategy, it would be necessary for DWPF engineering to determine the allowable variability in the measurements of the concentration of $\mathrm{Al}$. It should be noted that the Al concentration determined in the DWPF CC digestion before digestion of the filtered solids was approximately 2.5\% lower than the combined $\mathrm{Al}$ result after digestion of the undissolved solids.

The ICP-ES results of analysis of the ARG standards that were digested in tandem along with the boehmite spiked SB4 simulant are shown in Table 3.6. Statistically significant differences in the means compared to the ARG reference values werenoted for B, Mg, and Ni. Several elements were found to be in the undissolved solids in the DWPF CC method digestion solutions which were recovered by filtration and dissolved by the subsequent PF. The elements were Al, Ca, Fe, Mg, Mn and Ni. The elements in which there was a statistical difference between digestion results in the first set of ARG samples digested along with the SB4 simulant containing only gibbsite were $\mathrm{Al}, \mathrm{Ca}, \mathrm{Cr}$ and $\mathrm{Mn}$. It was somewhat surprising to identify so many elements from species that either did not dissolve or precipitated from the DWPF CC digestions performed on the ARG standards. In many cases, though, it was such a small amount of material that did not dissolve that it had no impact on the final results and statistical analysis. In the current case, only 2 of the 6 elements that had species which may not have dissolved fully during the CC digestion actually ended up having statistically different means when compared to the PF data. Calcium is a contaminant in the fusion reagents and so the higher average concentration measured by ICP-ES in the PF samples was expected. The PF digestion is performed in a $\mathrm{Zr}$ crucible, a source of $\mathrm{Zr}$ contamination. The higher potassium concentration in the PF was unexpected and the reason for it is unclear. 
Table 3.6 ICP-ES analysis results from digested (DWPF CC + PF digestion of the undissolved solids in the DWPF CC Method solutions versus PF) ARG samples and statistical comparison of the data to the ARG reference value. Values are presented on a wt \% dried solids basis.

\begin{tabular}{|c|c|c|c|c|c|c|c|}
\hline Element & $\begin{array}{c}\text { Wt \% from } \\
\text { DWPF CC+PF of } \\
\text { Undissolved } \\
\text { Solids * }\end{array}$ & $\% \mathrm{RSD}^{\#}$ & $\begin{array}{l}\text { Wt \% from } \\
\text { PF } \\
\text { Digestion* }\end{array}$ & $\% \mathrm{RSD}^{\#}$ & $\begin{array}{l}\text { Statistically Different } \\
\text { Means (Combined } \\
\text { Digestion Result versus } \\
\text { Reference Value, at a } \\
\text { 5\% Significance Level) }\end{array}$ & $\begin{array}{l}\text { DWPF CC + PF of } \\
\text { Undissolved Solids } \\
\text { Result Ratio to } \\
\text { True Value }\end{array}$ & $\begin{array}{c}\text { PF } \\
\text { Digestion Result } \\
\text { Ratio to True } \\
\text { Value }\end{array}$ \\
\hline $\mathrm{Al}$ & $2.45 \mathrm{E}+00$ & $3.2 \mathrm{E}+00$ & $2.38 \mathrm{E}+00$ & $4.8 \mathrm{E}+00$ & No & 0.98 & 0.95 \\
\hline $\mathrm{B}$ & $2.80 \mathrm{E}+00$ & 9.8E-01 & $2.66 \mathrm{E}+00$ & $6.0 \mathrm{E}+00$ & Yes & 1.04 & 0.99 \\
\hline $\mathrm{Ca}$ & 9.98E-01 & $4.9 \mathrm{E}+00$ & $1.16 \mathrm{E}+00$ & $6.2 \mathrm{E}+00$ & No & 0.98 & 1.14 \\
\hline $\mathrm{Cr}$ & 6.79E-02 & $4.9 \mathrm{E}+00$ & 6.67E-02 & $4.0 \mathrm{E}+00$ & No & 1.06 & 1.04 \\
\hline $\mathrm{Cu}$ & $<5.00 \mathrm{E}-02$ & NA & $<1.78 \mathrm{E}-02$ & NA & NA & NA & NA \\
\hline $\mathrm{Fe}$ & $9.88 \mathrm{E}+00$ & 7.0E-01 & $9.67 \mathrm{E}+00$ & $4.7 \mathrm{E}+00$ & No & 1.01 & 0.99 \\
\hline $\mathrm{Li}$ & $2.13 E+00$ & $8.6 \mathrm{E}+00$ & $1.47 \mathrm{E}+00$ & $4.7 \mathrm{E}+00$ & No & 0.94 & 0.99 \\
\hline $\mathrm{K}$ & $1.50 \mathrm{E}+00$ & 8.1E-01 & $2.52 \mathrm{E}+00$ & $9.0 \mathrm{E}+00$ & No & 1.01 & 1.12 \\
\hline $\mathrm{Mg}$ & 4.93E-01 & 7.7E-01 & 4.79E-01 & $5.1 \mathrm{E}+00$ & Yes & 0.95 & 0.92 \\
\hline $\mathrm{Mn}$ & $1.45 \mathrm{E}+00$ & 3.8E-01 & $1.43 \mathrm{E}+00$ & $5.3 \mathrm{E}+00$ & No & 1.00 & 0.98 \\
\hline $\mathrm{Na}$ & $8.21 \mathrm{E}+00$ & $5.9 \mathrm{E}-01$ & NA & NA & NA & 0.96 & NA \\
\hline $\mathrm{Ni}$ & 8.60E-01 & $8.4 \mathrm{E}-01$ & 7.98E-01 & $4.8 \mathrm{E}+00$ & Yes & 1.04 & 0.96 \\
\hline $\mathrm{Si}$ & $2.11 \mathrm{E}+01$ & $1.8 \mathrm{E}+00$ & $2.19 \mathrm{E}+01$ & $5.0 \mathrm{E}+00$ & No & 0.94 & 0.98 \\
\hline $\mathrm{Ti}$ & 7.01E-01 & $1.1 \mathrm{E}+00$ & 6.89E-01 & $4.6 \mathrm{E}+00$ & No & 1.02 & 1.00 \\
\hline $\mathrm{U}^{\wedge}$ & NA & NA & NA & NA & NA & NA & NA \\
\hline $\mathrm{Zr}$ & 1.05E-01 & $3.0 \mathrm{E}+00$ & NA & NA & NA & 1.09 & NA \\
\hline
\end{tabular}

*Three samples were digested by each method and analyzed by ICP-ES. ${ }^{\#} \% \mathrm{RSD}=$ percent relative standard deviation.

$\wedge$ Uranium is not present in the simulant sludge.

The ICP-ES results from analysis of the multi-element standards submitted with the boehmite spiked samples are summarized in Table 3.7. One purified boehmite sample was dissolved using the PF digestion along with this sample batch. The recovery of $\mathrm{Al}$ on an elemental basis based on ICPES data was $97.4 \%$.

Table 3.7 Multi-element ICP-ES standard results. Standards were analyzed as part of the sample batch that included he samples in Table 3.4 and Table 3.6.

\begin{tabular}{|c|c|c|c|c|c|c|c|c|c|}
\hline & & \multicolumn{3}{|c|}{$\begin{array}{c}\text { DWPF CC + PF Sample Batch } \\
\text { Analysis }\end{array}$} & \multicolumn{3}{c|}{ PF Sample Batch Analysis } \\
\hline Element & $\begin{array}{c}\text { Reference } \\
\text { Value }\end{array}$ & $\begin{array}{c}\text { Result } \\
(\mathrm{mg} / \mathrm{L}) \\
\text { Run 1* }\end{array}$ & Delta & $\begin{array}{c}\text { Result } \\
(\mathrm{mg} / \mathrm{L}) \\
\text { Run 2^}\end{array}$ & Delta & $\begin{array}{c}\text { Result } \\
(\mathrm{mg} / \mathrm{L}) \\
\text { Run 1* }\end{array}$ & Delta & $\begin{array}{c}\text { Result } \\
(\mathrm{mg} / \mathrm{L}) \\
\text { Run 1^ }\end{array}$ & Delta \\
\hline $\mathrm{Al}$ & 4 & 3.9 & -2.3 & 3.7 & -7.3 & 3.7 & -6.8 & 4.0 & 0.5 \\
\hline $\mathrm{B}$ & 20 & 19.9 & -0.5 & 19.5 & -2.5 & 19.9 & -0.5 & 19.5 & -2.5 \\
\hline $\mathrm{Fe}$ & 4 & 4.0 & 0.2 & 4.0 & -1.0 & 4.03 & 0.8 & 4.0 & 0.2 \\
\hline $\mathrm{Li}$ & 10 & 10.2 & 2.0 & 10.4 & 4.0 & 10.4 & 4.0 & 10.3 & 3.0 \\
\hline $\mathrm{K}$ & 10 & 9.4 & -6.2 & 9.4 & -5.6 & 10.8 & 8.0 & 12.6 & 26.0 \\
\hline $\mathrm{Si}$ & 50 & 49.9 & -0.2 & 48.4 & -3.2 & 49.4 & -1.2 & 49.3 & -1.4 \\
\hline $\mathrm{Na}$ & 81 & 81.2 & 0.2 & 80.8 & -0.2 & NA & NA & NA & NA \\
\hline
\end{tabular}

*Multi-ement standard analyzed within the first few samples of the batch. ^^Muli-element standard analyzed at the end of the sample batch.

The ICP-ES results from analysis of duplicate digestions of feldspar and triplicate digestions of purified boehmite are shown in Table 3.8 and Table 3.9. The iron oxide $\mathrm{Fe}_{2} \mathrm{O}_{3}$ result in Table 3.8 is high. The 
reason is unclear but Fe is present at such a low level in the feldspar that a minor amount of contaminant would result in a large difference versus the $\mathrm{Fe}_{2} \mathrm{O}_{3}$ reference value. A low sodium oxide $\left(\mathrm{Na}_{2} \mathrm{O}\right)$ value was obtained and is noted in Table 3.8 for the $2^{\text {nd }}$ sample. Again, the reason the measured sodium value is low is unclear, but most likely it is an ICP problem rather than a problem with the digestion because the other elements are close to their given reference values. In both cases, the measured $\mathrm{Al}$ values agree reasonably well compared to the standard reference value for this element.

Table 3.8 ICP-ES results from analysis of digested feldspar. Feldspar was digested in duplicate and in tandem with the samples listed in Table 3.6, Table 3.7 and Table 3.9.

\begin{tabular}{|c|c|c|c|c|c|}
\hline \multicolumn{7}{|c|}{ DWPF CC + PF of Feldspar } \\
\hline Element & $\begin{array}{c}\text { Wt\% Oxide } \\
\text { Reference } \\
\text { Value }\end{array}$ & $\begin{array}{c}\text { Sample 1 } \\
\text { Wt\% }\end{array}$ & Delta & $\begin{array}{c}\text { Sample 2 } \\
\text { Wt\% }\end{array}$ & Delta \\
\hline $\mathrm{Al}_{2} \mathrm{O}_{3}$ & 20.5 & 19.8 & -3.3 & 19.9 & -2.8 \\
\hline $\mathrm{BaO}$ & 0.26 & 0.26 & -1.7 & 0.26 & 1.8 \\
\hline $\mathrm{CaO}$ & 2.14 & 2.15 & 0.5 & 2.24 & 4.8 \\
\hline $\mathrm{Fe}_{2} \mathrm{O}_{3}$ & 0.06 & 0.09 & 44.1 & 0.26 & 326.2 \\
\hline $\mathrm{Na}_{2} \mathrm{O}$ & 6.2 & 5.73 & -7.6 & 3.12 & -49.6 \\
\hline $\mathrm{SiO}_{2}$ & 65.2 & 69.4 & 6.4 & 68.3 & 4.7 \\
\hline
\end{tabular}

Purified boehmite was digested in triplicate as quality control samples. The results are listed in Table 3.9. In all cases the measured boehmite concentration is low. This can be attributed to the difficulty encountered trying to transfer the boehmite out of the bottle into a filter to collect the undissolved solids. The boehmite powder kept sticking to the sides of the plastic bottle and could not be easily rinsed out.

Table 3.9 ICP-ES results from analysis of digested purified boehmite. Purified boehmite was digested in triplicate and in tandem with the samples listed in Table 3.6, Table 3.7 and Table 3.8.

\begin{tabular}{|c|c|c|c|c|c|c|c|}
\hline Element & $\begin{array}{c}\text { Wt\% } \\
\text { Elemental } \\
\text { Reference } \\
\text { Value }\end{array}$ & $\begin{array}{c}\text { Sample 1 } \\
\mathrm{Wt} \%\end{array}$ & Delta & $\begin{array}{c}\text { Sample 2 } \\
\mathrm{Wt} \%\end{array}$ & Delta & $\begin{array}{c}\text { Sample 3 } \\
\mathrm{Wt} \%\end{array}$ & Delta \\
\hline $\mathrm{Al}$ & 44.98 & 31.5 & -30.0 & 37.6 & -16.3 & 34.8 & -22.7 \\
\hline
\end{tabular}




\subsection{CONCLUSIONS}

The CC + PF digestion of SB4 simulant sludge has shown this method can be used as a possible alternative to the DWPF CC method now being used for process control samples. The experimental results from digestion of SB4 simulant spiked with boehmite indicate the following:

- The measured and combined Al concentration from the CC + PF digestion of SB4 simulant was close to the PF only method indicating that this method will digest all aluminum hydroxide species present. The additional steps necessary to perform the combined digestion method is not expected to significantly increase the burden of the cell technician as PF digestions are already currently performed at DWPF.

- $\quad$ The CC + PF method will result in decreased turnaround times for the DWPF Lab versus the PF only digestion method because only the insoluble solids from the CC digestion will undergo fusion. This will result in a time savings as only milligrams of material will be dried and digested instead of multi-gram quantities of sludge slurry.

- Compounds that tend to precipitate from the DWPF CC digestion solutions (mixed metal fluoride salts) will be digested and measured resulting in a better determination of the $\mathrm{Al}$ concentration in process samples over the current digestion method. 
WSRC-STI-2007-00515

Revision 0

This page intentionally left blank 


\subsection{RECOMMENDATIONS}

The following recommendations are based upon ICP-ES results and statistical analysis of those results from experimental digestion tests conducted with SB4 simulant sludge slurry. It is recommended that the DWPF:

- Pursue a side-by-side development and comparison of the combined digestion method (DWPF CC plus PF of undissolved solids) in the SRNL shielded cells and at the DWPF Lab using radioactive sludge.

- Perform periodic analysis (X-ray diffraction) of solids that may be in the DWPF CC analytical process digestion samples out at DWPF to help further refine the digestion method. 
WSRC-STI-2007-00515

Revision 0

This page intentionally left blank 


\subsection{REFERENCES}

1. C.J. Coleman, F.M. Pennebaker, B.H. Burch and D.R. Click. "Evaluation of the DWPF Cold Chem Dissolution Method with DWPF Sludge Batch 3 Simulant”, WSRC-TR-02-00496, Revision 0. See also D.R. Click. "Evaluation of the DWPF Cold Chem Dissolution Method with Tank 7 and Tank 51 Radioactive Sludges”, WSRC-TR-2003-00580.

2. J.M. Pareizs, et al., "As-Received Sludge Batch 4 (Tank 51) Sample Characterization Results”, SRNL-PSE-2006-00093, May 11, 2006 and Click, D.R. et al., "Sludge Batch Four (4) Defense Waste Processing Facility (DWPF) Process Analytical Method Verification”, SRNL-STI-2006-00025, June 15, 2006.

3. X. Gong, et al., "Gibbsite to Boehmite Transformation in Strongly Caustic and Nitrate Environments”, Ind. Eng. Chem. Res., 42, 2163 (2003)

4. C.J. Coleman. "Alkali Fusion Dissolutions of Sludge and Glass for Elemental and Anion Analysis", ADS Procedure ADS-2502, November, 2002.

5. A.R. Jurgensen, et al., "Boehmite and Gibbsite Synthesis”, SRNL-ADS-2006-00511, October 22, 2006.

6. JMP Statistical Discovery Software v 6.02; SAS Institute Inc., Cary, NC, 2005. 
WSRC-STI-2007-00515

Revision 0

This page intentionally left blank 
WSRC-STI-2007-00515

Revision 0

\subsection{ACKNOWLEDGEMENTS}

The authors would like to acknowledge Art Jurgensen for the supply of boehmite, June Hart and Mark Jones for ICP-ES data, and the PS\&E section. 
Distribution

M.J. Barnes, 773-A

N.E. Bibler, 773-A

L.M. Chandler, 773-A

C.J. Coleman, 773-A

R.E. Edwards, 773-A

T.B. Edwards, 999-W

C.C. Herman, 999-W

R. McNew, 704-27S

R.N. Mahannah, 704-28S

L. Connelly, 704-28S

J.E. Occhipinti, 704-S

J.A. Ray, 704-S

J. Iaukea, 704-28S

B.A. Davis, 704-27S

F.M. Pennebaker, 773-A

R.B. Spencer, 704-28S

C.J. Bannochie, 773-42A

D.R. Best, 786-5A

J.M. Pareizs, 773-A

D.K. Peeler, 999-W

M.E. Stone, 999-W

ADS Files 
WSRC-STI-2007-00515

Revision 0

APPENDIX A

JMP One-Way Analysis Plots of ARG Digested by PF and DWPF CC 
WSRC-STI-2007-00515

Revision 0

Fit Y by X Group

Oneway Analysis of Al By Digestion Type Sample=ARG-1

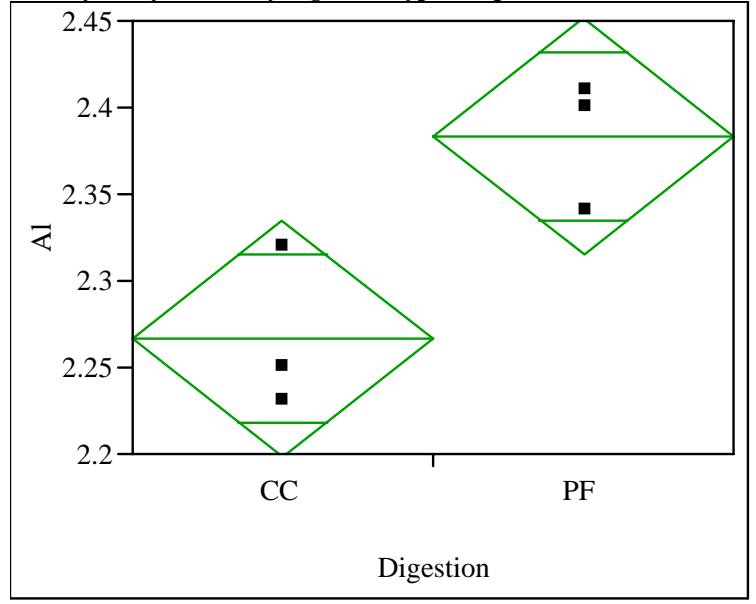

Oneway Anova

Summary of Fit

$\begin{array}{lr}\text { Rsquare } & 0.735736 \\ \text { Adj Rsquare } & 0.66967 \\ \text { Root Mean Square Error } & 0.042817 \\ \text { Mean of Response } & 2.325 \\ \text { Observations (or Sum Wgts) } & 6 \\ & \\ \text { t Test } & \\ \text { PF-CC }\end{array}$

Assuming equal variances

Difference $\quad 0.116667$ t Ratio $\quad 3.337119$

Std Err Dif 0.034960 DF

Upper CL Dif 0.213732 Prob $>|t| \quad 0.0289$

Lower CL Dif 0.019601 Prob $>t \quad 0.0145$

Confidence $\quad 0.95$ Prob $<\mathrm{t} \quad 0.9855$

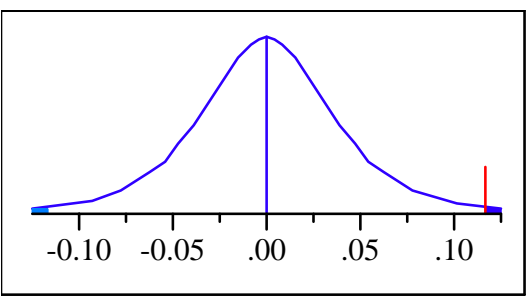

Analysis of Variance

Source DF Sum of Squares Mean Square F Ratio Prob $>$ F

$\begin{array}{lllllll}\text { Digestion } & 1 & 0.02041667 & 0.020417 & 11.1364 & 0.0289\end{array}$

$\begin{array}{llll}\text { Error } & 4 & 0.00733333 & 0.001833\end{array}$

C. Total $5 \quad 0.02775000$

Means for Oneway Anova

Level Number Mean Std Error Lower 95\% Upper 95\%

$\begin{array}{llllll}\text { CC } & 3 & 2.26667 & 0.02472 & 2.1980 & 2.3353\end{array}$

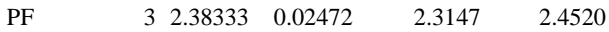

Std Error uses a pooled estimate of error variance
Oneway Analysis of B By Digestion Type Sample=ARG-1

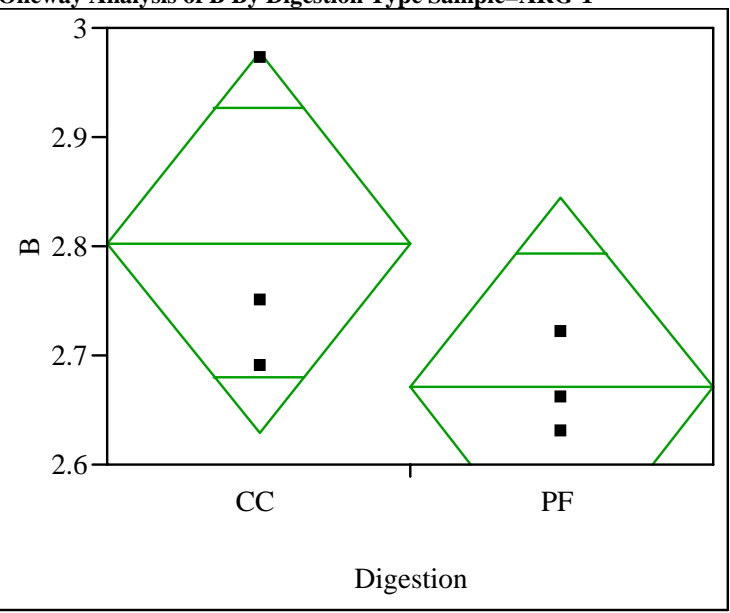

Oneway Anova

Summary of Fit

$\begin{array}{lr}\text { Rsquare } & 0.358744 \\ \text { Adj Rsquare } & 0.19843 \\ \text { Root Mean Square Error } & 0.109163 \\ \text { Mean of Response } & 2.736667 \\ \text { Observations (or Sum Wgts) } & 6\end{array}$

t Test

PF-CC

Assuming equal variances

$\begin{array}{lrlr}\text { Difference } & -0.13333 \text { t Ratio } & -1.49592 \\ \text { Std Err Dif } & 0.08913 \text { DF } & 4 \\ \text { Upper CL Dif } & 0.11414 \text { Prob }>|t| & 0.2090 \\ \text { Lower CL Dif } & -0.38080 & \text { Prob }>t & 0.8955 \\ \text { Confidence } & 0.95 \text { Prob }<\mathrm{t} & 0.1045\end{array}$

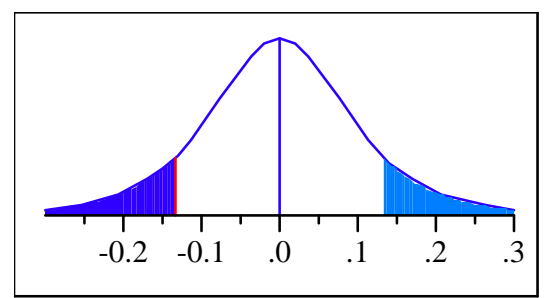

Analysis of Variance

Source DF Sum of Squares Mean Square F Ratio Prob $>$ F

$\begin{array}{llllll}\text { Digestion } & 1 & 0.02666667 & 0.026667 & 2.2378 & 0.2090\end{array}$

$\begin{array}{llll}\text { Error } & 4 & 0.04766667 & 0.011917\end{array}$

C. Total 50.0743333

Means for Oneway Anova

Level Number Mean Std Error Lower 95\% Upper 95\%

$\begin{array}{llllll}\text { CC } & 3 & 2.80333 & 0.06303 & 2.6283 & 2.9783\end{array}$

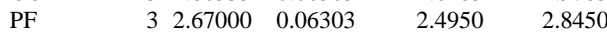

Std Error uses a pooled estimate of error variance 
WSRC-STI-2007-00515

Revision 0

Oneway Analysis of Ba By Digestion Type Sample=ARG-1

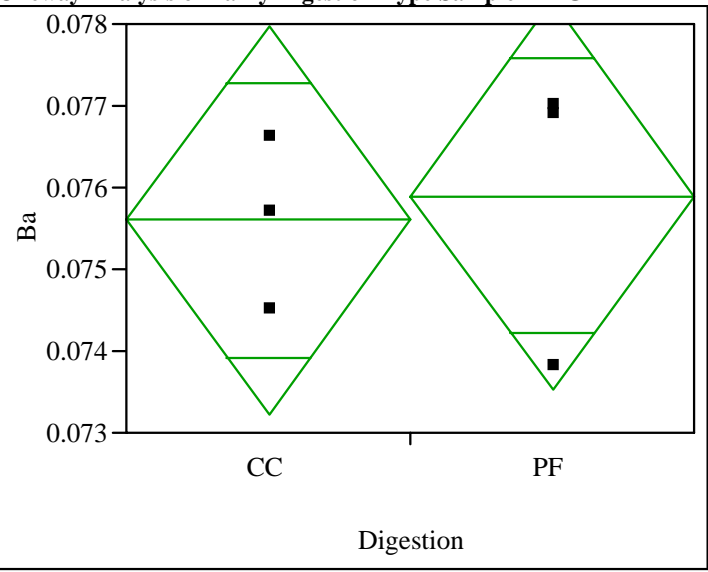

Oneway Anova

Summary of Fit

Rsquare

Adj Rsquare

Root Mean Square Error

0.015042

$-0.2312$

Mean of Response

Observations (or Sum Wgts) 6

t Test

PF-CC

Assuming equal variances

Difference $\quad 0.00030$ t Ratio 0.247156

Std Err Dif $\quad 0.00121$ DF 4

Upper CL Dif 0.00367 Prob $>|t| \quad 0.8170$

Lower CL Dif -0.00307 Prob $>\mathrm{t} \quad 0.4085$

Confidence $\quad 0.95$ Prob $<\mathrm{t} \quad 0.5915$

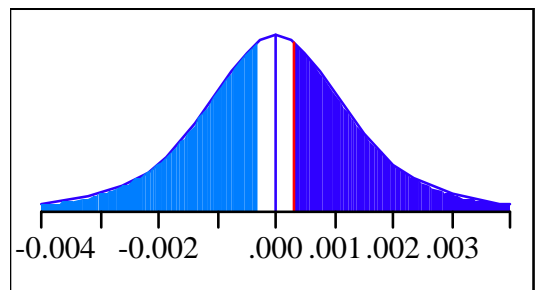

Analysis of Variance

Source DF Sum of Squares Mean Square F Ratio Prob $>$ F

Digestion $1 \quad 1.35 \mathrm{e}-7 \quad 1.35 \mathrm{e}-7 \quad 0.0611 \quad 0.8170$

Error $\quad 4 \quad 0.00000884 \quad 2.21 \mathrm{e}-6$

C. Total $5 \quad 8.975 \mathrm{e}-6$

Means for Oneway Anova

Level Number Mean Std Error Lower 95\% Upper 95\%

$\begin{array}{lllllr}\text { CC } & 3 & 0.075600 & 0.00086 & 0.07322 & 0.07798\end{array}$

$\begin{array}{llllll}\mathrm{PF} & 3 & 0.075900 & 0.00086 & 0.07352 & 0.07828\end{array}$

Std Error uses a pooled estimate of error variance
Oneway Analysis of Ca By Digestion Type Sample=ARG-1

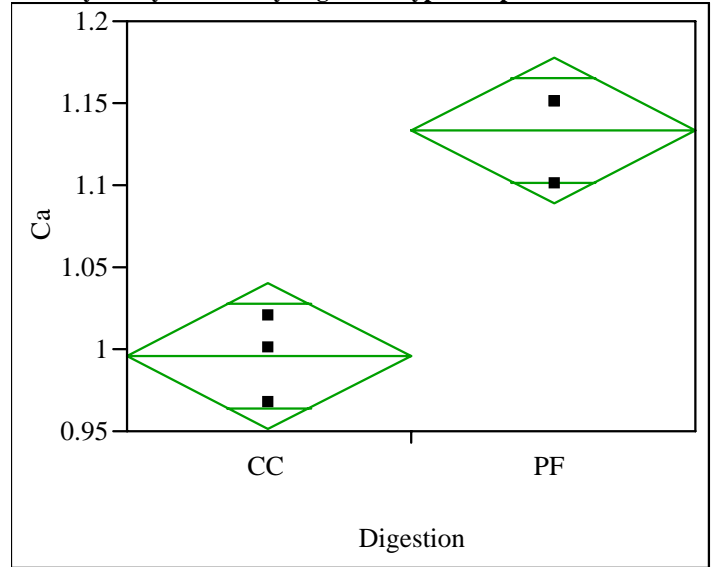

Oneway Anova

Summary of Fit

$\begin{array}{lr}\text { Rsquare } & 0.901694 \\ \text { Adj Rsquare } & 0.877118 \\ \text { Root Mean Square Error } & 0.027836 \\ \text { Mean of Response } & 1.0645 \\ \text { Observations (or Sum Wgts) } & 6 \\ & \\ \text { t Test } & \\ \text { PF-CC }\end{array}$

Assuming equal variances

$\begin{array}{lrlr}\text { Difference } & 0.137667 & \text { t Ratio } & 6.057177 \\ \text { Std Err Dif } & 0.022728 \text { DF } & 4 \\ \text { Upper CL Dif } & 0.200769 \text { Prob }>|t| & 0.0037 \\ \text { Lower CL Dif } & 0.074564 \text { Prob }>\text { t } & 0.0019 \\ \text { Confidence } & 0.95 \text { Prob }<\mathrm{t} & 0.9981\end{array}$

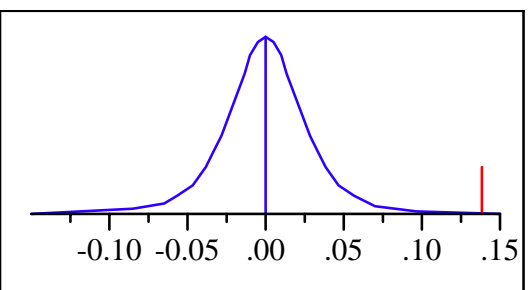

Analysis of Variance

Source DF Sum of Squares Mean Square F Ratio Prob $>$ F

$\begin{array}{llllll}\text { Digestion } & 1 & 0.02842817 & 0.028428 & 36.6894 & 0.0037\end{array}$

$\begin{array}{llll}\text { Error } & 4 & 0.00309933 & 0.000775\end{array}$

C. Total $5 \quad 0.03152750$

Means for Oneway Anova

Level Number Mean Std Error Lower 95\% Upper 95\%

$\begin{array}{llllll}\text { CC } & 3 & 0.99567 & 0.01607 & 0.9510 & 1.0403\end{array}$

$\begin{array}{llllll}\mathrm{PF} & 3 & 1.13333 & 0.01607 & 1.0887 & 1.1780\end{array}$

Std Error uses a pooled estimate of error variance 
WSRC-STI-2007-00515

Revision 0

Oneway Analysis of Cr By Digestion Type Sample=ARG-1

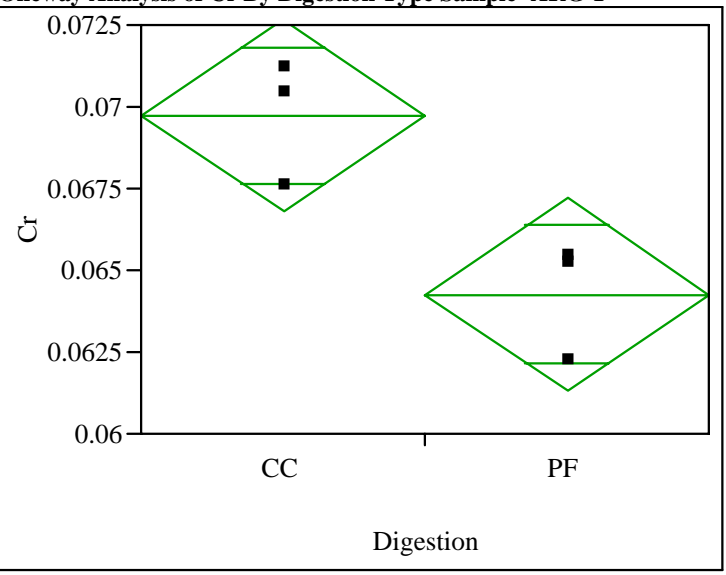

Oneway Anova

Summary of Fit

Rsquare

Adj Rsquare

0.76758

0.709475

Root Mean Square Error $\quad 0.001842$

Mean of Response

0.067

Observations (or Sum Wgts)

6

t Test

PF-CC

Assuming equal variances

Difference $\quad-0.00547$ t Ratio $\quad-3.63459$

Std Err Dif $\quad 0.00150$ DF 4

Upper CL Dif -0.00129 Prob $>|t| \quad 0.0221$

Lower CL Dif -0.00964 Prob $>$ t 0.9890

Confidence $\quad 0.95$ Prob $<\mathrm{t} \quad 0.0110$

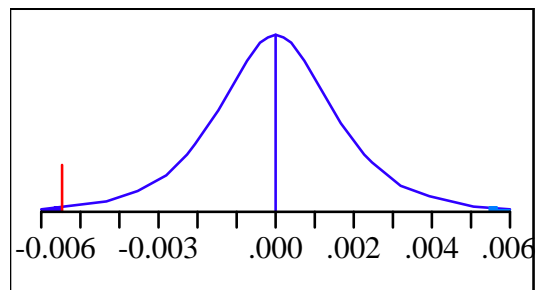

Analysis of Variance

Source DF Sum of Squares Mean Square F Ratio Prob $>$ F

$\begin{array}{llllll}\text { Digestion } & 1 & 0.00004483 & 0.000045 & 13.2102 & 0.0221\end{array}$

$\begin{array}{llll}\text { Error } & 4 & 0.00001357 & 3.393 \mathrm{e}-6\end{array}$

C. Total $5 \quad 0.00005840$

Means for Oneway Anova

Level Number Mean Std Error Lower 95\% Upper 95\%

$\begin{array}{llllll}\text { CC } & 3 & 0.069733 & 0.00106 & 0.06678 & 0.07269\end{array}$

$\begin{array}{llllll}\mathrm{PF} & 3 & 0.064267 & 0.00106 & 0.06131 & 0.06722\end{array}$

Std Error uses a pooled estimate of error variance
Oneway Analysis of Cu By Digestion Type Sample=ARG-1

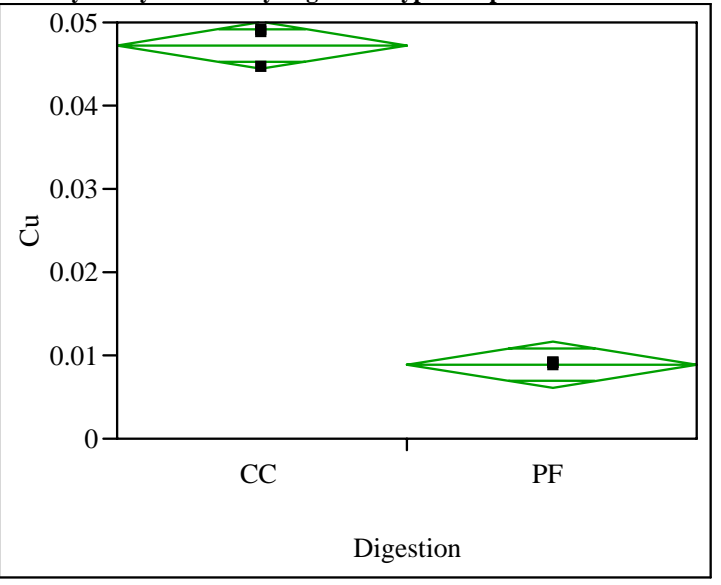

Oneway Anova

Summary of Fit

Rsquare

Adj Rsquare

0.994667

Root Mean Squa

0.993334

0.028055

t Test

PF-CC

Assuming equal variances

$\begin{array}{lrlr}\text { Difference } & -0.03849 & \mathrm{t} \text { Ratio } & -27.3139 \\ \text { Std Err Dif } & 0.00141 & \text { DF } & 4 \\ \text { Upper CL Dif } & -0.03458 \text { Prob }>|t| & <.0001 \\ \text { Lower CL Dif } & -0.04240 & \text { Prob }>t & 1.0000 \\ \text { Confidence } & 0.95 & \text { Prob }<\mathrm{t} & <.0001\end{array}$

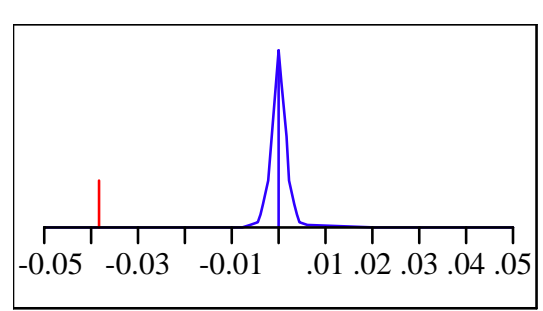

Analysis of Variance

Source DF Sum of Squares Mean Square F Ratio Prob $>$ F

$\begin{array}{llllll}\text { Digestion } & 1 & 0.00222222 & 0.002222 & 746.0494 & <.0001\end{array}$

$\begin{array}{llll}\text { Error } & 4 & 0.00001191 & 2.979 \mathrm{e}-6\end{array}$

C. Total $5 \quad 0.00223413$

Means for Oneway Anova

Level Number Mean Std Error Lower 95\% Upper 95\%

$\begin{array}{llllll}\text { CC } & 3 & 0.047300 & 0.00100 & 0.04453 & 0.05007\end{array}$

$\begin{array}{llllll}\mathrm{PF} & 3 & 0.008810 & 0.00100 & 0.00604 & 0.01158\end{array}$

Std Error uses a pooled estimate of error variance 
WSRC-STI-2007-00515

Revision 0

Oneway Analysis of Fe By Digestion Type Sample=ARG-1

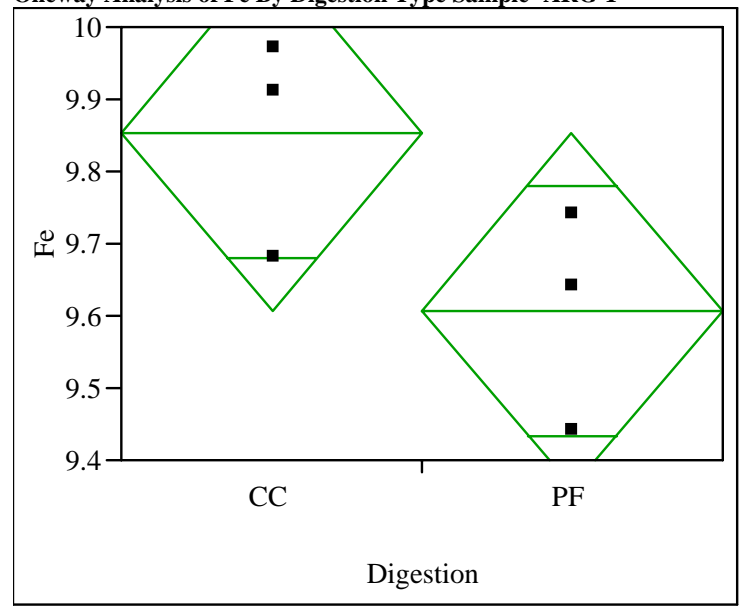

Oneway Anova

Summary of Fit

Rsquare

Adj Rsquare

0.493867

0.367334

Root Mean Square Error $\quad 0.152916$

Mean of Response

Observations (or Sum Wgts)

9.73

t Test

PF-CC

Assuming equal variance

Difference $\quad-0.24667$ t Ratio $\quad-1.97562$

Std Err Dif $\quad 0.12486$ DF 4

Upper CL Dif 0.09999 Prob $>|\mathrm{t}| \quad 0.1194$

Lower CL Dif -0.59332 Prob $>$ t 0.9403

$\begin{array}{lll}\text { Confidence } & 0.95 \text { Prob }<\mathrm{t} \quad 0.0597\end{array}$

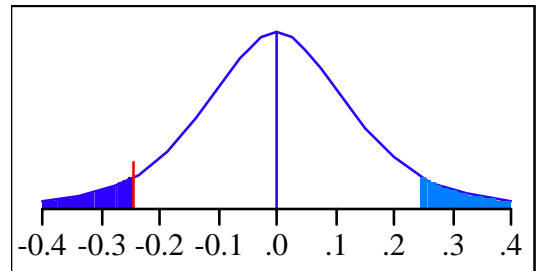

Analysis of Variance

Source DF Sum of Squares Mean Square F Ratio Prob $>$ F

$\begin{array}{lrrrrr}\text { Digestion } & 1 & 0.09126667 & 0.091267 & 3.9031 & 0.1194\end{array}$

$\begin{array}{llll}\text { Error } & 4 & 0.09353333 & 0.023383\end{array}$

C. Total $5 \quad 0.18480000$

Means for Oneway Anova

Level Number Mean Std Error Lower 95\% Upper 95\%

$\begin{array}{llllll}\text { CC } & 3 & 9.85333 & 0.08829 & 9.6082 & 10.098\end{array}$

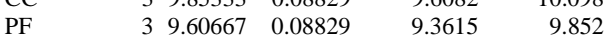

Std Error uses a pooled estimate of error variance
Oneway Analysis of K By Digestion Type Sample=ARG-1

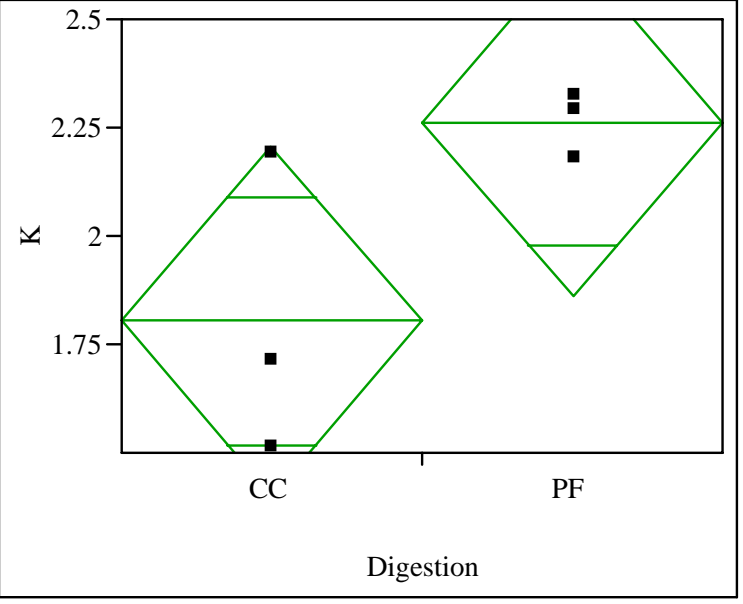

Oneway Anova

Summary of Fit

Rsquare

Adj Rsquare $\quad 0.442973$

Root Mean Square Error $\quad 0.252554$

Mean of Response 2.03333

Observations (or Sum Wgts)

t Test

PF-CC

Assuming equal variances

Difference $\quad 0.4600$ t Ratio 2.230745

Std Err Dif $\quad 0.2062$ DF 4

Upper CL Dif 1.0325 Prob > $|\mathrm{t}| \quad 0.0895$

Lower CL Dif -0.1125 Prob $>\mathrm{t} \quad 0.0448$

$\begin{array}{lll}\text { Confidence } & 0.95 \text { Prob }<\mathrm{t} \quad 0.9552\end{array}$

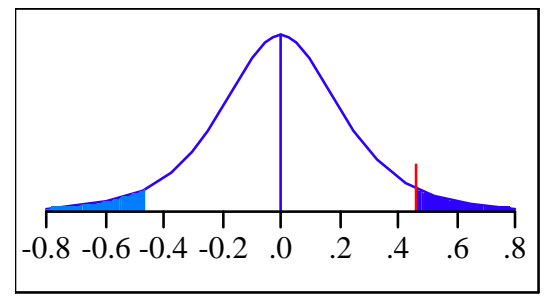

Analysis of Variance

Source DF Sum of Squares Mean Square F Ratio Prob $>$ F

$\begin{array}{lrrrrr}\text { Digestion } & 1 & 0.31740000 & 0.317400 & 4.9762 & 0.0895\end{array}$

$\begin{array}{llll}\text { Error } & 4 & 0.25513333 & 0.063783\end{array}$

C. Total $5 \quad 0.57253333$

Means for Oneway Anova

Level Number Mean Std Error Lower 95\% Upper 95\%

$\begin{array}{lllllr}\text { CC } & 3 & 1.80333 & 0.14581 & 1.3985 & 2.2082\end{array}$

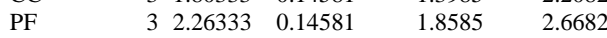

Std Error uses a pooled estimate of error variance 
WSRC-STI-2007-00515

Revision 0

Oneway Analysis of Li By Digestion Type Sample=ARG-1

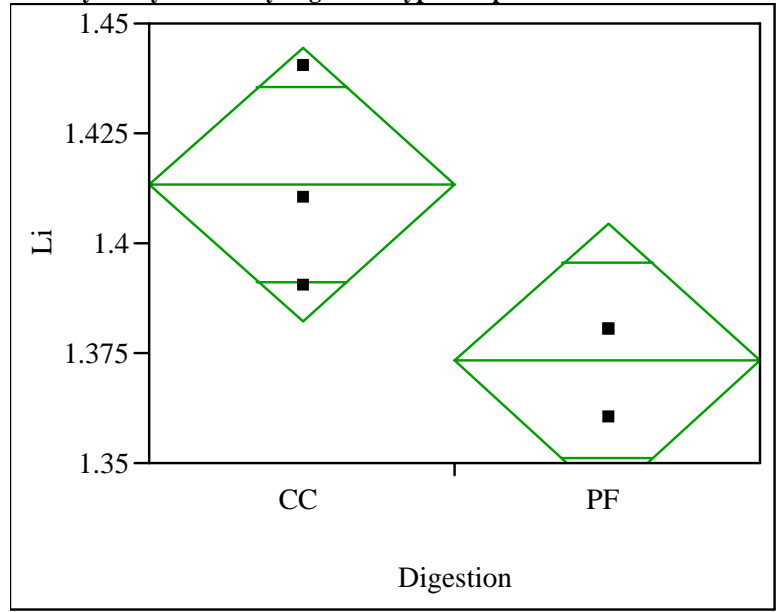

Oneway Anova

Summary of Fit

Rsquare

Adj Rsquare

0.610169

Root Mean Square Error $\quad 0.019579$

Mean of Response 1.39333

Observations (or Sum Wgts)

t Test

PF-CC

Assuming equal variances

Difference $\quad-0.04000$ t Ratio $\quad-2.50217$

Std Err Dif $\quad 0.01599$ DF 4

Upper CL Dif 0.00438 Prob $>|t| \quad 0.0666$

Lower CL Dif -0.08438 Prob $>\mathrm{t} \quad 0.9667$

Confidence $\quad 0.95$ Prob $<\mathrm{t} \quad 0.0333$

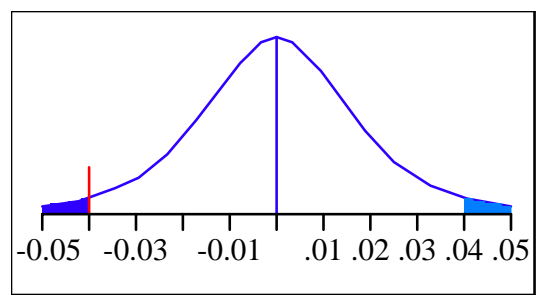

Analysis of Variance

Source DF Sum of Squares Mean Square F Ratio Prob $>$ F

$\begin{array}{llllll}\text { Digestion } & 1 & 0.00240000 & 0.002400 & 6.2609 & 0.0666\end{array}$

$\begin{array}{lll}\text { Error } \quad 4 & 0.00153333\end{array}$

$\begin{array}{lll}\text { C. Total } & 5 & 0.00393333\end{array}$

Means for Oneway Anova

Level Number Mean Std Error Lower 95\% Upper 95\%

$\begin{array}{llllll}\text { CC } & 3 & 1.41333 & 0.01130 & 1.3819 & 1.4447\end{array}$

$\begin{array}{llllll}\text { PF } & 3 & 1.37333 & 0.01130 & 1.3419 & 1.4047\end{array}$

Std Error uses a pooled estimate of error variance
Oneway Analysis of Mg By Digestion Type Sample=ARG-1

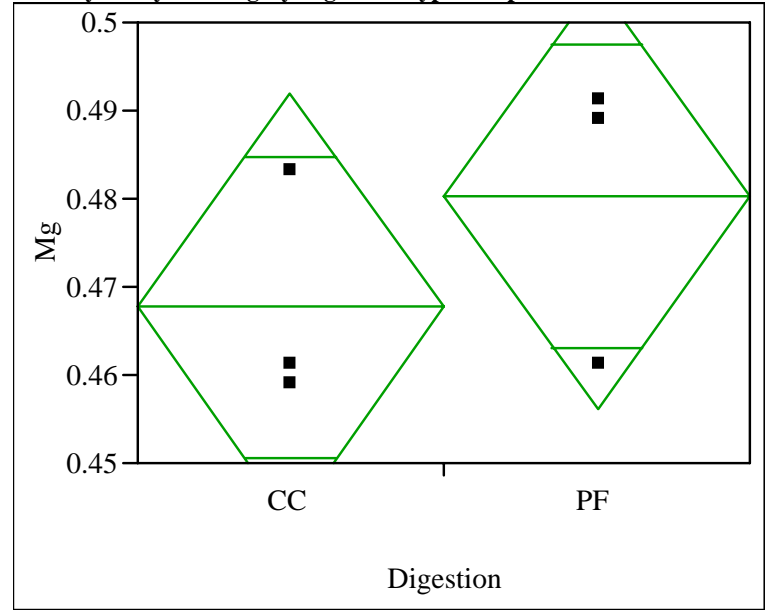

Oneway Anova

Summary of Fit

Rsquare

Adj Rsquare

0.20783

Root Mean Square

0.009787

$\begin{array}{lr}\text { Mean of Response } & 0.474 \\ \text { Observations (or Sum Wgts) } & 6\end{array}$

t Test

PF-CC

Assuming equal variances

$\begin{array}{lrlr}\text { Difference } & 0.01267 & \text { t Ratio } & 1.024411 \\ \text { Std Err Dif } & 0.01236 & \text { DF } & 4 \\ \text { Upper CL Dif } & 0.04700 & \text { Prob }>|t| & 0.3635 \\ \text { Lower CL Dif } & -0.02166 & \text { Prob }>\text { t } & 0.1818 \\ \text { Confidence } & 0.95 & \text { Prob }<\mathrm{t} & 0.8182\end{array}$

Confidence $\quad 0.95$ Prob $<\mathrm{t} \quad 0.8182$

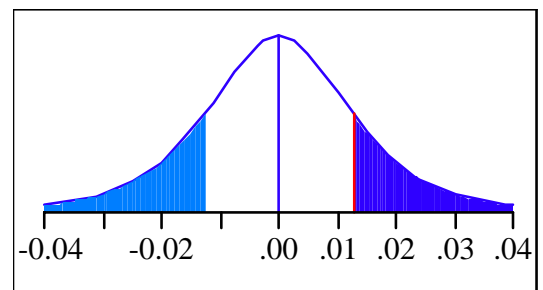

Analysis of Variance

Source DF Sum of Squares Mean Square F Ratio Prob $>$ F

$\begin{array}{llllll}\text { Digestion } & 1 & 0.00024067 & 0.000241 & 1.0494 & 0.3635\end{array}$

$\begin{array}{llll}\text { Error } & 4 & 0.00091733 & 0.000229\end{array}$

C. Total $5 \quad 0.00115800$

Means for Oneway Anova

Level Number Mean Std Error Lower 95\% Upper 95\%

$\begin{array}{llllll}\text { CC } & 3 & 0.467667 & 0.00874 & 0.44339 & 0.49194\end{array}$

$\begin{array}{llllll}\mathrm{PF} & 3 & 0.480333 & 0.00874 & 0.45606 & 0.50461\end{array}$

Std Error uses a pooled estimate of error variance 
WSRC-STI-2007-00515

Revision 0

Oneway Analysis of Mn By Digestion Type Sample=ARG-1

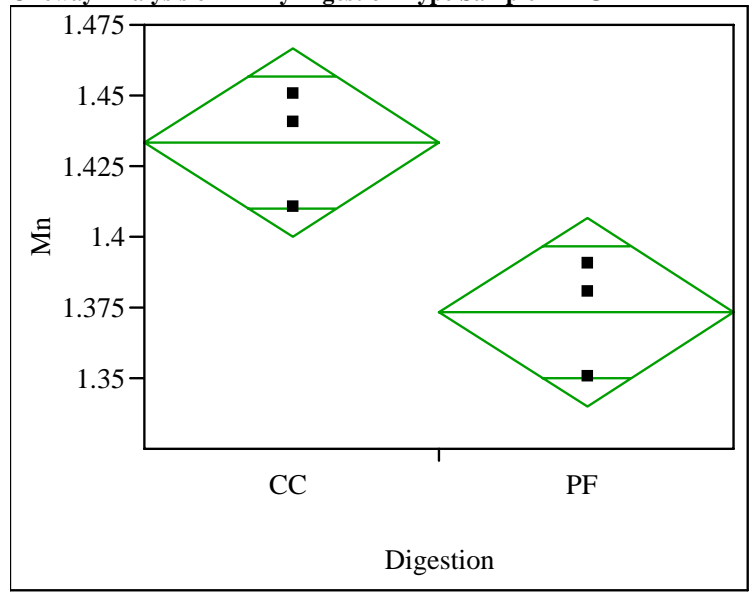

Oneway Anova

Summary of Fit

Rsquare

Adj Rsquare

Root Mean Square Error

Mean of Response

0.757009

0.696262

0.020817

1.403333

Observations (or Sum Wgts)

6

t Test

PF-CC

Assuming equal variances

Difference $\quad-0.06000$ t Ratio -3.53009

Std Err Dif $\quad 0.01700$ DF 4

Upper CL Dif -0.01281 Prob $>|t| \quad 0.0242$

Lower CL Dif -0.10719 Prob $>$ t 0.9879

Confidence $\quad 0.95$ Prob $<\mathrm{t} \quad 0.0121$

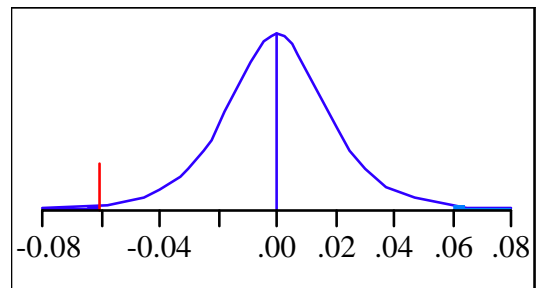

Analysis of Variance

Source DF Sum of Squares Mean Square F Ratio Prob $>$ F

$\begin{array}{lllllll}\text { Digestion } & 1 & 0.00540000 & 0.005400 & 12.4615 & 0.0242\end{array}$

Error $4 \quad 0.00173333$

C. Total $5 \quad 0.00713333$

Means for Oneway Anova

Level Number Mean Std Error Lower 95\% Upper 95\%

$\begin{array}{llrrrr}\mathrm{CC} & 3 & 1.43333 & 0.01202 & 1.4000 & 1.4667\end{array}$

$\begin{array}{llllll}\text { PF } & 3 & 1.37333 & 0.01202 & 1.3400 & 1.4067\end{array}$

Std Error uses a pooled estimate of error variance
Oneway Analysis of Na By Digestion Type Sample=ARG-1

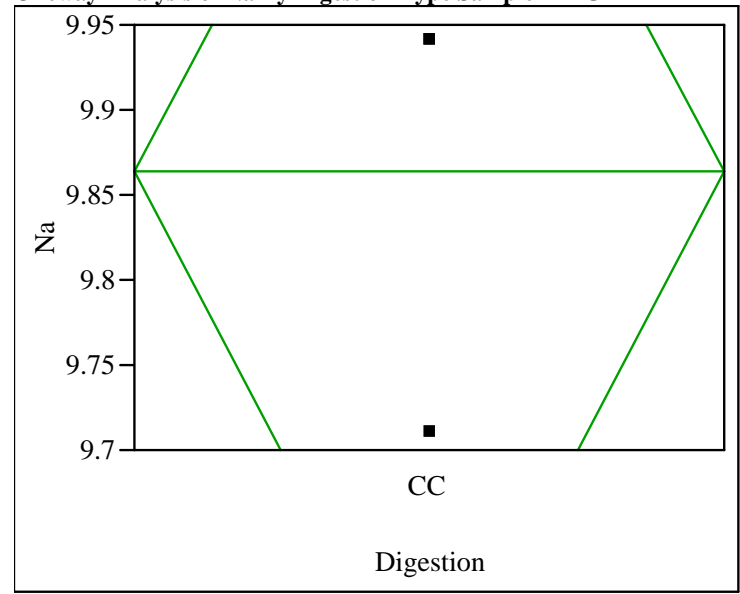

Missing Rows

3

Oneway Anova

Summary of Fit

Rsquare

Adj Rsquare

Root Mean Square Error $\quad 0.132791$

Mean of Response 9.863333

Observations (or Sum Wgts) 3

Analysis of Variance

Source DF Sum of Squares Mean Square F Ratio Prob $>$ F

Digestion $0 \quad 0.00000000$

$\begin{array}{lll}\text { Error } & 2 & 0.03526667\end{array}$

C. Total $2 \quad 0.03526667$ 0.017633

Means for Oneway Anova

Level Number Mean Std Error Lower 95\% Upper 95\%

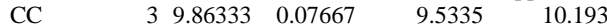

Std Error uses a pooled estimate of error variance 
WSRC-STI-2007-00515

Revision 0

Oneway Analysis of Ni By Digestion Type Sample=ARG-1

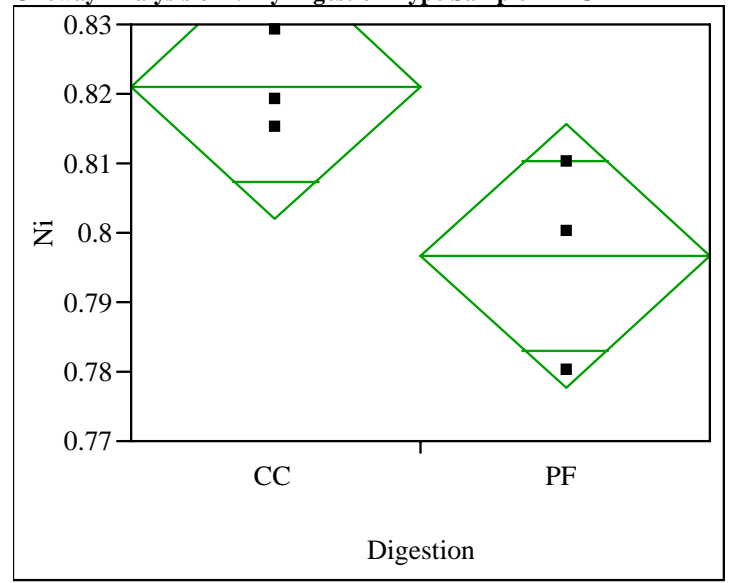

Oneway Anova

Summary of Fit

Rsquare

0.60882

Adj Rsquare

0.511025

Root Mean Square Error $\quad 0.011944$

Mean of Response 0.808833

Observations (or Sum Wgts)

6

t Test

PF-CC

Assuming equal variances

Difference $\quad-0.02433$ t Ratio $\quad-2.49509$

Std Err Dif 0.00975 DF 4

Upper CL Dif 0.00274 Prob $>|t| \quad 0.0671$

Lower CL Dif -0.05141 Prob $>t \quad 0.9664$

$\begin{array}{lr}\text { Confidence } & 0.95 \text { Prob }<\mathrm{t} \quad 0.0336\end{array}$

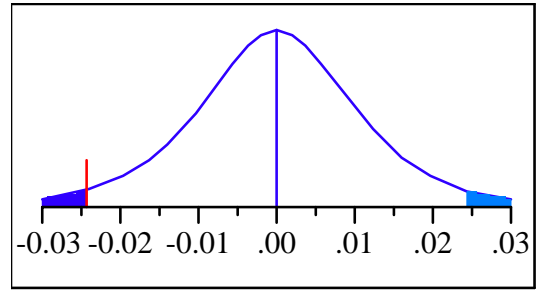

Analysis of Variance

Source DF Sum of Squares Mean Square F Ratio Prob $>$ F

$\begin{array}{lrrrrr}\text { Digestion } & 1 & 0.00088817 & 0.000888 & 6.2255 & 0.0671\end{array}$

$\begin{array}{llll}\text { Error } & 4 & 0.00057067 & 0.000143\end{array}$

C. Total 50.00145883

Means for Oneway Anova

Level Number Mean Std Error Lower 95\% Upper 95\%

$\begin{array}{llllll}\text { CC } & 3 & 0.821000 & 0.00690 & 0.80185 & 0.84015\end{array}$

$\begin{array}{llllll}\mathrm{PF} & 3 & 0.796667 & 0.00690 & 0.77752 & 0.81581\end{array}$

Std Error uses a pooled estimate of error variance
Oneway Analysis of P By Digestion Type Sample=ARG-1

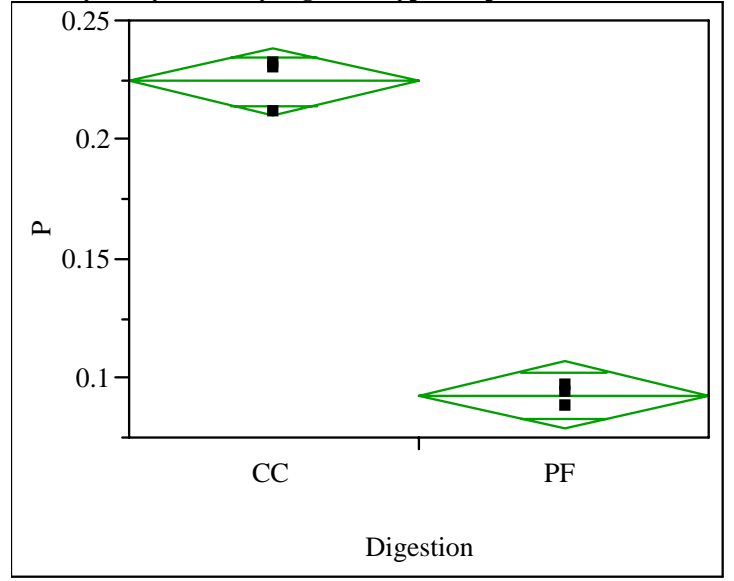

Oneway Anova

Summary of Fit

Rsquare

Adj Rsquare

Root Mean Square Error $\quad 0.008816$

Mean of Response $\quad 0.158483$

Observations (or Sum Wgts)

6

t Test

PF-CC

Assuming equal variances

Difference $\quad-0.13170$ t Ratio $\quad-18.2966$

Std Err Dif $\quad 0.00720$ DF 4

Upper CL Dif -0.11171 Prob $>|t|<.0001$

Lower CL Dif -0.15169 Prob $>$ t 1.0000

Confidence $\quad 0.95$ Prob $<\mathrm{t} \quad<.0001$

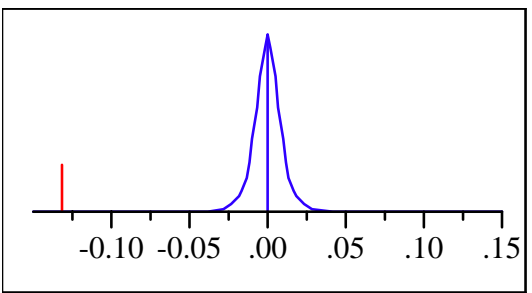

Analysis of Variance

Source DF Sum of Squares Mean Square F Ratio Prob $>$ F

$\begin{array}{llrrrr}\text { Digestion } & 1 & 0.02601734 & 0.026017 & 334.7644 & <.0001\end{array}$

$\begin{array}{llll}\text { Error } & 4 & 0.00031087 & 0.000078\end{array}$

C. Total $5 \quad 0.02632821$

Means for Oneway Anova

Level Number Mean Std Error Lower 95\% Upper 95\%

$\begin{array}{llllll}\text { CC } & 3 & 0.224333 & 0.00509 & 0.21020 & 0.23846\end{array}$

$\begin{array}{llllll}\mathrm{PF} & 3 & 0.092633 & 0.00509 & 0.07850 & 0.10676\end{array}$

Std Error uses a pooled estimate of error variance 
WSRC-STI-2007-00515

Revision 0

Oneway Analysis of Si By Digestion Type Sample=ARG-1

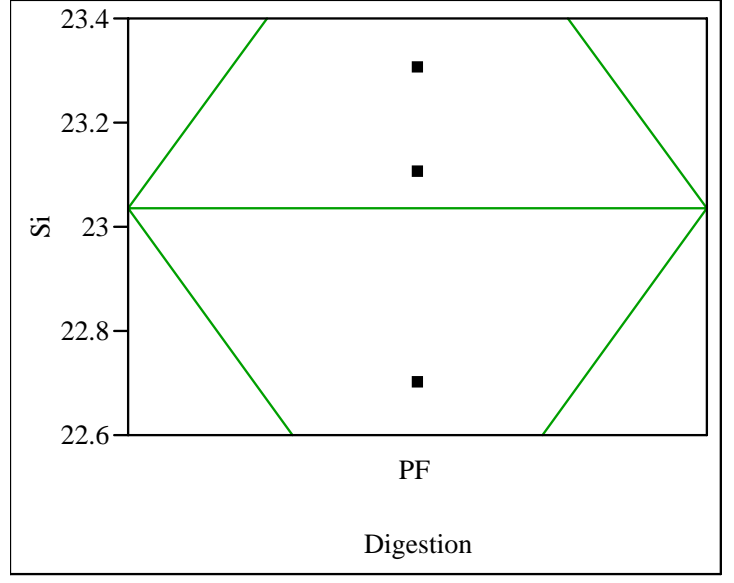

Missing Rows

3

Oneway Anova

Summary of Fit

Rsquare

Adj Rsquare

Root Mean Square Error $\quad 0.305505$

Mean of Response 23.03333

Observations (or Sum Wgts) 3

Analysis of Variance

Source DF Sum of Squares Mean Square F Ratio Prob $>$ F

Digestion $0 \quad 0.00000000$

$\begin{array}{lll}\text { Error } \quad 2 & 0.18666667\end{array}$

C. Total 20.18666667

Means for Oneway Anova

Level Number Mean Std Error Lower 95\% Upper 95\%

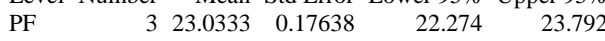

Std Error uses a pooled estimate of error variance
Oneway Analysis of Sr By Digestion Type Sample=ARG-1

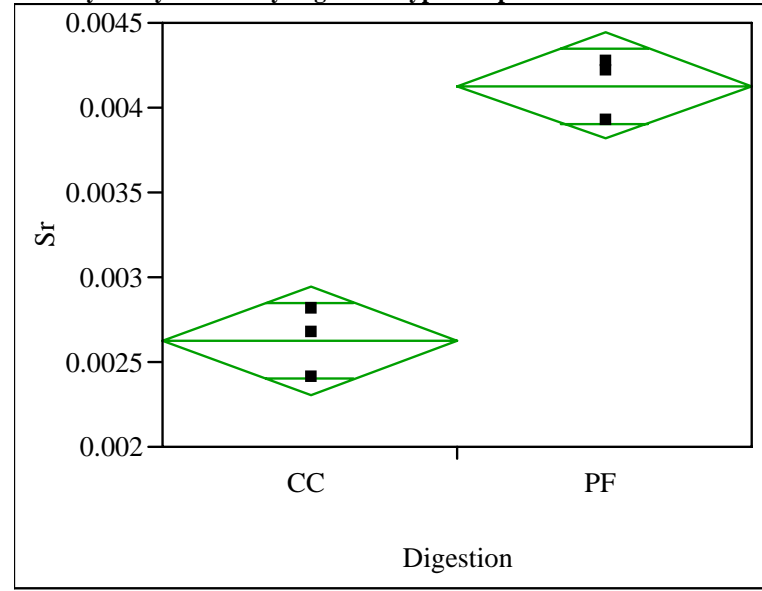

Oneway Anova

Summary of Fit

Rsquare

Adj Rsquare

0.956475

Root Mean Square Error $\quad 0.000196$

Mean of Response

Observations (or Sum Wgts)

6

t Test

PF-CC

Assuming equal variances

Difference $\quad 0.001503$ t Ratio 9.375509

Std Err Dif $\quad 0.000160$ DF 4

Upper CL Dif 0.001949 Prob $>|t| \quad 0.0007$

Lower CL Dif 0.001058 Prob $>t \quad 0.0004$

Confidence $\quad 0.95$ Prob $<\mathrm{t} \quad 0.9996$

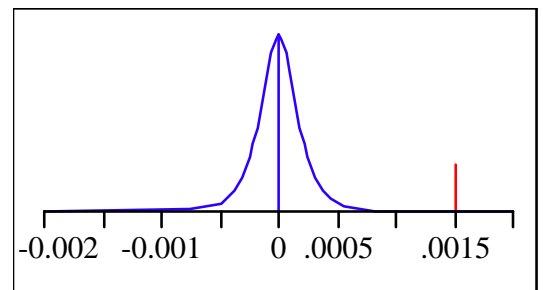

Analysis of Variance

Source DF Sum of Squares Mean Square F Ratio Prob $>$ F

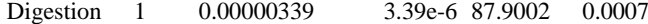

$\begin{array}{llll}\text { Error } \quad 4 & 1.54267 \mathrm{e}-7 & 3.8567 \mathrm{e}-8\end{array}$

C. Total 5 3.54428e-6

Means for Oneway Anova

Level Number Mean Std Error Lower 95\% Upper 95\%

$\begin{array}{llllll}\text { CC } & 3 & 0.002627 & 0.00011 & 0.00231 & 0.00294\end{array}$

$\begin{array}{llllll}\mathrm{PF} & 3 & 0.004130 & 0.00011 & 0.00382 & 0.00444\end{array}$

Std Error uses a pooled estimate of error variance 
WSRC-STI-2007-00515

Revision 0

Oneway Analysis of Ti By Digestion Type Sample=ARG-1

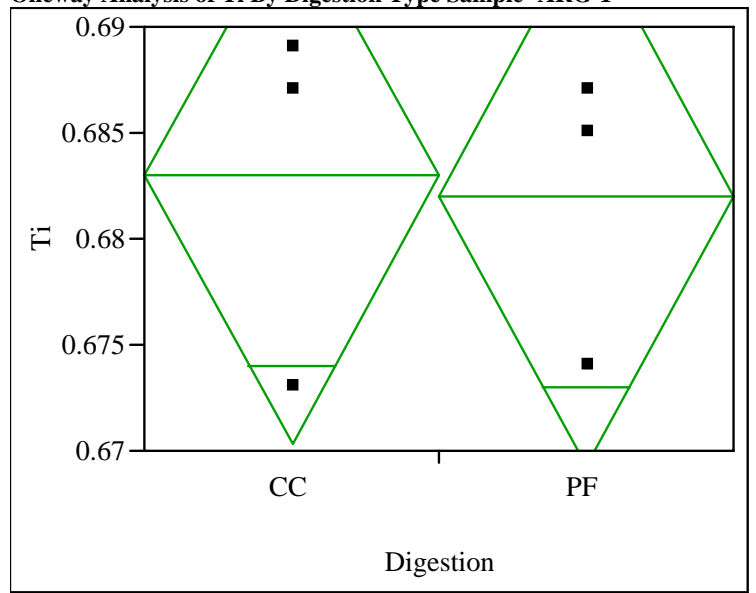

\section{Oneway Anova}

Summary of Fit

Rsquare

Adj Rsquare

0.005964

$-0.24254$

Root Mean Square Error $\quad 0.007906$

Mean of Response $\quad 0.6825$

Observations (or Sum Wgts) 6

\section{t Test}

PF-CC

Assuming equal variances

Difference $\quad-0.00100$ t Ratio $\quad-0.15492$

Std Err Dif $\quad 0.00645$ DF 4

Upper CL Dif 0.01692 Prob $>|t| \quad 0.8844$

Lower CL Dif -0.01892 Prob $>\mathrm{t} \quad 0.5578$

Confidence $\quad 0.95$ Prob $<\mathrm{t} \quad 0.4422$

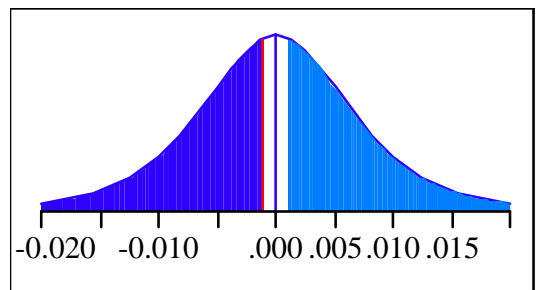

Analysis of Variance

Source DF Sum of Squares Mean Square F Ratio Prob $>$ F

Digestion $1 \quad 0.00000150$

$\begin{array}{lll}\text { Error } & 4 & 0.00025000\end{array}$

C. Total $5 \quad 0.00025150$

$1.5 \mathrm{e}-6 \quad 0.0240 \quad 0.8844$

Means for Oneway Anova

Level Number Mean Std Error Lower 95\% Upper 95\%

$\begin{array}{lllllr}\text { CC } & 3 & 0.683000 & 0.00456 & 0.67033 & 0.69567\end{array}$

$\begin{array}{llllll}\mathrm{PF} & 3 & 0.682000 & 0.00456 & 0.66933 & 0.69467\end{array}$

Std Error uses a pooled estimate of error variance
Oneway Analysis of Zn By Digestion Type Sample=ARG-1

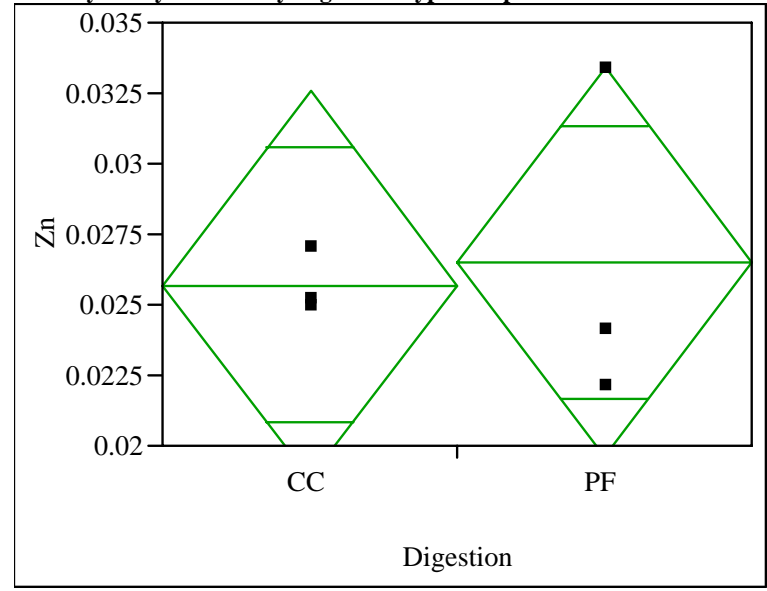

Oneway Anova

Summary of Fit

Rsquare

0.012817

Adj Rsquare

$-0.23398$

Root Mean Square Error $\quad 0.004299$

Mean of Response $\quad 0.0261$

Observations (or Sum Wgts) 6

t Test

PF-CC

Assuming equal variances

Difference $\quad 0.00080$ t Ratio 0.22789

Std Err Dif $\quad 0.00351$ DF 4

Upper CL Dif 0.01055 Prob $>|t| \quad 0.8309$

Lower CL Dif -0.00895 Prob $>t \quad 0.4155$

Confidence $\quad 0.95$ Prob $<\mathrm{t} \quad 0.5845$

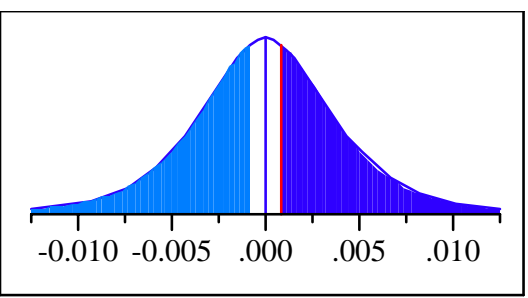

Analysis of Variance

Source DF Sum of Squares Mean Square F Ratio Prob $>$ F

$\begin{array}{llllll}\text { Digestion } & 1 & 0.00000096 & 9.6 \mathrm{e}-7 & 0.0519 & 0.8309\end{array}$

$\begin{array}{llll}\text { Error } & 4 & 0.00007394 & 0.000018\end{array}$

C. Total $5 \quad 0.00007490$

Means for Oneway Anova

Level Number Mean Std Error Lower 95\% Upper 95\%

$\begin{array}{llllll}\text { CC } & 3 & 0.025700 & 0.00248 & 0.01881 & 0.03259\end{array}$

$\begin{array}{llllll}\mathrm{PF} & 3 & 0.026500 & 0.00248 & 0.01961 & 0.03339\end{array}$

Std Error uses a pooled estimate of error variance 
WSRC-STI-2007-00515

Revision 0

Oneway Analysis of Zr By Digestion Type Sample=ARG-1

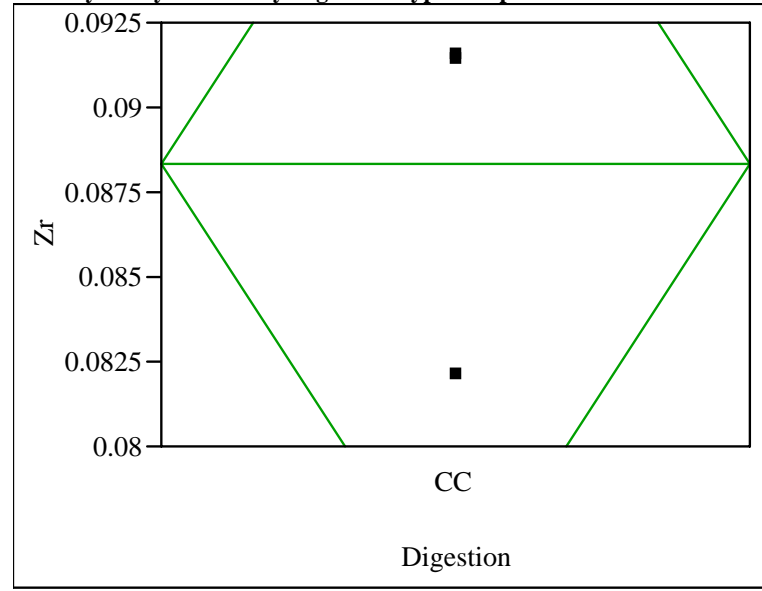

Missing Rows

3

Oneway Anova

Summary of Fit

Rsquare

Adj Rsquare

Mean of Response $\quad 0.08833$

Observations (or Sum Wgts)

Analysis of Variance

Source DF Sum of Squares Mean Square F Ratio Prob $>$ F

Digestion $\quad 0 \quad 0.00000000$

$\begin{array}{lll}\text { Error } & 2 & 0.00005829\end{array}$

C. Total $2-0.00005829$

Means for Oneway Anova

Level Number Mean Std Error Lower 95\% Upper 95\%

$\begin{array}{llllll}\text { CC } & 3 & 0.088333 & 0.00312 & 0.07492 & 0.10174\end{array}$

Std Error uses a pooled estimate of error variance
Fit Y by X Group

Oneway Analysis of Ag By Digestion Type Sample=SB4 Sim

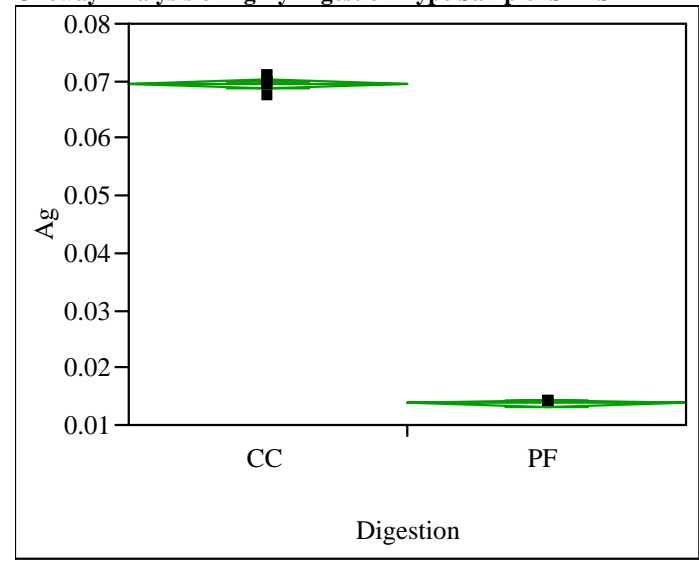

Oneway Anova

Summary of Fit

Rsquare

0.999242

Adj Rsquare

0.999166

Root Mean Square Error $\quad 0.000841$

Mean of Response

0.041575

Observations (or Sum Wgts)

12

\section{t Test}

PF-CC

Assuming equal variances

Difference $\quad-0.05575$ t Ratio $\quad-114.8$

Std Err Dif $\quad 0.00049$ DF 10

Upper CL Dif -0.05467 Prob $>|t| 0.0000$

Lower CL Dif -0.05683 Prob $>$ t 1.0000

Confidence $\quad 0.95$ Prob $<\mathrm{t} \quad 0.0000$

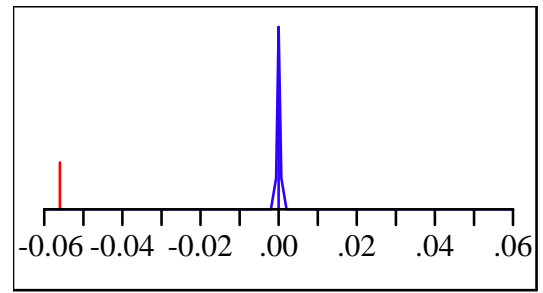

Analysis of Variance

Source DF Sum of Squares Mean Square F Ratio Prob $>$ F

$\begin{array}{llllll}\text { Digestion } & 1 & 0.00932419 & 0.009324 & 13179.06 & <.0001\end{array}$

$\begin{array}{llll}\text { Error } & 10 & 0.00000708 & 7.075 \mathrm{e}-7\end{array}$

C. Total $11 \quad 0.00933126$

Means for Oneway Anova

Level Number Mean Std Error Lower 95\% Upper 95\%

$\begin{array}{llllll}\text { CC } & 6 & 0.069450 & 0.00034 & 0.06868 & 0.07022\end{array}$

$\begin{array}{llllll}\text { PF } & 6 & 0.013700 & 0.00034 & 0.01293 & 0.01447\end{array}$

Std Error uses a pooled estimate of error variance 
WSRC-STI-2007-00515

Revision 0

This page intentionally left blank 
WSRC-STI-2007-00515

Revision 0

\section{APPENDIX B}

JMP One-Way Analysis Plots of SB4 Simulant Digested by PF and DWPF CC 
WSRC-STI-2007-00515

Revision 0

Oneway Analysis of Cd By Digestion Type Sample=SB4 Sim

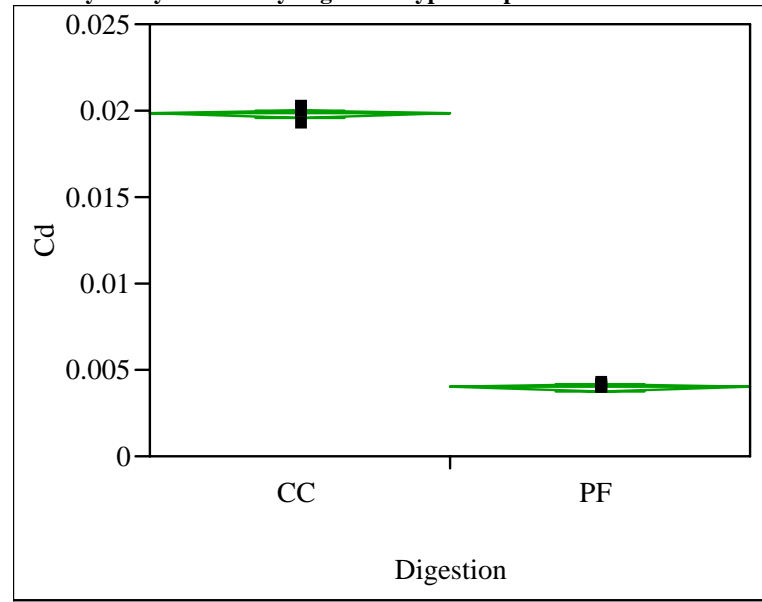

Oneway Anova

Summary of Fit

Rsquare

Adj Rsquare

0.999238

Root Mean Square Error $\quad 0.000239$

Mean of Response

Observations (or Sum Wgts) 12

t Test

PF-CC

Assuming equal variances

Difference $\quad-0.01583$ t Ratio $\quad-114.482$

Std Err Dif $\quad 0.00014$ DF 10

Upper CL Dif -0.01552 Prob $>|t| \quad 0.0000$

Lower CL Dif -0.01614 Prob $>$ t 1.0000

Confidence

0.95 Prob $<\mathrm{t}$

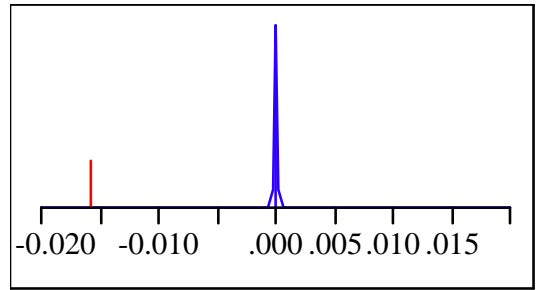

Analysis of Variance

Source DF Sum of Squares Mean Square F Ratio Prob $>$ F

$\begin{array}{llllllll}\text { Digestion } & 1 & 0.00075177 & 0.000752 & 13106.11 & <.0001\end{array}$

$\begin{array}{llll}\text { Error } & 10 & 0.00000057 & 5.736 \mathrm{e}-8\end{array}$

C. Total $11 \quad 0.00075234$

Means for Oneway Anova

Level Number Mean Std Error Lower 95\% Upper 95\%

$\begin{array}{llllll}\text { CC } & 6 & 0.019800 & 0.0001 & 0.01958 & 0.02002\end{array}$

$\begin{array}{llllll}\mathrm{PF} & 6 & 0.003970 & 0.0001 & 0.00375 & 0.00419\end{array}$

Std Error uses a pooled estimate of error variance
Oneway Analysis of Ce By Digestion Type Sample=SB4 Sim

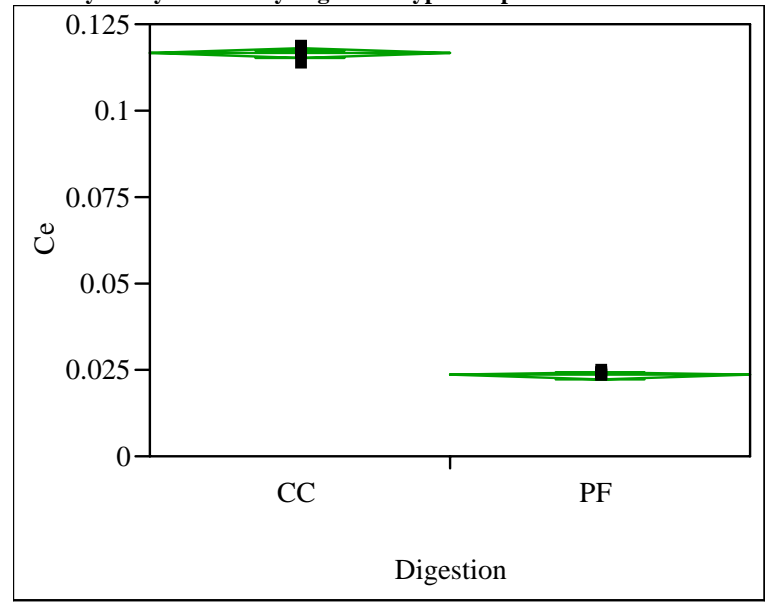

Oneway Anova

Summary of Fit

Rsquare

0.999283

Adj Rsquare

0.999212

Root Mean Square Error $\quad 0.001367$

Mean of Response

0.069917

Observations (or Sum Wgts)

12

t Test

PF-CC

Assuming equal variances

Difference $\quad-0.09317$ t Ratio $\quad-118.089$

Std Err Dif $\quad 0.00079$ DF 10

Upper CL Dif -0.09141 Prob $>|t| \quad 0.0000$

Lower CL Dif -0.09492 Prob $>$ t 1.0000

Confidence $\quad 0.95$ Prob $<\mathrm{t} \quad 0.0000$

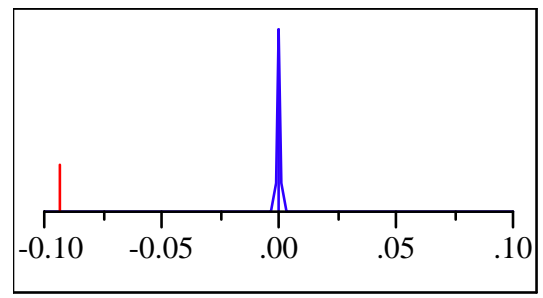

Analysis of Variance

Source DF Sum of Squares Mean Square F Ratio Prob $>$ F

$\begin{array}{lllllll}\text { Digestion } & 1 & 0.02604008 & 0.026040 & 13945.06 & <.0001\end{array}$

$\begin{array}{llll}\text { Error } & 10 & 0.00001867 & 1.867 \mathrm{e}-6\end{array}$

C. Total $11 \quad 0.02605876$

Means for Oneway Anova

Level Number Mean Std Error Lower 95\% Upper 95\%

$\begin{array}{llllll}\text { CC } & 6 & 0.116500 & 0.00056 & 0.11526 & 0.11774\end{array}$

$\begin{array}{llllll}\mathrm{PF} & 6 & 0.023333 & 0.00056 & 0.02209 & 0.02458\end{array}$

Std Error uses a pooled estimate of error variance 
WSRC-STI-2007-00515

Revision 0

Oneway Analysis of Co By Digestion Type Sample=SB4 Sim

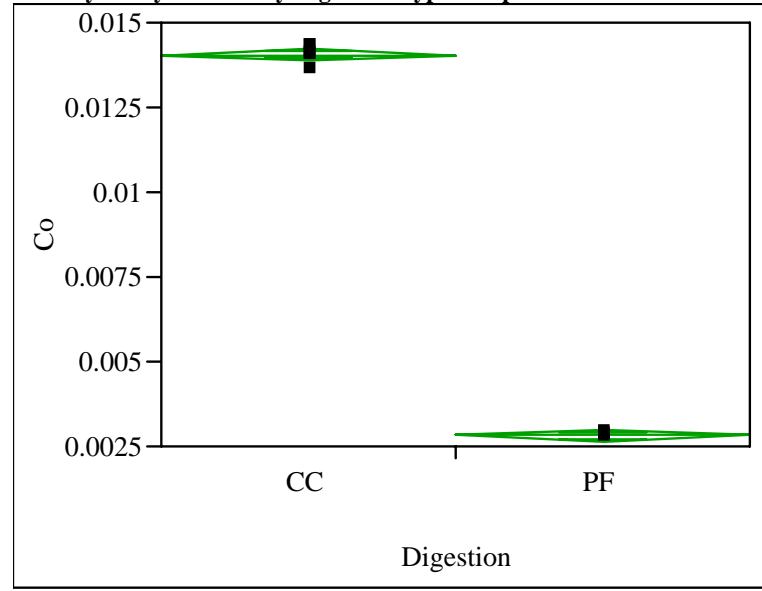

Oneway Anova

Summary of Fit

Rsquare

Adj Rsquare

Root Mean Square Error

Mean of Response

Observations (or Sum Wgts)

0.999074

0.998982

0.000187

0.008432

t Test

PF-CC

Assuming equal variances

Difference $\quad-0.01124$ t Ratio $\quad-103.893$

Std Err Dif $\quad 0.00011$ DF 10

Upper CL Dif -0.01100 Prob $>|t|<.0001$

Lower CL Dif -0.01148 Prob $>$ t 1.0000

Confidence $\quad 0.95$ Prob $<\mathrm{t} \quad<.0001$

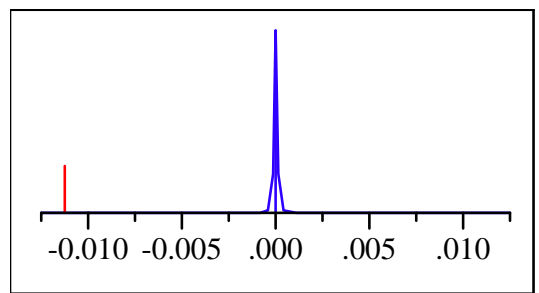

Analysis of Variance

Source DF Sum of Squares Mean Square F Ratio Prob $>$ F

$\begin{array}{llllll}\text { Digestion } & 1 & 0.00037879 & 0.000379 & 10793.73<.0001\end{array}$

$\begin{array}{llll}\text { Error } & 10 & 0.00000035 & 3.509 \mathrm{e}-8\end{array}$

C. Total $11 \quad 0.00037914$

Means for Oneway Anova

Level Number Mean Std Error Lower 95\% Upper 95\%

$\begin{array}{llllll}\text { CC } & 6 & 0.014050 & 7.65 \mathrm{e}-5 & 0.01388 & 0.01422\end{array}$

$\begin{array}{llllll}\mathrm{PF} & 6 & 0.002813 & 7.65 \mathrm{e}-5 & 0.00264 & 0.00298\end{array}$

Std Error uses a pooled estimate of error variance
Oneway Analysis of Cr By Digestion Type Sample=SB4 Sim

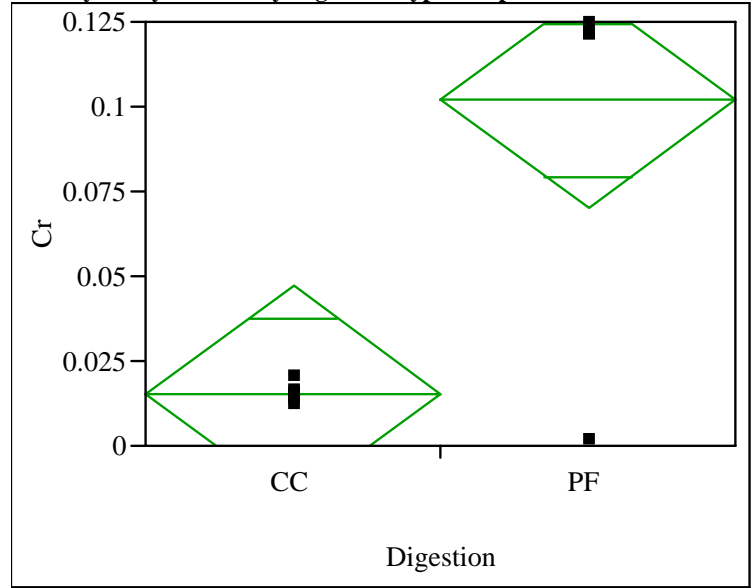

Oneway Anova

Summary of Fit

Rsquare

Adj Rsquare

0.648994

0.613893

Root Mean Square Error $\quad 0.034932$

Mean of Response

0.058511

Observations (or Sum Wgts)

12

t Test

PF-CC

Assuming equal variances

Difference $\quad 0.086722$ t Ratio 4.299942

Std Err Dif $\quad 0.020168$ DF

Upper CL Dif 0.131659 Prob $>|t| \quad 0.0016$

Lower CL Dif 0.041784 Prob $>$ t 0.0008

Confidence $\quad 0.95$ Prob $<\mathrm{t} \quad 0.9992$

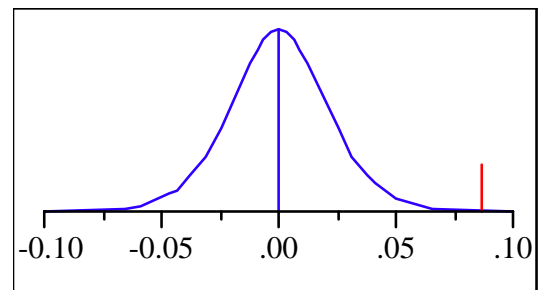

Analysis of Variance

Source DF Sum of Squares Mean Square F Ratio Prob $>$ F

$\begin{array}{llllll}\text { Digestion } & 1 & 0.02256194 & 0.022562 & 18.4895 & 0.0016\end{array}$

$\begin{array}{llll}\text { Error } & 10 & 0.01220257 & 0.001220\end{array}$

C. Total $11 \quad 0.03476451$

Means for Oneway Anova

Level Number Mean Std Error Lower 95\% Upper 95\%

$\begin{array}{llllll}\text { CC } & 6 & 0.015150 & 0.01426 & -0.0166 & 0.04693\end{array}$

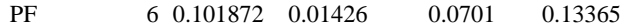

Std Error uses a pooled estimate of error variance 
WSRC-STI-2007-00515

Revision 0

Oneway Analysis of Cu By Digestion Type Sample=SB4 Sim

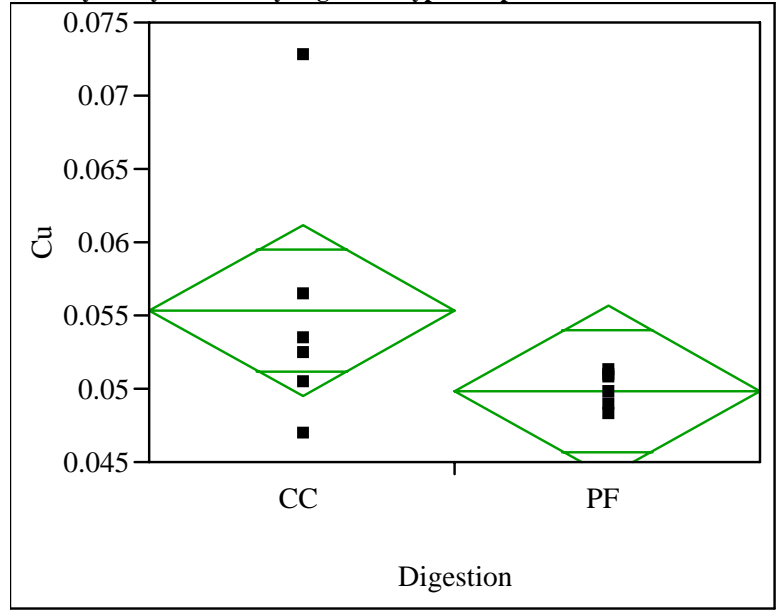

Oneway Anova

Summary of Fit

$\begin{array}{lr}\text { Rsquare } & 0.177293 \\ \text { Adj Rsquare } & 0.095022 \\ \text { Root Mean Square Error } & 0.00645 \\ \text { Mean of Response } & 0.0526\end{array}$

$\begin{array}{lr}\text { Mean of Response } & 0.0526 \\ \text { Observations (or Sum Wgts) } & 12\end{array}$

t Test

PF-CC

Assuming equal variances

Difference $\quad-0.00547$ t Ratio $\quad-1.46799$

Std Err Dif $\quad 0.00372$ DF 10

Upper CL Dif 0.00283 Prob $>|t| \quad 0.1728$

Lower CL Dif -0.01376 Prob $>\mathrm{t} \quad 0.9136$

Confidence $\quad 0.95$ Prob $<\mathrm{t} \quad 0.0864$

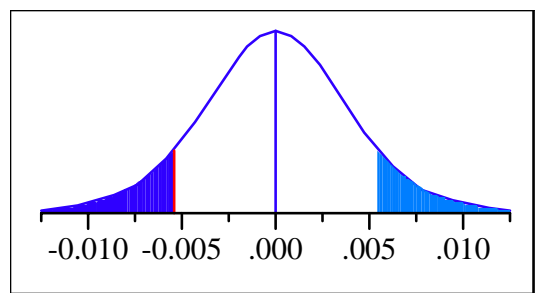

Analysis of Variance

Source DF Sum of Squares Mean Square F Ratio Prob $>$ F

$\begin{array}{llllll}\text { Digestion } & 1 & 0.00008965 & 0.000090 & 2.1550 & 0.1728\end{array}$

$\begin{array}{llll}\text { Error } & 10 & 0.00041603 & 0.000042\end{array}$

C. Total $11 \quad 0.00050568$

Means for Oneway Anova

Level Number Mean Std Error Lower 95\% Upper 95\%

$\begin{array}{llllll}\text { CC } & 6 & 0.055333 & 0.00263 & 0.04947 & 0.06120\end{array}$

$\begin{array}{llllll}\mathrm{PF} & 6 & 6.049867 & 0.00263 & 0.04400 & 0.05573\end{array}$

Std Error uses a pooled estimate of error variance
Oneway Analysis of Fe By Digestion Type Sample=SB4 Sim

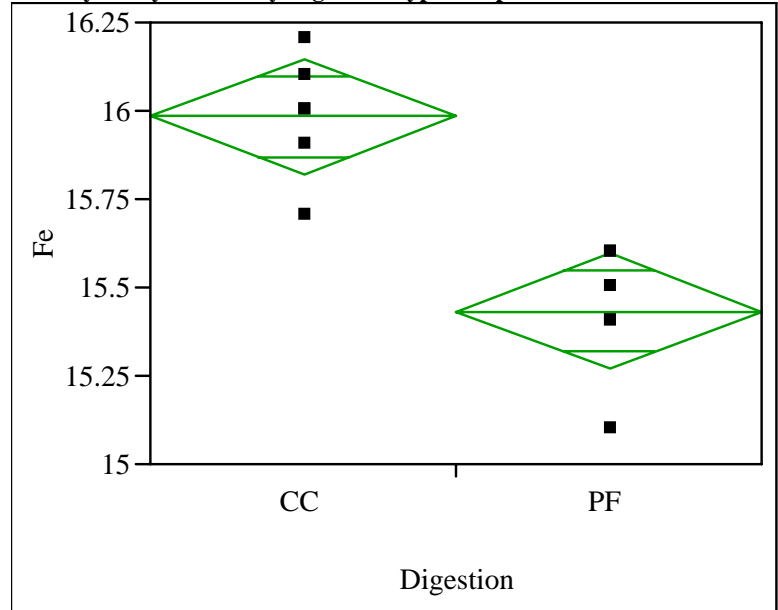

Oneway Anova

Summary of Fit

$\begin{array}{lr}\text { Rsquare } & 0.738305 \\ \text { Adj Rsquare } & 0.712136 \\ \text { Root Mean Square Error } & 0.179351 \\ \text { Mean of Response } & 15.70833 \\ \text { Observations (or Sum Wgts) } & 12 \\ & \\ \text { t Test } & \\ \text { PF-CC } & \end{array}$

Assuming equal variances

$\begin{array}{lrlr}\text { Difference } & -0.55000 & \text { t Ratio } & -5.31154 \\ \text { Std Err Dif } & 0.10355 & \text { DF } & 10 \\ \text { Upper CL Dif } & -0.31928 \text { Prob }>|t| & 0.0003 \\ \text { Lower CL Dif } & -0.78072 & \text { Prob }>t & 0.9998 \\ \text { Confidence } & 0.95 & \text { Prob }<\mathrm{t} & 0.0002\end{array}$

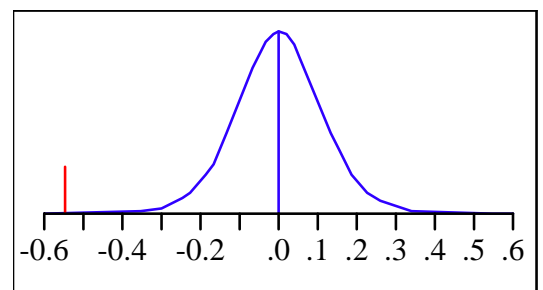

Analysis of Variance

Source DF Sum of Squares Mean Square F Ratio Prob $>$ F

$\begin{array}{llllll}\text { Digestion } & 1 & 0.9075000 & 0.907500 & 28.2124 & 0.0003\end{array}$

$\begin{array}{llll}\text { Error } & 10 & 0.3216667 & 0.032167\end{array}$

C. Total $11 \quad 1.2291667$

Means for Oneway Anova

Level Number Mean Std Error Lower 95\% Upper 95\%

$\begin{array}{llllll}\text { CC } & 6 & 15.9833 & 0.07322 & 15.820 & 16.146\end{array}$

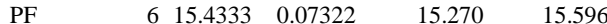

Std Error uses a pooled estimate of error variance 
WSRC-STI-2007-00515

Revision 0

Oneway Analysis of K By Digestion Type Sample=SB4 Sim

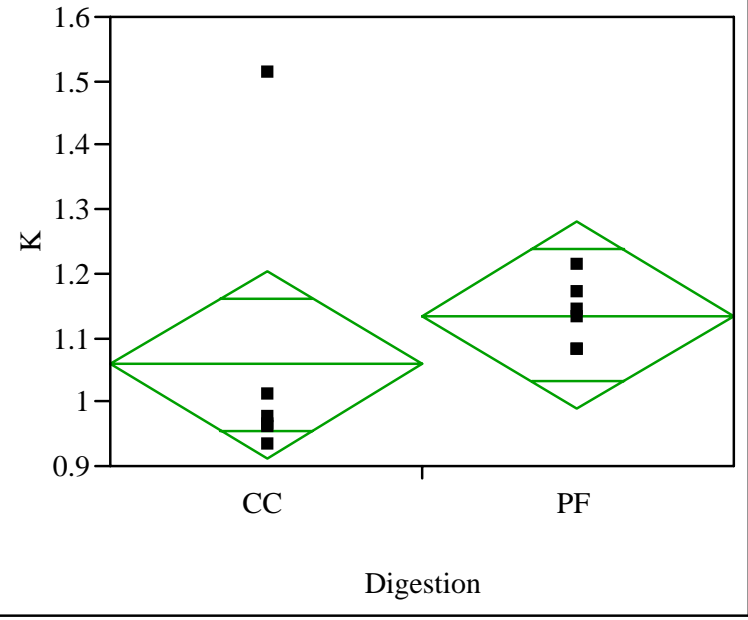

Oneway Anova

Summary of Fit

Rsquare

Adj Rsquare

0.063724

$-0.0299$

0.16166

Mean of Response

Observations (or Sum Wgts)

12

t Test

PF-CC

Assuming equal variance

Difference $\quad 0.07700$ t Ratio 0.824989

Std Err Dif 0.09333 DF 10

Upper CL Dif 0.28496 Prob $>|t| \quad 0.4286$

Lower CL Dif -0.13096 Prob $>\mathrm{t} \quad 0.2143$

$\begin{array}{lll}\text { Confidence } & 0.95 \text { Prob }<\mathrm{t} & 0.7857\end{array}$

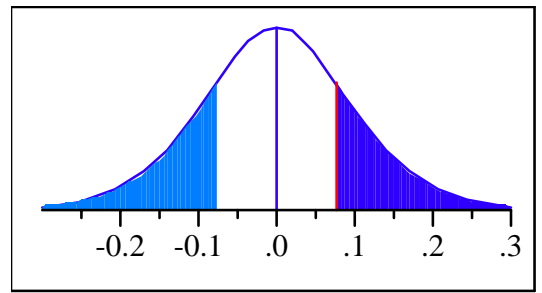

Analysis of Variance

Source DF Sum of Squares Mean Square F Ratio Prob $>$ F

$\begin{array}{lrrrrr}\text { Digestion } & 1 & 0.01778700 & 0.017787 & 0.6806 & 0.4286\end{array}$

$\begin{array}{lll}\text { Error } \quad 10 & 0.26134000\end{array}$

C. Total $11 \quad 0.27912700$

Means for Oneway Anova

Level Number Mean Std Error Lower 95\% Upper 95\%

$\begin{array}{llllll}\text { CC } & 6 & 1.05800 & 0.06600 & 0.91095 & 1.2051\end{array}$

$\begin{array}{llllll}\mathrm{PF} & 6 & 1.13500 & 0.06600 & 0.98795 & 1.2821\end{array}$

Std Error uses a pooled estimate of error variance
Oneway Analysis of La By Digestion Type Sample=SB4 Sim

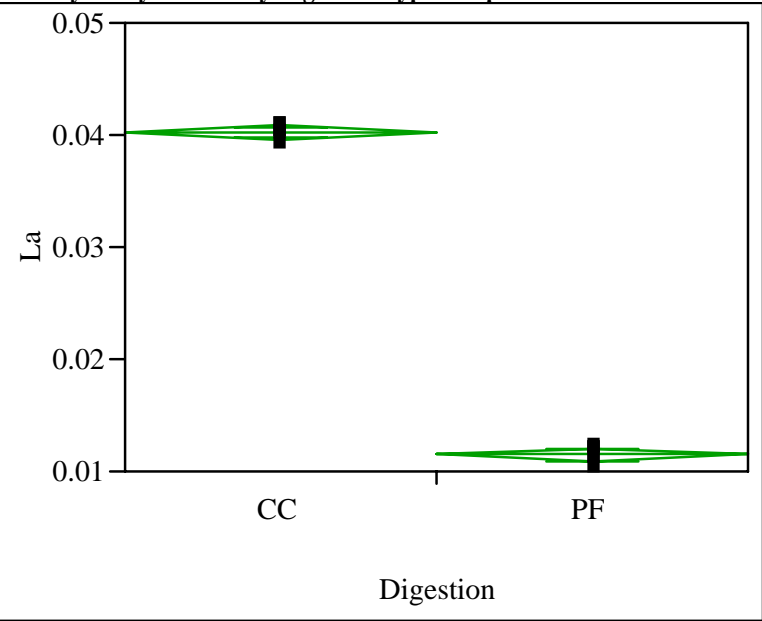

Oneway Anova

Summary of Fit

Rsquare

Adj Rsquare

Root Mean Square Error $\quad 0.000711$

Mean of Response $\quad 0.025825$

Observations (or Sum Wgts) 12

t Test

PF-CC

Assuming equal variance

Difference $\quad-0.02875$ t Ratio $\quad-70.0387$

Std Err Dif $\quad 0.00041$ DF 10

Upper CL Dif -0.02784 Prob $>|\mathrm{t}|<.0001$

Lower CL Dif -0.02966 Prob $>$ t 1.0000

Confidence $\quad 0.95$ Prob $<\mathrm{t} \quad<.0001$

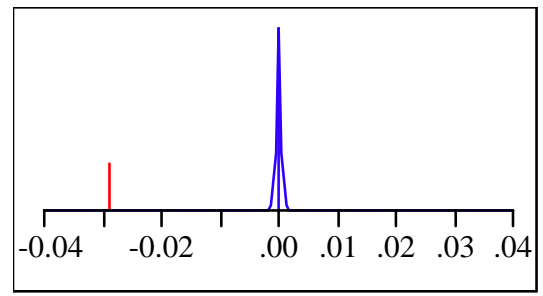

Analysis of Variance

Source DF Sum of Squares Mean Square F Ratio Prob $>$ F

$\begin{array}{llllll}\text { Digestion } & 1 & 0.00247969 & 0.002480 & 4905.415 & <.0001\end{array}$

$\begin{array}{llll}\text { Error } & 10 & 0.00000506 & 5.055 \mathrm{e}-7\end{array}$

C. Total $11 \quad 0.00248474$

Means for Oneway Anova

Level Number Mean Std Error Lower 95\% Upper 95\%

$\begin{array}{lllllr}\text { CC } & 6 & 0.040200 & 0.00029 & 0.03955 & 0.04085\end{array}$

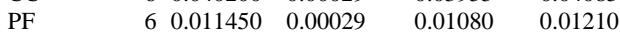

Std Error uses a pooled estimate of error variance 
WSRC-STI-2007-00515

Revision 0

Oneway Analysis of Li By Digestion Type Sample=SB4 Sim

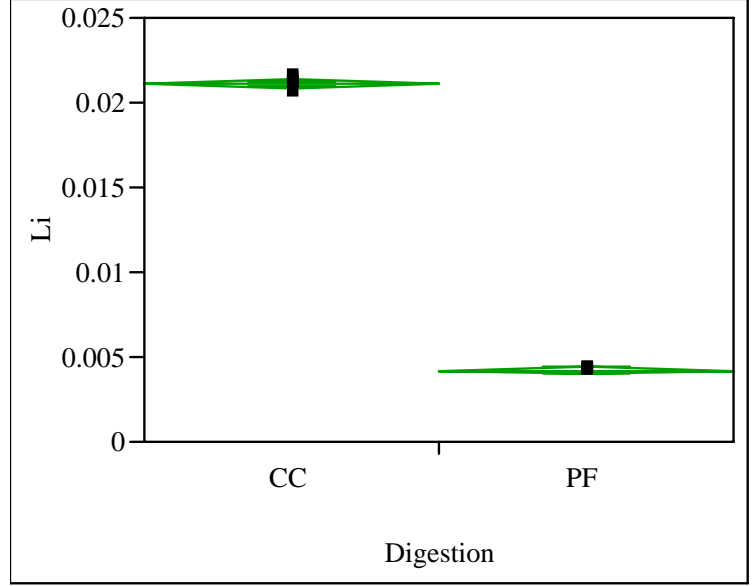

Oneway Anova

Summary of Fit

Rsquare

Adj Rsquare

0.999245

Mean Square Error

Mean of Response $\quad 0.012676$

Observations (or Sum Wgts) 12

t Test

PF-CC

Assuming equal variances

Difference $\quad-0.01688$ t Ratio $\quad-115.035$

Std Err Dif $\quad 0.00015$ DF 10

Upper CL Dif -0.01655 Prob $>|t| \quad 0.0000$

Lower CL Dif -0.01721 Prob $>\mathrm{t} 1.0000$

Confidence $\quad 0.95$ Prob $<\mathrm{t} \quad 0.0000$

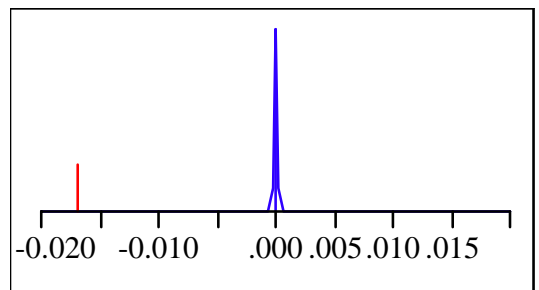

Analysis of Variance

Source DF Sum of Squares Mean Square F Ratio Prob $>$ F

Digestion $1 \quad 0.00085497 \quad 0.00085513233 .15<.0001$

$\begin{array}{llll}\text { Error } & 10 & 0.00000065 & 6.461 \mathrm{e}-8\end{array}$

C. Total $11 \quad 0.00085562$

Means for Oneway Anova

Level Number Mean Std Error Lower 95\% Upper 95\%

$\begin{array}{llllll}\text { CC } & 6 & 0.021117 & 0.00010 & 0.02089 & 0.02135\end{array}$

$\begin{array}{llllll}\mathrm{PF} & 6 & 0.004235 & 0.00010 & 0.00400 & 0.00447\end{array}$

Std Error uses a pooled estimate of error variance
Oneway Analysis of Mg By Digestion Type Sample=SB4 Sim

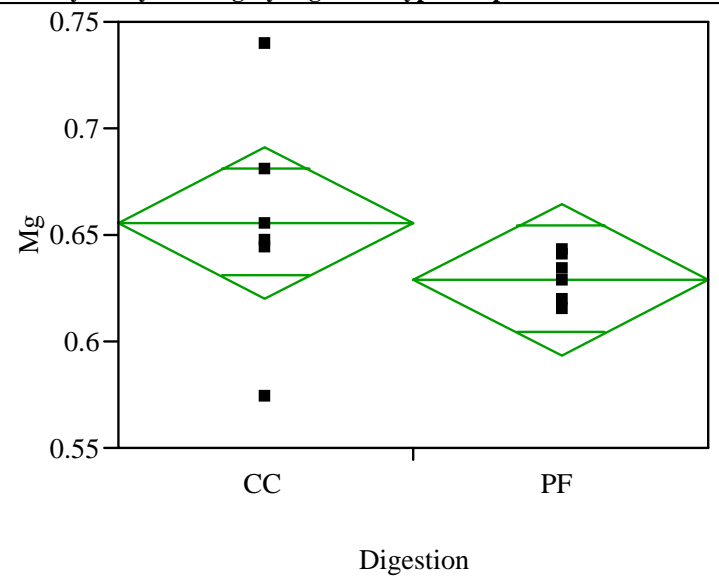

Oneway Anova

Summary of Fit

$\begin{array}{lr}\text { Rsquare } & 0.122798 \\ \text { Adj Rsquare } & 0.035078 \\ \text { Root Mean Square Error } & 0.039038 \\ \text { Mean of Response } & 0.642667 \\ \text { Observations (or Sum Wgts) } & 12 \\ & \\ \text { t Test } & \\ \text { PF-CC } & \end{array}$

Assuming equal variances

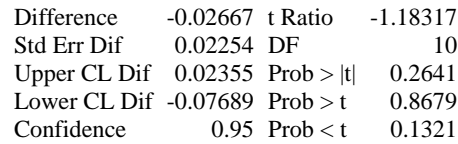

Confidence $\quad 0.95$ Prob $<\mathrm{t} \quad 0.1321$

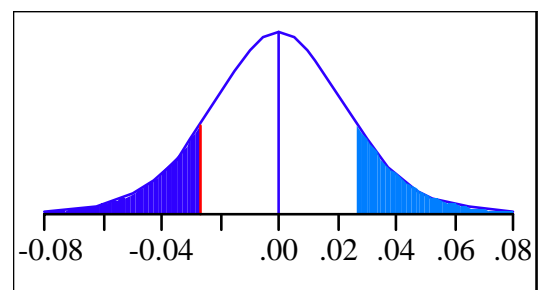

Analysis of Variance

Source DF Sum of Squares Mean Square F Ratio Prob $>$ F

$\begin{array}{llllll}\text { Digestion } & 1 & 0.00213333 & 0.002133 & 1.3999 & 0.2641\end{array}$

$\begin{array}{llll}\text { Error } & 10 & 0.01523933 & 0.001524\end{array}$

C. Total $11 \quad 0.01737267$

Means for Oneway Anova

Level Number Mean Std Error Lower 95\% Upper 95\%

$\begin{array}{llllll}\text { CC } & 6 & 0.656000 & 0.01594 & 0.62049 & 0.69151\end{array}$

$\begin{array}{llllll}\mathrm{PF} & 6 & 0.629333 & 0.01594 & 0.59382 & 0.66484\end{array}$

Std Error uses a pooled estimate of error variance 
WSRC-STI-2007-00515

Revision 0

Oneway Analysis of Mn By Digestion Type Sample=SB4 Sim

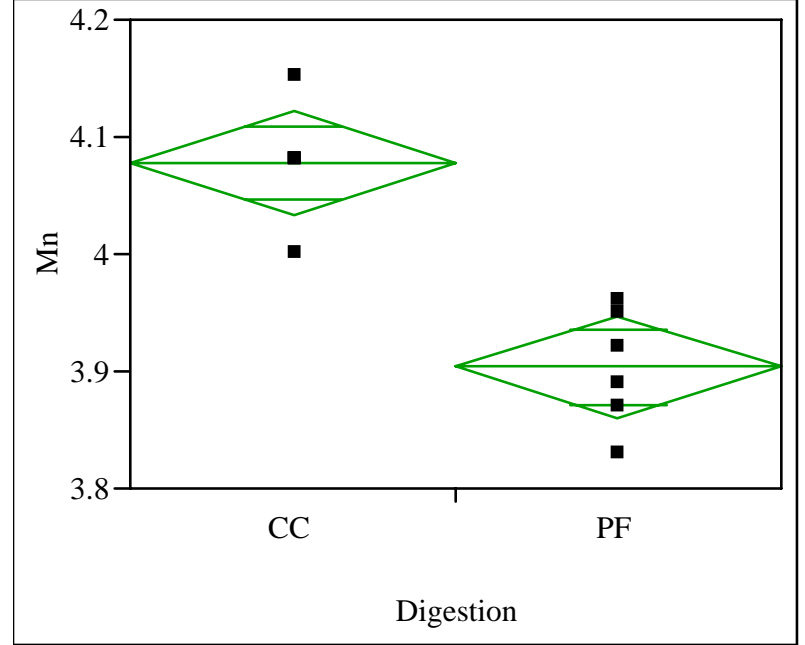

Oneway Anova

Summary of Fit

Rsquare

Adj Rsquare

0.795512

0.775063

0.048597

Mean of Response 3.990833

Observations (or Sum Wgts) $\quad 12$

t Test

PF-CC

Assuming equal variances

Difference $\quad-0.17500$ t Ratio $\quad-6.2372$

Std Err Dif 0.02806 DF

Upper CL Dif -0.11248 Prob $>|t|<.0001$

Lower CL Dif -0.23752 Prob $>$ t 1.0000

Confidence $\quad 0.95$ Prob $<\mathrm{t} \quad<.0001$

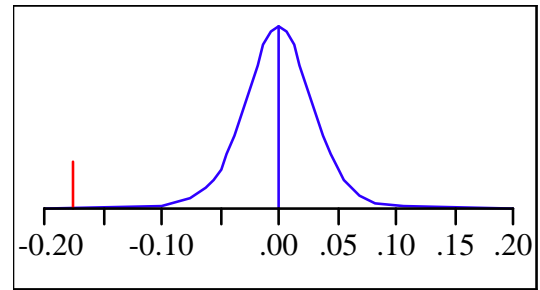

Analysis of Variance

Source DF Sum of Squares Mean Square F Ratio Prob $>$ F

Digestion $1 \quad 0.09187500 \quad 0.09187538 .9026<.0001$

$\begin{array}{llll}\text { Error } & 10 & 0.02361667 & 0.002362\end{array}$

C. Total $11 \quad 0.11549167$

Means for Oneway Anova

Level Number Mean Std Error Lower 95\% Upper 95\%

$\begin{array}{lllllr}\text { CC } & 6 & 4.07833 & 0.01984 & 4.0341 & 4.1225\end{array}$

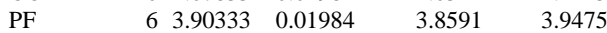

Std Error uses a pooled estimate of error variance
Oneway Analysis of Mo By Digestion Type Sample=SB4 Sim

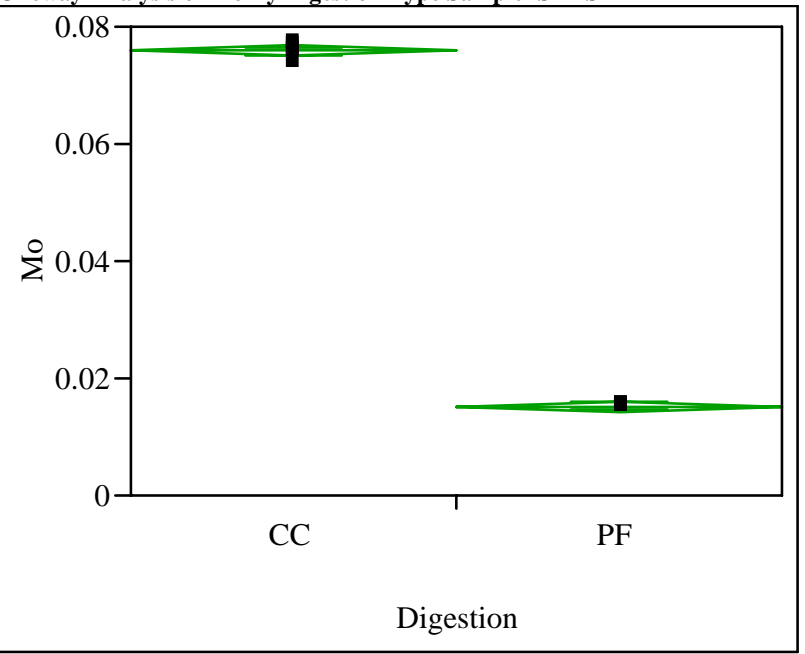

Oneway Anova

Summary of Fit

Rsquare

0.999188

Adj Rsquare

0.999107

Root Mean Square Error $\quad 0.000948$

Mean of Response

0.045567

Observations (or Sum Wgts)

12

t Test

PF-CC

Assuming equal variances

Difference $\quad-0.06073$ t Ratio $\quad-110.924$

Std Err Dif $\quad 0.00055$ DF 10

Upper CL Dif -0.05951 Prob $>|t| \quad 0.0000$

Lower CL Dif -0.06195 Prob $>\mathrm{t} \quad 1.0000$

Confidence $\quad 0.95$ Prob $<\mathrm{t} \quad 0.0000$

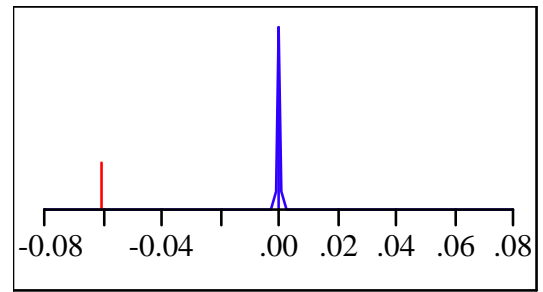

Analysis of Variance

Source DF Sum of Squares Mean Square F Ratio Prob $>$ F

Digestion $1 \quad 0.01106561 \quad 0.01106612304 .24<.0001$

$\begin{array}{llll}\text { Error } & 10 & 0.00000899 & 8.993 \mathrm{e}-7\end{array}$

C. Total $11 \quad 0.01107461$

Means for Oneway Anova

Level Number Mean Std Error Lower 95\% Upper 95\%

$\begin{array}{llllll}\text { CC } & 6 & 0.075933 & 0.00039 & 0.07507 & 0.07680\end{array}$

$\begin{array}{llllll}\mathrm{PF} & 6 & 0.015200 & 0.00039 & 0.01434 & 0.01606\end{array}$

Std Error uses a pooled estimate of error variance 
WSRC-STI-2007-00515

Revision 0

Oneway Analysis of Na By Digestion Type Sample=SB4 Sim

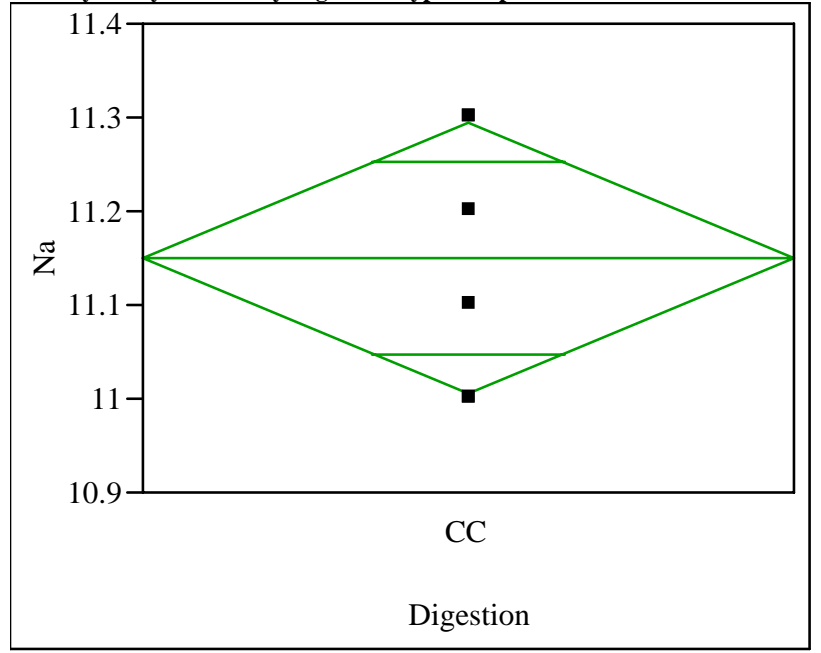

Missing Rows

Oneway Anova

Summary of Fit

Rsquare

Adj Rsquare

Root Mean Square Error $\quad 0.13784$

Mean of Response 11.15

Observations (or Sum Wgts) 6

Analysis of Variance

Source DF Sum of Squares Mean Square F Ratio Prob $>$ F

Digestion $0 \quad 0.00000000$

$\begin{array}{lll}\text { Error } & 5 & 0.09500000\end{array}$

$\begin{array}{llll}\text { C. Total } & 5 & 0.09500000 & 0.019000\end{array}$

Means for Oneway Anova

Level Number Mean Std Error Lower 95\% Upper 95\%

$\begin{array}{llllll}\text { CC } & 6 & 11.1500 & 0.05627 & 11.005 & 11.295\end{array}$

Std Error uses a pooled estimate of error variance 
WSRC-STI-2007-00515

Revision 0

Oneway Analysis of Nb By Digestion Type Sample=SB4 Sim

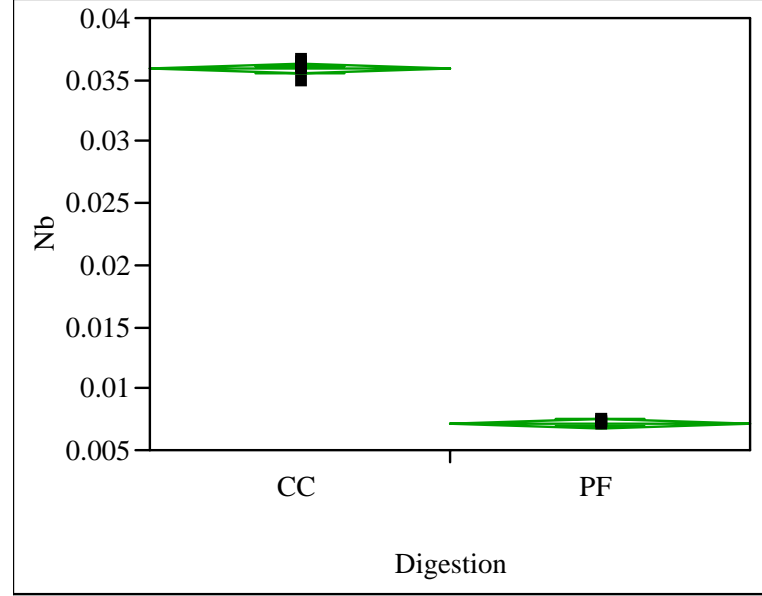

Oneway Anova

Summary of Fit

$\begin{array}{lr}\text { Rsquare } & 0.999216 \\ \text { Adj Rsquare } & 0.999137 \\ \text { Root Mean Square Error } & 0.00044 \\ \text { Mean of Response } & 0.021534 \\ \text { Observations (or Sum Wgts) } & 12\end{array}$

t Test

PF-CC

Assuming equal variances

Difference $\quad-0.02870$ t Ratio $\quad-112.869$

Std Err Dif 0.00025 DF 10

Upper CL Dif -0.02813 Prob $>|t| \quad 0.0000$

Lower CL Dif -0.02926 Prob $>$ t 1.0000

$\begin{array}{lll}\text { Confidence } & 0.95 \text { Prob }<\mathrm{t} \quad 0.0000\end{array}$

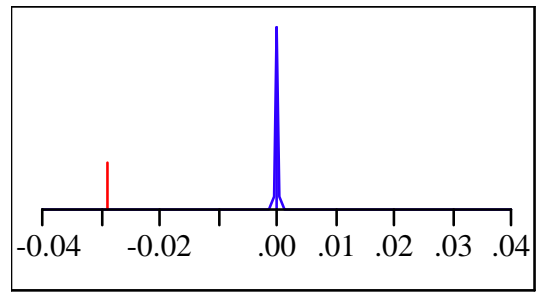

Analysis of Variance

Source DF Sum of Squares Mean Square F Ratio Prob $>$ F

$\begin{array}{llllll}\text { Digestion } & 1 & 0.00247078 & 0.002471 & 12739.39 & <.0001\end{array}$

$\begin{array}{llll}\text { Error } & 10 & 0.00000194 & 1.939 \mathrm{e}-7\end{array}$

C. Total $11 \quad 0.00247272$

Means for Oneway Anova

Level Number Mean Std Error Lower 95\% Upper 95\%

$\begin{array}{llllll}\text { CC } & 6 & 0.035883 & 0.00018 & 0.03548 & 0.03628\end{array}$

$\begin{array}{llllll}\mathrm{PF} & 6 & 0.007185 & 0.00018 & 0.00678 & 0.00759\end{array}$

Std Error uses a pooled estimate of error variance
Oneway Analysis of Nd By Digestion Type Sample=SB4 Sim

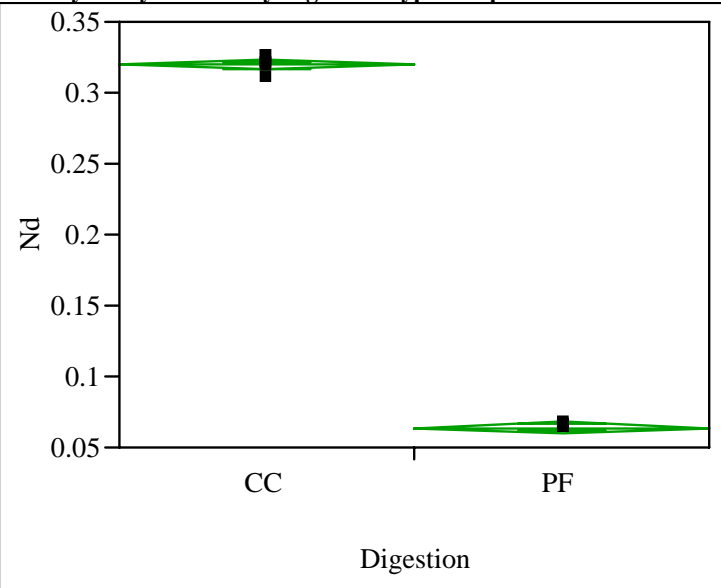

Oneway Anova

Summary of Fit

Rsquare

Adj Rsquare

0.999188

0.999106

0.003994

Mean of Response 0.191967

Observations (or Sum Wgts)

12

t Test

PF-CC

Assuming equal variances

$\begin{array}{lrlr}\text { Difference } & -0.25573 \text { t Ratio } & -110.905 \\ \text { Std Err Dif } & 0.00231 & \text { DF } & 10 \\ \text { Upper CL Dif } & -0.25060 \text { Prob }>|t| & 0.0000 \\ \text { Lower CL Dif } & -0.26087 \text { Prob }>\text { t } & 1.0000 \\ \text { Confidence } & 0.95 & \text { Prob }<t & 0.0000\end{array}$

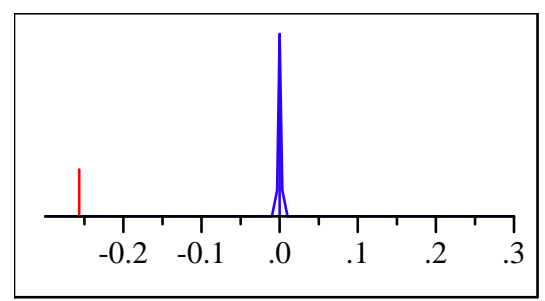

Analysis of Variance

Source DF Sum of Squares Mean Square F Ratio Prob $>$ F

$\begin{array}{llllll}\text { Digestion } & 1 & 0.19619861 & 0.196199 & 12299.83 & <.0001\end{array}$

$\begin{array}{llll}\text { Error } & 10 & 0.00015951 & 0.000016\end{array}$

C. Total $11 \quad 0.19635813$

Means for Oneway Anova

Level Number Mean Std Error Lower 95\% Upper 95\%

$\begin{array}{llllll}\text { CC } & 6 & 0.319833 & 0.00163 & 0.31620 & 0.32347\end{array}$

$\begin{array}{llllll}\mathrm{PF} & 6 & 0.064100 & 0.00163 & 0.06047 & 0.06773\end{array}$

Std Error uses a pooled estimate of error variance 
WSRC-STI-2007-00515

Revision 0

Oneway Analysis of Ni By Digestion Type Sample=SB4 Sim

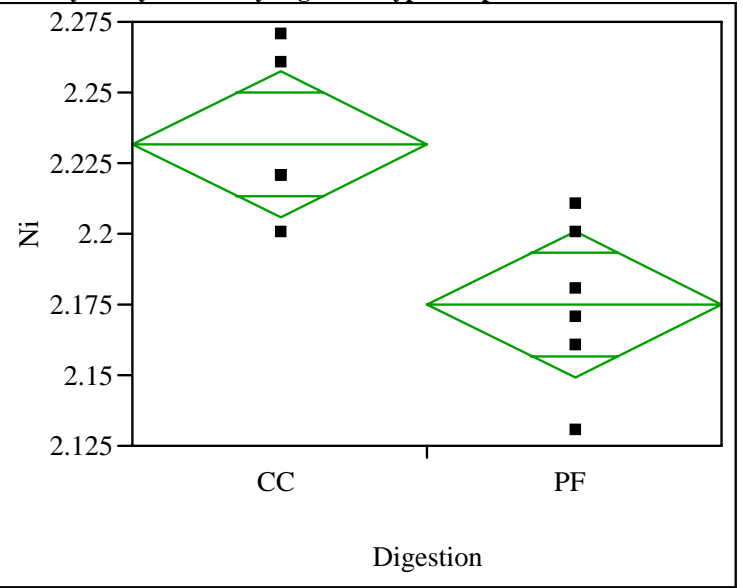

Oneway Anova

Summary of Fit

Rsquare

Adj Rsquare

Root Mean Square Error

Mean of Response

Observations (or Sum Wgts) 12

\section{t Test}

PF-CC

Assuming equal variances

Difference $\quad-0.05667$ t Ratio $\quad-3.50683$

Std Err Dif $\quad 0.01616$ DF 10

Upper CL Dif -0.02066 Prob $>|t| \quad 0.0057$

Lower CL Dif -0.09267 Prob $>t \quad 0.9972$

Confidence $\quad 0.95$ Prob $<\mathrm{t} \quad 0.0028$

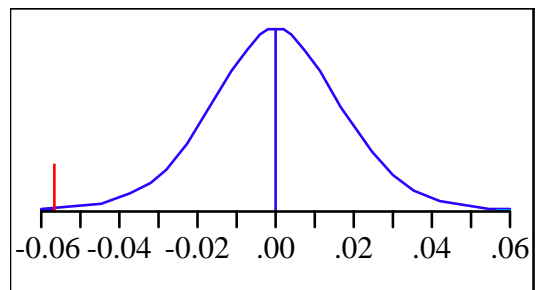

Analysis of Variance

Source DF Sum of Squares Mean Square F Ratio Prob $>$ F

$\begin{array}{lllllll}\text { Digestion } & 1 & 0.00963333 & 0.009633 & 12.2979 & 0.0057\end{array}$

$\begin{array}{lll}\text { Error } \quad 10 & 0.00783333\end{array}$

$\begin{array}{lll}\text { C. Total } & 11 & 0.01746667\end{array}$

Means for Oneway Anova

Level Number Mean Std Error Lower 95\% Upper 95\%

$\begin{array}{llllll}\text { CC } & 6 & 2.23167 & 0.01143 & 2.2062 & 2.2571\end{array}$

$\begin{array}{llllll}\mathrm{PF} & 6 & 2.17500 & 0.01143 & 2.1495 & 2.2005\end{array}$

Std Error uses a pooled estimate of error variance
Oneway Analysis of P By Digestion Type Sample=SB4 Sim

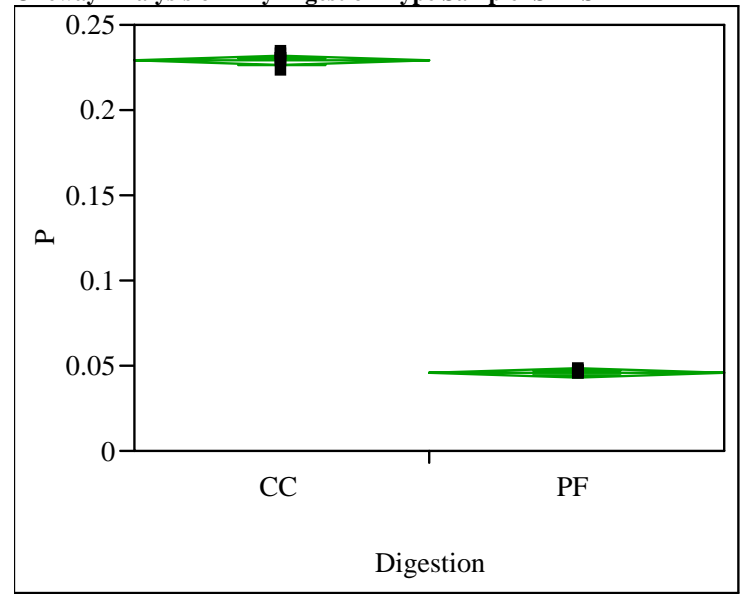

Oneway Anova

Summary of Fit

$\begin{array}{lr}\text { Rsquare } & 0.999211 \\ \text { Adj Rsquare } & 0.999132 \\ \text { Root Mean Square Error } & 0.002817 \\ \text { Mean of Response } & 0.137325 \\ \text { Observations (or Sum Wgts) } & 12 \\ & \\ \text { t Test } & \\ \text { PF-CC } & \end{array}$

Assuming equal variances
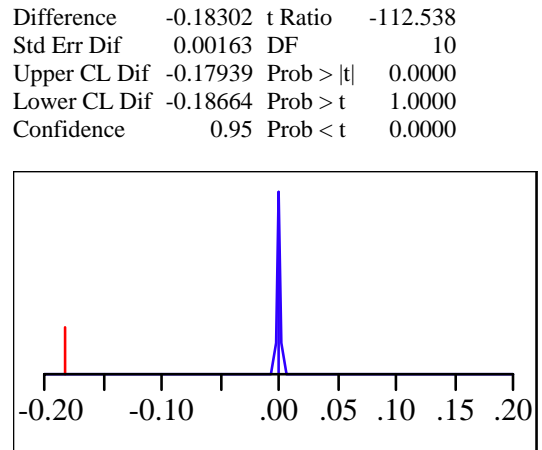

Analysis of Variance

Source DF Sum of Squares Mean Square F Ratio Prob > F

$\begin{array}{llllll}\text { Digestion } & 1 & 0.10048530 & 0.100485 & 12664.88 & <.0001\end{array}$

$\begin{array}{llll}\text { Error } & 10 & 0.00007934 & 7.934 \mathrm{e}-6\end{array}$

C. Total $11 \quad 0.10056464$

Means for Oneway Anova

Level Number Mean Std Error Lower 95\% Upper 95\%

$\begin{array}{llllll}\text { CC } & 6 & 0.228833 & 0.00115 & 0.22627 & 0.23140\end{array}$

$\begin{array}{llllll}\text { PF } & 6 & 0.045817 & 0.00115 & 0.04325 & 0.04838\end{array}$

Std Error uses a pooled estimate of error variance 
WSRC-STI-2007-00515

Revision 0

Oneway Analysis of Pb By Digestion Type Sample=SB4 Sim

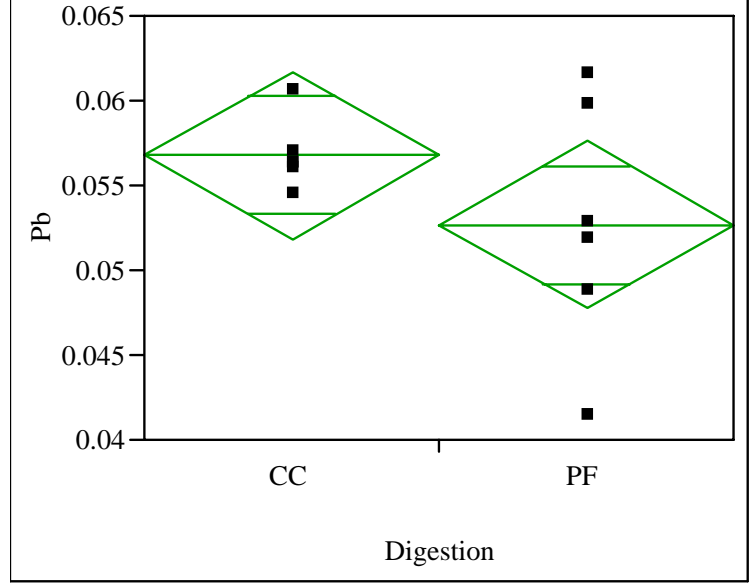

Oneway Anova

Summary of Fit

Rsquare

Adj Rsquare

Root Mean Square Error

Mean of Response

0.061221

0.005397

0.054708

Observations (or Sum Wgts)

12

t Test

PF-CC

Assuming equal variances

Difference $\quad-0.00408$ t Ratio -1.31048

Std Err Dif $\quad 0.00312$ DF 10

Upper CL Dif 0.00286 Prob $>|t| \quad 0.2193$

Lower CL Dif -0.01103 Prob $>t \quad 0.8903$

Confidence $\quad 0.95$ Prob $<\mathrm{t} \quad 0.1097$

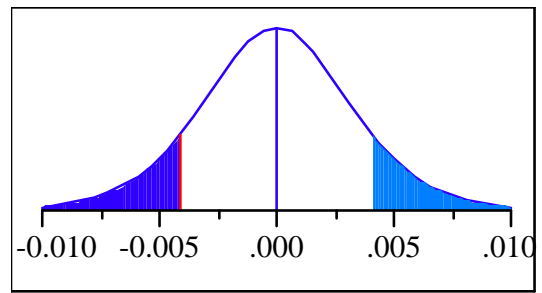

Analysis of Variance

Source DF Sum of Squares Mean Square F Ratio Prob $>$ F

$\begin{array}{llllll}\text { Digestion } & 1 & 0.00005002 & 0.000050 & 1.7173 & 0.2193\end{array}$

$\begin{array}{lll}\text { Error } & 10 & 0.00029127\end{array}$

C. Total $11 \quad 0.00034129$

Means for Oneway Anova

Level Number Mean Std Error Lower 95\% Upper 95\%

$\begin{array}{lllllr}\text { CC } & 6 & 0.056750 & 0.00220 & 0.05184 & 0.06166\end{array}$

$\begin{array}{llllll}\mathrm{PF} & 6 & 0.052667 & 0.00220 & 0.04776 & 0.05758\end{array}$

Std Error uses a pooled estimate of error variance
Oneway Analysis of Re By Digestion Type Sample=SB4 Sim

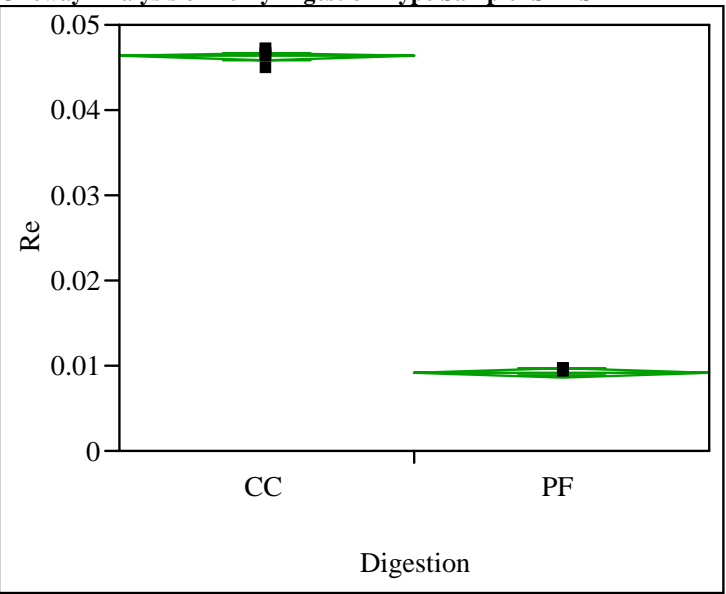

Oneway Anova

Summary of Fit

$\begin{array}{lr}\text { Rsquare } & 0.999163 \\ \text { Adj Rsquare } & 0.999079 \\ \text { Root Mean Square Error } & 0.000586 \\ \text { Mean of Response } & 0.02776 \\ \text { Observations (or Sum Wgts) } & 12 \\ & \\ \text { t Test } & \\ \text { PF-CC }\end{array}$

Assuming equal variances

$\begin{array}{lrlr}\text { Difference } & -0.03698 \text { t Ratio } & -109.245 \\ \text { Std Err Dif } & 0.00034 \text { DF } & 10 \\ \text { Upper CL Dif } & -0.03623 \text { Prob }>|t| & 0.0000 \\ \text { Lower CL Dif } & -0.03773 \text { Prob }>t & 1.0000 \\ \text { Confidence } & 0.95 \text { Prob }<\mathrm{t} & 0.0000\end{array}$

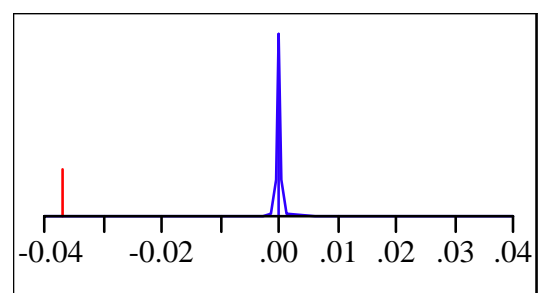

Analysis of Variance

Source DF Sum of Squares Mean Square F Ratio Prob $>$ F

$\begin{array}{lllllll}\text { Digestion } & 1 & 0.00410256 & 0.004103 & 11934.38 & <.0001\end{array}$

$\begin{array}{llll}\text { Error } & 10 & 0.00000344 & 3.438 \mathrm{e}-7\end{array}$

C. Total $11 \quad 0.00410600$

Means for Oneway Anova

Level Number Mean Std Error Lower 95\% Upper 95\%

$\begin{array}{llllll}\text { CC } & 6 & 0.046250 & 0.00024 & 0.04572 & 0.04678\end{array}$

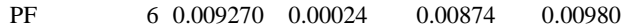

Std Error uses a pooled estimate of error variance 
WSRC-STI-2007-00515

Revision 0

Oneway Analysis of S By Digestion Type Sample=SB4 Sim

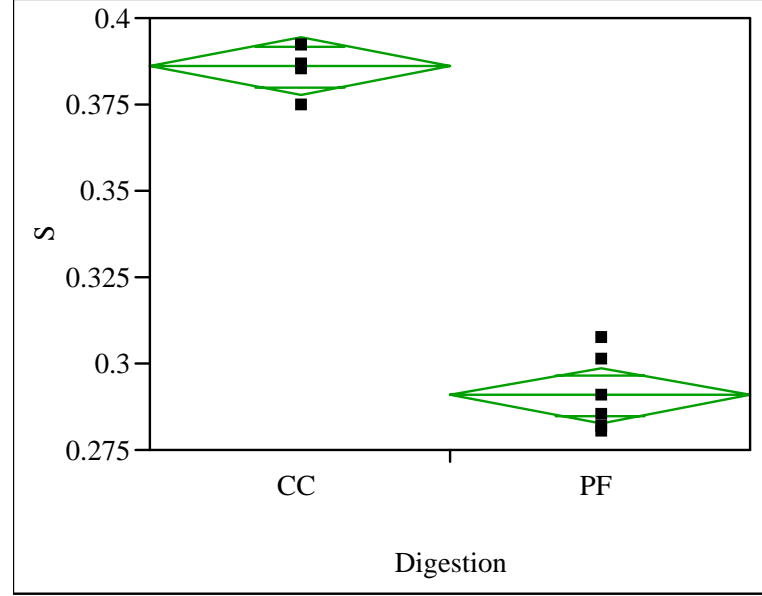

Oneway Anova

Summary of Fit

$\begin{array}{lr}\text { Rsquare } & 0.970351 \\ \text { Adj Rsquare } & 0.967387 \\ \text { Root Mean Square Error } & 0.009111 \\ \text { Mean of Response } & 0.33825 \\ \text { Observations (or Sum Wgts) } & 12\end{array}$

Observations (or Sum Wgts)

t Test

PF-CC

Assuming equal variances

Difference $\quad-0.09517$ t Ratio $\quad-18.091$

Std Err Dif $\quad 0.00526$ DF 10

Upper CL Dif -0.08345 Prob $>|t|<.0001$

Lower CL Dif -0.10689 Prob $>$ t 1.0000

Confidence $\quad 0.95$ Prob $<\mathrm{t} \quad<.0001$

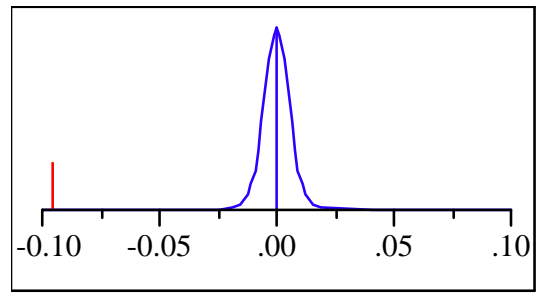

Analysis of Variance

Source DF Sum of Squares Mean Square F Ratio Prob $>$ F

$\begin{array}{lllllll}\text { Digestion } & 1 & 0.02717008 & 0.027170 & 327.2847 & <.0001\end{array}$

$\begin{array}{llll}\text { Error } & 10 & 0.00083017 & 0.000083\end{array}$

C. Total $11 \quad 0.02800025$

Means for Oneway Anova

Level Number Mean Std Error Lower 95\% Upper 95\%

$\begin{array}{llllll}\text { CC } & 6 & 0.385833 & 0.00372 & 0.37755 & 0.39412\end{array}$

$\begin{array}{llllll}\mathrm{PF} & 6 & 0.290667 & 0.00372 & 0.28238 & 0.29895\end{array}$

Std Error uses a pooled estimate of error variance
Oneway Analysis of Si By Digestion Type Sample=SB4 Sim

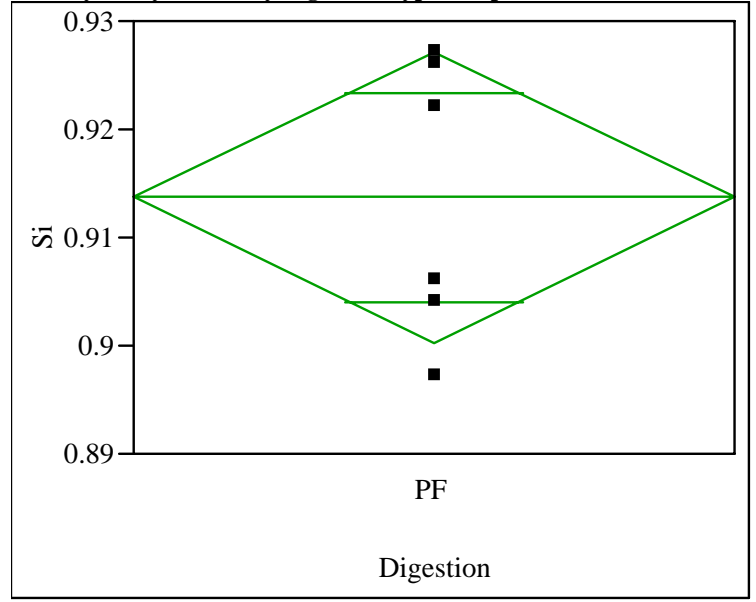

Missing Rows

6

Oneway Anova

Summary of Fit

$\begin{array}{lr}\text { Rsquare } & 0 \\ \text { Adj Rsquare } & 0 \\ \text { Root Mean Square Error } & 0.012879 \\ \text { Mean of Response } & 0.913667 \\ \text { Observations (or Sum Wgts) } & 6\end{array}$

Analysis of Variance

Source DF Sum of Squares Mean Square F Ratio Prob $>$ F

Digestion $0 \quad 0.00000000$

$\begin{array}{llll}\text { Error } & 5 & 0.00082933 & 0.000166\end{array}$

C. Total $5 \quad 0.00082933$

Means for Oneway Anova

Level Number Mean Std Error Lower 95\% Upper 95\%

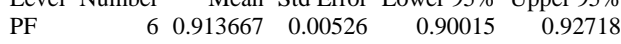

Std Error uses a pooled estimate of error variance 
WSRC-STI-2007-00515

Revision 0

Oneway Analysis of Sn By Digestion Type Sample=SB4 Sim

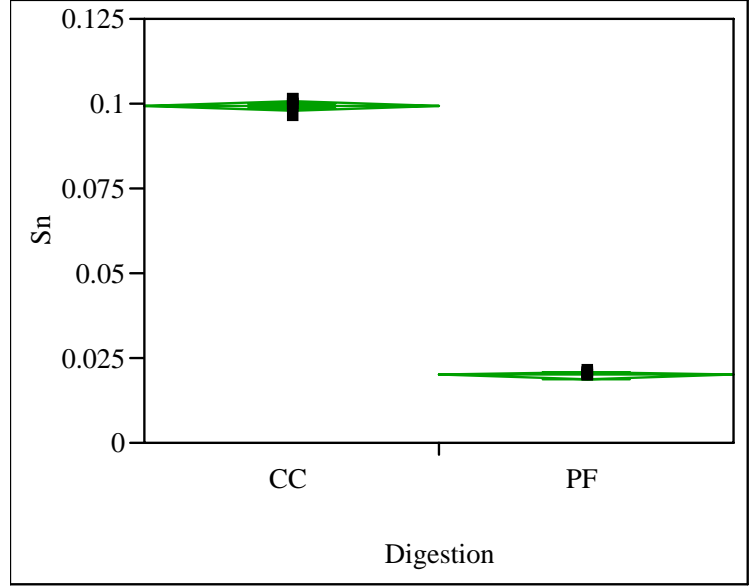

Oneway Anova

Summary of Fit

Rsquare

Adj Rsquare

Root Mean Square Error

Mean of Response

Observations (or Sum Wgts)

0.999062

0.998969

0.001331

0.059517

t Test

PF-CC

Assuming equal variances

Difference $\quad-0.07930$ t Ratio $\quad-103.22$

Std Err Dif $\quad 0.00077$ DF 10

Upper CL Dif -0.07759 Prob $>|t|<.0001$

Lower CL Dif -0.08101 Prob $>\mathrm{t} \quad 1.0000$

Confidence $\quad 0.95$ Prob $<\mathrm{t} \quad<.0001$

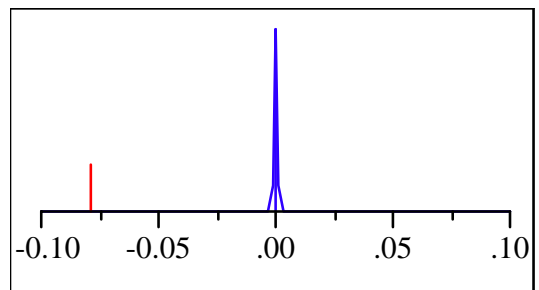

Analysis of Variance

Source DF Sum of Squares Mean Square F Ratio Prob $>$ F

$\begin{array}{llllll}\text { Digestion } & 1 & 0.01886547 & 0.018865 & 10654.44 & <.0001\end{array}$

$\begin{array}{llll}\text { Error } & 10 & 0.00001771 & 1.771 \mathrm{e}-6\end{array}$

C. Total $11 \quad 0.01888318$

Means for Oneway Anova

Level Number Mean Std Error Lower 95\% Upper 95\%

$\begin{array}{llllll}\text { CC } & 6 & 0.099167 & 0.00054 & 0.09796 & 0.10038\end{array}$

$\begin{array}{llllll}\mathrm{PF} & 6 & 6.019867 & 0.00054 & 0.01866 & 0.02108\end{array}$

Std Error uses a pooled estimate of error variance
Oneway Analysis of Sr By Digestion Type Sample=SB4 Sim

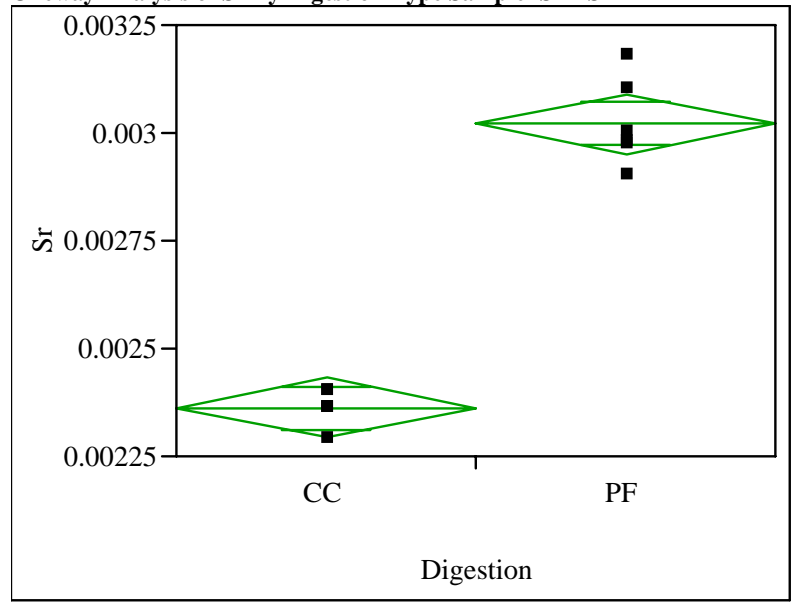

Oneway Anova

Summary of Fit

$\begin{array}{lr}\text { Rsquare } & 0.956825 \\ \text { Adj Rsquare } & 0.952508 \\ \text { Root Mean Square Error } & 7.679 \mathrm{e}-5 \\ \text { Mean of Response } & 0.002692 \\ \text { Observations (or Sum Wgts) } & 12\end{array}$

Observations (or Sum Wgts)

t Test

PF-CC

Assuming equal variances

Difference $\quad 0.000660$ t Ratio 14.8868 Std Err Dif $\quad 0.000044$ DF 10 Upper CL Dif 0.000759 Prob $>|t|<.0001$

Lower CL Dif 0.000561 Prob $>t \quad<.0001$

$\begin{array}{lll}\text { Confidence } & 0.95 \text { Prob }<\mathrm{t} \quad 1.0000\end{array}$

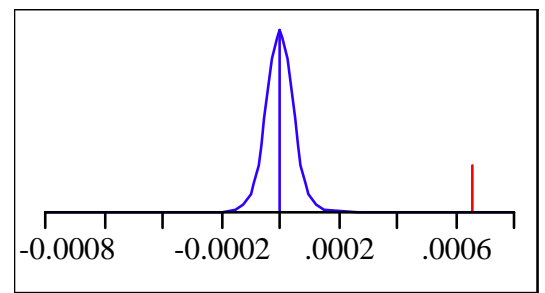

Analysis of Variance

Source DF Sum of Squares Mean Square F Ratio Prob $>$ F

Digestion $1 \quad 1.3068 \mathrm{e}-6 \quad 1.3068 \mathrm{e}-6 \quad 221.6167 \quad<.0001$

Error $\quad 10 \quad 5.89667 \mathrm{e}-8 \quad 5.8967 \mathrm{e}-9$

C. Total $11 \quad 1.36577 \mathrm{e}-6$

Means for Oneway Anova

Level Number Mean Std Error Lower 95\% Upper 95\%

$\begin{array}{llllll}\text { CC } & 6 & 0.002362 & 3.13 \mathrm{e}-5 & 0.00229 & 0.00243\end{array}$

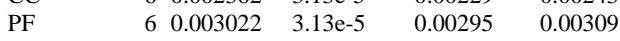

Std Error uses a pooled estimate of error variance 
WSRC-STI-2007-00515

Revision 0

Oneway Analysis of Ti By Digestion Type Sample=SB4 Sim

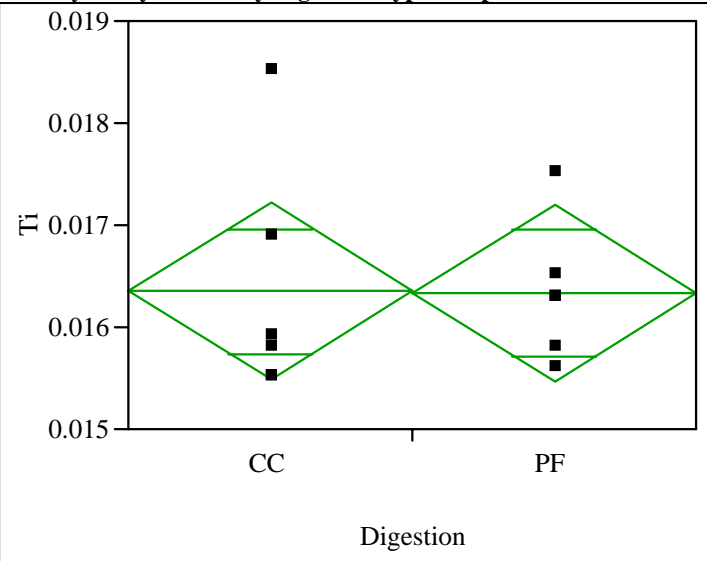

Oneway Anova

Summary of Fit

Rsquare $\quad 9.168 \mathrm{e}-5$

Adj Rsquare

$-0.0999$

Root Mean Square Error $\quad 0.000953$

Mean of Response

0.016342

Observations (or Sum Wgts) 12

t Test

PF-CC

Assuming equal variances

Difference $\quad-1.67 e-5$ t Ratio -0.03028

Std Err Dif $\quad 0.00055$ DF 10

Upper CL Dif 0.00121 Prob $>|t| \quad 0.9764$

Lower CL Dif -0.00124 Prob $>\mathrm{t} \quad 0.5118$

Confidence $\quad 0.95$ Prob $<\mathrm{t} \quad 0.4882$

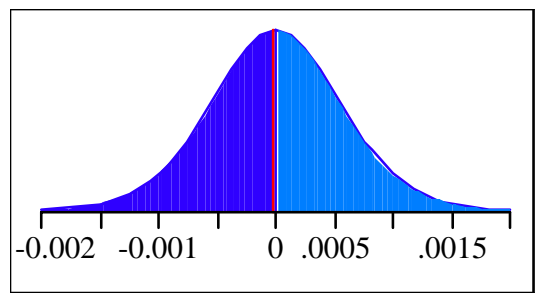

Analysis of Variance

Source DF Sum of Squares Mean Square F Ratio Prob $>$ F

$\begin{array}{llllll}\text { Digestion } & 1 & 8.3333 \mathrm{e}-10 & 8.333 \mathrm{e}-10 & 0.0009 & 0.9764\end{array}$

$\begin{array}{llll}\text { Error } \quad 10 & 9.08833 \mathrm{e}-6 & 9.0883 \mathrm{e}-7\end{array}$

C. Total $11 \quad 9.08917 \mathrm{e}-6$

Means for Oneway Anova

Level Number Mean Std Error Lower 95\% Upper 95\%

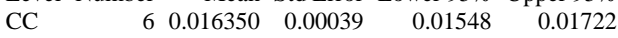

$\begin{array}{llllll}\mathrm{PF} & 6 & 0.016333 & 0.00039 & 0.01547 & 0.01720\end{array}$

Std Error uses a pooled estimate of error variance
Oneway Analysis of V By Digestion Type Sample=SB4 Sim

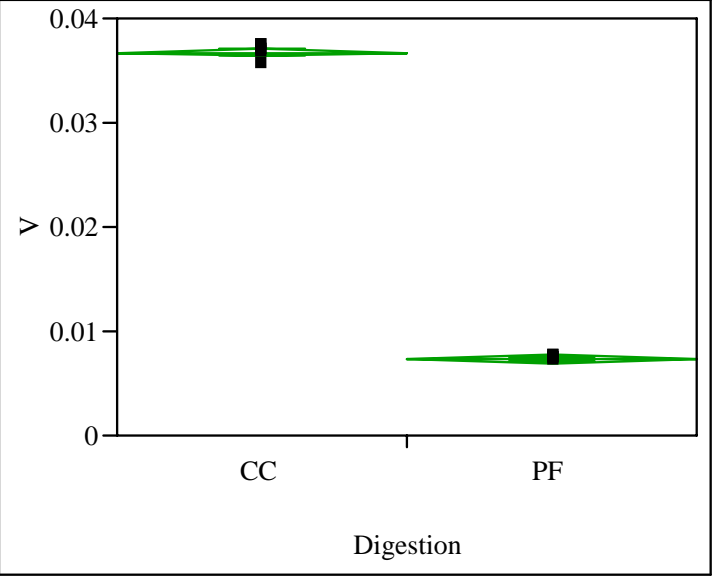

Oneway Anova

Summary of Fit

Rsquare

Adj Rsquare

Root Mean Square Error $\quad 0.000465$

Mean of Response $\quad 0.022067$

Observations (or Sum Wgts) 12

t Test

PF-CC

Assuming equal variances

Difference $\quad-0.02940$ t Ratio $\quad-109.434$

Std Err Dif $\quad 0.00027$ DF 10

Upper CL Dif -0.02880 Prob $>|\mathrm{t}| \quad 0.0000$

Lower CL Dif -0.03000 Prob $>t \quad 1.0000$

$\begin{array}{lr}\text { Confidence } & 0.95 \text { Prob }<\mathrm{t} \quad 0.0000\end{array}$

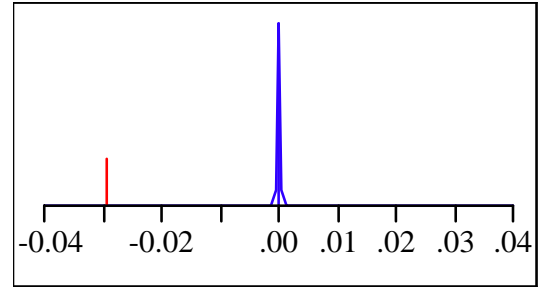

Analysis of Variance

Source DF Sum of Squares Mean Square F Ratio Prob $>$ F

$\begin{array}{llllll}\text { Digestion } & 1 & 0.00259308 & 0.002593 & 11975.80 & <.0001\end{array}$

$\begin{array}{llll}\text { Error } & 10 & 0.00000217 & 2.165 \mathrm{e}-7\end{array}$

C. Total $11 \quad 0.00259525$

Means for Oneway Anova

Level Number Mean Std Error Lower 95\% Upper 95\%

$\begin{array}{llllll}\text { CC } & 6 & 6.036767 & 0.00019 & 0.03634 & 0.03719\end{array}$

$\begin{array}{llllll}\mathrm{PF} & \quad 6 & 0.007367 & 0.00019 & 0.00694 & 0.00779\end{array}$

Std Error uses a pooled estimate of error variance 
WSRC-STI-2007-00515

Revision 0

Oneway Analysis of Zn By Digestion Type Sample=SB4 Sim

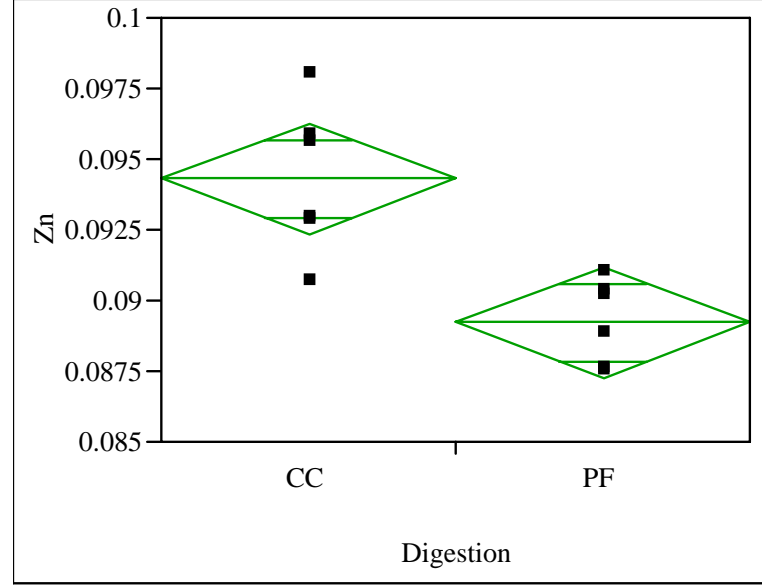

Oneway Anova

Summary of Fit

Rsquare

Adj Rsquare

0.626804

0.589485

Mean of Response $\quad 0.091767$

Observations (or Sum Wgts) 12

\section{t Test}

PF-CC

Assuming equal variances

Difference $\quad-0.00507$ t Ratio $\quad-4.09824$

Std Err Dif $\quad 0.00124$ DF 10

Upper CL Dif -0.00231 Prob $>|t| \quad 0.0022$

Lower CL Dif -0.00782 Prob $>$ t 0.9989

Confidence $\quad 0.95$ Prob $<\mathrm{t} \quad 0.0011$

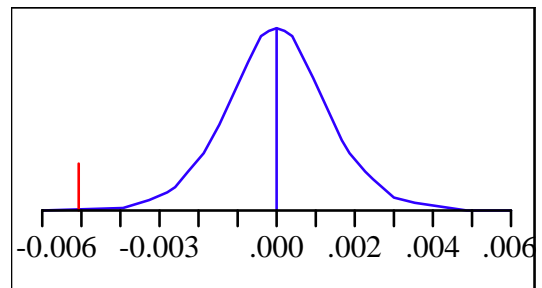

Analysis of Variance

Source DF Sum of Squares Mean Square F Ratio Prob $>$ F

$\begin{array}{lllllll}\text { Digestion } & 1 & 0.00007701 & 0.000077 & 16.7956 & 0.0022\end{array}$

$\begin{array}{llll}\text { Error } & 10 & 0.00004585 & 4.585 \mathrm{e}-6\end{array}$

C. Total $11 \quad 0.00012287$

Means for Oneway Anova

Level Number Mean Std Error Lower 95\% Upper 95\%

$\begin{array}{llllll}\text { CC } & 6 & 0.094300 & 0.00087 & 0.09235 & 0.09625\end{array}$

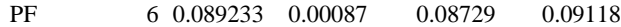

Std Error uses a pooled estimate of error variance 
WSRC-STI-2007-00515

Revision 0

Oneway Analysis of Zr By Digestion Type Sample=SB4 Sim

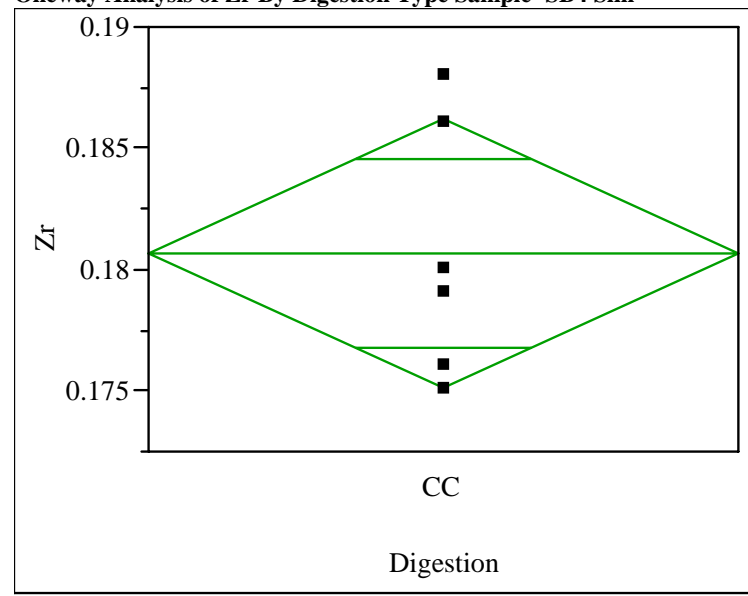

Missing Rows

6

Oneway Anova

Summary of Fit

Rsquare $\quad 1.11 \mathrm{e}-16$

Adj Rsquare $\quad 1.11 \mathrm{e}-16$

Root Mean Square Error $\quad 0.005279$

Mean of Response 0.180667

Observations (or Sum Wgts)

6

Analysis of Variance

Source DF Sum of Squares Mean Square F Ratio Prob $>$ F

Digestion $0 \quad 0.00000000$

$\begin{array}{llll}\text { Error } & 5 & 0.00013933 & 0.000028\end{array}$

C. Total 50.00013933

Means for Oneway Anova

Level Number Mean Std Error Lower 95\% Upper 95\%

$\begin{array}{llllrr}\text { CC } & 6 & 0.180667 & 0.00216 & 0.17513 & 0.18621\end{array}$

Std Error uses a pooled estimate of error variance 
WSRC-STI-2007-00515

Revision 0

\section{APPENDIX C}

JMP One-Way Analysis Plots of SB4 spiked with Boehmite Digested by DWPF CC + PF and PF 
WSRC-STI-2007-00515

Revision 0

Oneway Analysis of Measurement By Digestion Unit of Measure $=$ ug of element in sample, Element $=\mathrm{Ni}$

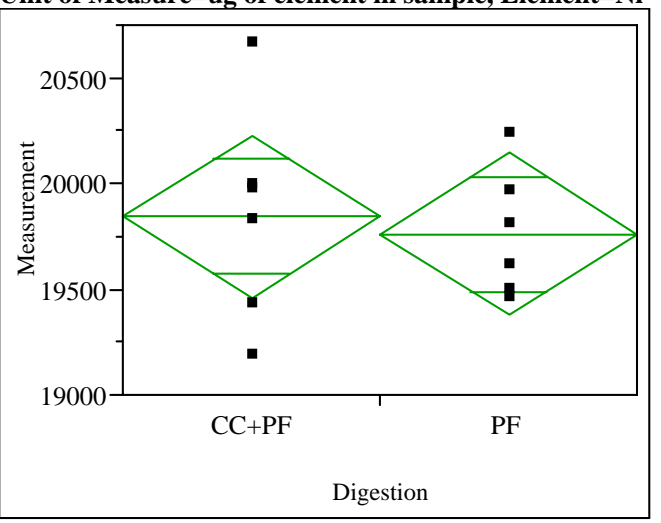

Oneway Anova

Summary of Fit

$\begin{array}{lr}\text { Rsquare } & 0.011927 \\ \text { Adj Rsquare } & -0.08688 \\ \text { Root Mean Square Error } & 421.3985 \\ \text { Mean of Response } & 19802.8 \\ \text { Observations (or Sum Wgts) } & 12\end{array}$

t Test

$\mathrm{PF}-\mathrm{CC}+\mathrm{PF}$

Assuming equal variances

Difference

Std Err Dif

Upper CL Dif

Lower CL Dif

Confidence
Oneway Analysis of Measurement By Digestion Unit of Measure $=$ ug of element in sample, Element $=\mathrm{Mg}$

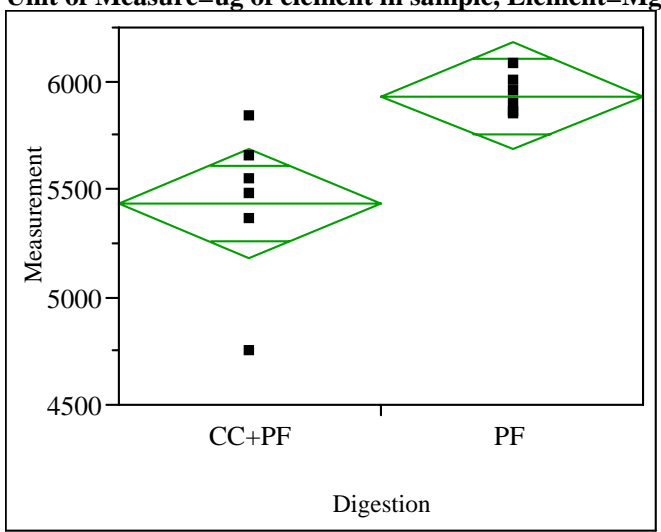

\section{Oneway Anova}

Summary of Fit

$\begin{array}{lr}\text { Rsquare } & 0.500855 \\ \text { Adj Rsquare } & 0.450941 \\ \text { Root Mean Square Error } & 273.1399 \\ \text { Mean of Response } & 5682.998 \\ \text { Observations (or Sum Wgts) } & 12\end{array}$

Test

PF-CC+PF

Assuming equal variances

Difference $\quad 499.537$ t Ratio 3.167691

Std Err Dif $\quad$ 157.697 DF $\quad 10$

Upper CL Dif 850.908 Prob $>|t| \quad 0.0100$

Lower CL Dif 148.165 Prob $>\mathrm{t} \quad 0.0050$

Confidence $\quad 0.95$ Prob $<\mathrm{t} \quad 0.9950$

Analysis of Variance

Source DF Sum of Squares Mean Square F Ratio Prob $>$ F $\begin{array}{llllll}\text { Digestion } & 1 & 748610.6 & 748611 & 10.0343 & 0.0100\end{array}$

$\begin{array}{llll}\text { Error } & 10 & 746054.0 & 74605\end{array}$

C. Total $11 \quad 1494664.7$

Means for Oneway Anova

Level Number Mean Std Error Lower 95\% Upper 95\%

$\begin{array}{llllll}\mathrm{CC}+\mathrm{PF} & 6 & 5433.23 & 111.51 & 5184.8 & 5681.7\end{array}$

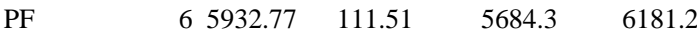

Std Error uses a pooled estimate of error variance

t Test

$\mathrm{PF}-\mathrm{CC}+\mathrm{PF}$

Assuming unequal variances

$\begin{array}{lrlr}\text { Difference } & 499.537 \text { t Ratio } & 3.167691 \\ \text { Std Err Dif } & 157.697 \text { DF } & 5.582569 \\ \text { Upper CL Dif } & \text { 892.511 } \text { Prob }>|t| & 0.0214 \\ \text { Lower CL Dif } & 106.562 \text { Prob }>\text { t } & 0.0107 \\ \text { Confidence } & 0.95 \text { Prob }<\text { t } & 0.9893\end{array}$


WSRC-STI-2007-00515

Oneway Analysis of Measurement By Digestion

Unit of Measure=ug of element in sample, Element $=F$

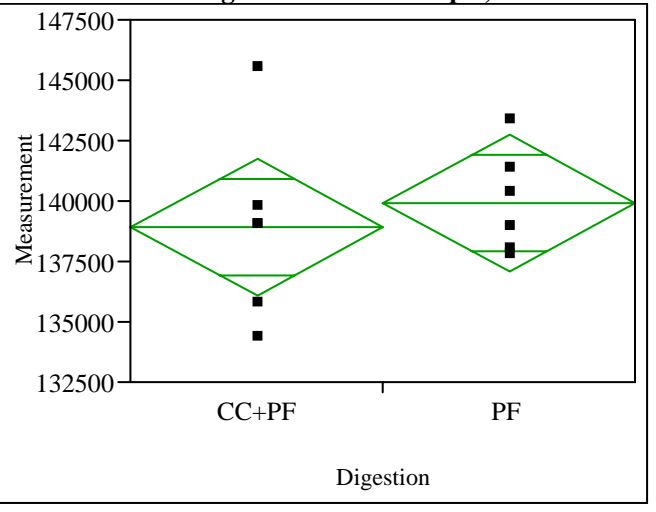

Oneway Anova

Summary of Fit

Rsquare

0.033043

Adj Rsquare

$-0.06365$

Root Mean Square Error

3125.612

Mean of Response

139417.6

Observations (or Sum Wgts)

12

t Test

PF-CC+PF

Assuming equal variances

Difference $\quad 1054.9$ t Ratio 0.584572

Std Err Dif 1804.6 DF 10

Upper CL Dif 5075.7 Prob $>|t| \quad 0.5718$

Lower CL Dif -2965.9 Prob $>$ t 0.2859

Confidence $\quad 0.95$ Prob $<\mathrm{t} \quad 0.7141$

Analysis of Variance

Source DF Sum of Squares Mean Square F Ratio Prob $>$ F

$\begin{array}{llllll}\text { Digestion } & 1 & 3338463 & 3338463 & 0.3417 & 0.5718\end{array}$

$\begin{array}{llll}\text { Error } & 10 & 97694502 & 9769450\end{array}$

C. Total $11 \quad 101032965$

Means for Oneway Anova

Level Number Mean Std Error Lower 95\% Upper 95\%

$\begin{array}{llllll}\mathrm{CC}+\mathrm{PF} & 6 & 138890 & 1276.0 & 136047 & 141733\end{array}$

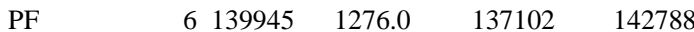

Std Error uses a pooled estimate of error variance

t Test

PF-CC+PF

Assuming unequal variances

Difference $\quad 1054.9$ t Ratio $\quad 0.584572$

Std Err Dif $\quad$ 1804.6 DF $\quad 7.802025$

Upper CL Dif 5234.7 Prob $>|t| \quad 0.5753$

Lower CL Dif -3124.9 Prob $>\mathrm{t} \quad 0.2877$

Confidence $\quad 0.95$ Prob $<\mathrm{t} \quad 0.7123$
Oneway Analysis of Measurement By Digestion

Unit of Measure $=$ ug of element in sample, Element $=\mathrm{Cr}$

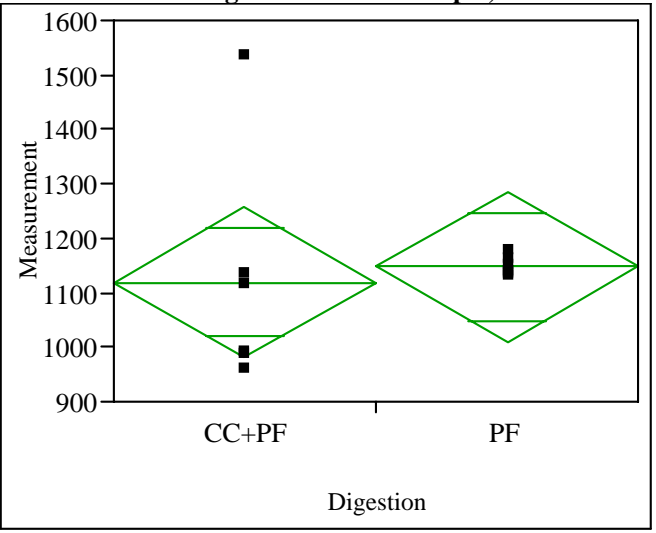

Oneway Anova

Summary of Fit

$\begin{array}{lr}\text { Rsquare } & 0.009875 \\ \text { Adj Rsquare } & -0.08914 \\ \text { Root Mean Square Error } & 152.9819 \\ \text { Mean of Response } & 1133.153 \\ \text { Observations (or Sum Wgts) } & 12\end{array}$

t Test

PF-CC+PF

Assuming equal variances

$\begin{array}{lrlr}\text { Difference } & 27.89 \text { t Ratio } & 0.315808 \\ \text { Std Err Dif } & 88.32 \text { DF } & 10 \\ \text { Upper CL Dif } & 224.69 \text { Prob }>|t| & 0.7586 \\ \text { Lower CL Dif } & -168.90 \text { Prob }>\text { t } & 0.3793 \\ \text { Confidence } & 0.95 \text { Prob }<\mathrm{t} & 0.6207\end{array}$

Analysis of Variance

Source DF Sum of Squares Mean Square F Ratio Prob > F

$\begin{array}{llllll}\text { Digestion } & 1 & 2334.14 & 2334.1 & 0.0997 & 0.7586\end{array}$

$\begin{array}{llll}\text { Error } & 10 & 234034.71 & 23403.5\end{array}$

C. Total $11 \quad 236368.85$

Means for Oneway Anova

$\begin{array}{lrrr}\text { Level } & \text { Number } & \text { Mean } & \text { Std Error } \\ \text { CC+PF } & 6 & 1119.21 & 62.455 \\ \text { PF } & 6 & 1147.10 & 62.455\end{array}$

Std Error uses a pooled estimate of error variance

t Test

PF-CC+PF

Assuming unequal variances

$\begin{array}{lrlr}\text { Difference } & 27.89 \text { t Ratio } & 0.315808 \\ \text { Std Err Dif } & 88.32 \text { DF } & 5.066365 \\ \text { Upper CL Dif } & 254.05 \text { Prob }>|t| & 0.7647 \\ \text { Lower CL Dif } & -198.26 \text { Prob }>\text { t } & 0.3824 \\ \text { Confidence } & 0.95 \text { Prob }<\mathrm{t} & 0.6176\end{array}$ 
WSRC-STI-2007-00515

Oneway Analysis of Measurement By Digestion

Unit of Measure=ug of element in sample, Element=Ca

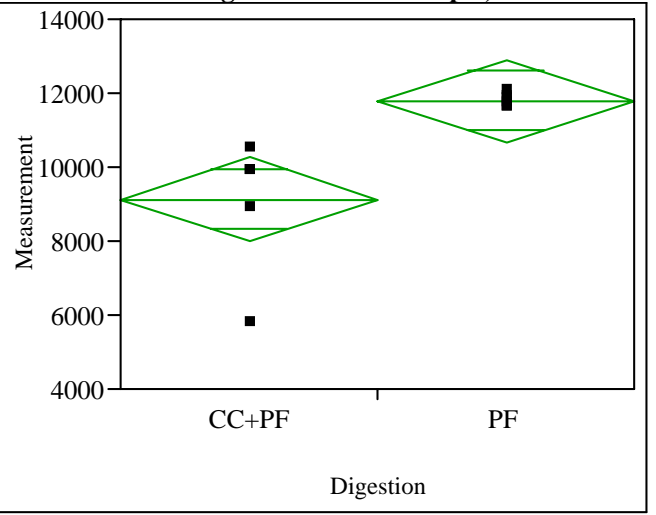

\section{Oneway Anova}

Summary of Fit

$\begin{array}{lr}\text { Rsquare } & 0.581804 \\ \text { Adj Rsquare } & 0.539984 \\ \text { Root Mean Square Error } & 1232.175 \\ \text { Mean of Response } & 10465.36 \\ \text { Observations (or Sum Wgts) } & 12\end{array}$

t Test

$\mathrm{PF}-\mathrm{CC}+\mathrm{PF}$

Assuming equal variances

$\begin{array}{lrr}\text { Difference } & 2653.45 \text { t Ratio } & 3.729909 \\ \text { Std Err Dif } & 711.40 \text { DF } & 10 \\ \text { Upper CL Dif } & 4238.54 \text { Prob }>|t| & 0.0039 \\ \text { Lower CL Dif } & 1068.35 \text { Prob }>\text { t } & 0.0020 \\ \text { Confidence } & 0.95 \text { Prob }<\mathrm{t} & 0.9980\end{array}$

Analysis of Variance

Source DF Sum of Squares Mean Square F Ratio Prob $>$ F

$\begin{array}{llllll}\text { Digestion } & 1 & 21122311 & 21122311 & 13.9122 & 0.0039\end{array}$

$\begin{array}{llll}\text { Error } & 10 & 15182558 & 1518255.8\end{array}$

C. Total $11 \quad 36304869$

Means for Oneway Anova

Level Number Mean Std Error Lower 95\% Upper 95\%

$\begin{array}{llllll}\mathrm{CC}+\mathrm{PF} & 6 & 9138.6 & 503.03 & 8018 & 10259\end{array}$

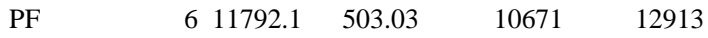

Std Error uses a pooled estimate of error variance

t Test

PF-CC+PF

Assuming unequal variances

Difference $\quad 2653.45$ t Ratio 3.729909

Std Err Dif $\quad 711.40$ DF $\quad 5.108314$

Upper CL Dif 4470.55 Prob $>|t| \quad 0.0131$

Lower CL Dif 836.34 Prob $>t \quad 0.0065$

Confidence $\quad 0.95$ Prob $<\mathrm{t} \quad 0.9935$
Oneway Analysis of Measurement By Digestion Unit of Measure $=$ ug of element in sample, Element $=B$

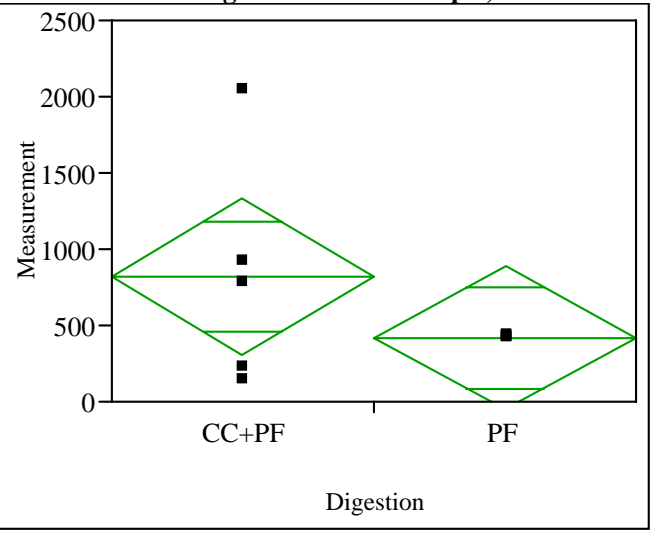

Oneway Anova

Summary of Fit

$\begin{array}{lr}\text { Rsquare } & 0.157705 \\ \text { Adj Rsquare } & 0.064116 \\ \text { Root Mean Square Error } & 509.0479 \\ \text { Mean of Response } & 602.4793 \\ \text { Observations (or Sum Wgts) } & 11\end{array}$

t Test

$\mathrm{PF}-\mathrm{CC}+\mathrm{PF}$

Assuming equal variances

$\begin{array}{lrlr}\text { Difference } & -400.1 \text { t Ratio } & -1.29811 \\ \text { Std Err Dif } & 308.2 \text { DF } & 9 \\ \text { Upper CL Dif } & 297.2 \text { Prob }>|t| & 0.2265 \\ \text { Lower CL Dif } & -1097.4 \text { Prob }>\text { t } & 0.8867 \\ \text { Confidence } & 0.95 \text { Prob }<\mathrm{t} & 0.1133\end{array}$

Analysis of Variance

Source DF Sum of Squares Mean Square F Ratio Prob > F $\begin{array}{llllll}\text { Digestion } & 1 & 436656.9 & 436657 & 1.6851 & 0.2265\end{array}$

$\begin{array}{llll}\text { Error } & 9 & 2332168.1 & 259130\end{array}$

C. Total $10 \quad 2768825.0$

Means for Oneway Anova

Level Number Mean Std Error Lower 95\% Upper 95\%

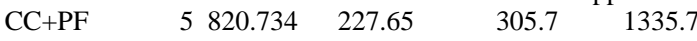

$\begin{array}{llllll}\mathrm{PF} & 6 & 420.600 & 207.82 & -49.5 & 890.7\end{array}$

Std Error uses a pooled estimate of error variance

t Test

PF-CC+PF

Assuming unequal variances

$\begin{array}{lrlr}\text { Difference } & -400.1 \text { t Ratio } & -1.17178 \\ \text { Std Err Dif } & 341.5 \text { DF } & 4.000476 \\ \text { Upper CL Dif } & 547.9 \text { Prob }>|t| & 0.3063 \\ \text { Lower CL Dif } & -1348.2 \text { Prob }>\text { t } & 0.8468 \\ \text { Confidence } & 0.95 \text { Prob }<\mathrm{t} & 0.1532\end{array}$ 
WSRC-STI-2007-00515

Oneway Analysis of Measurement By Digestion

Unit of Measure $=$ ug of element in sample, Element $=A l$

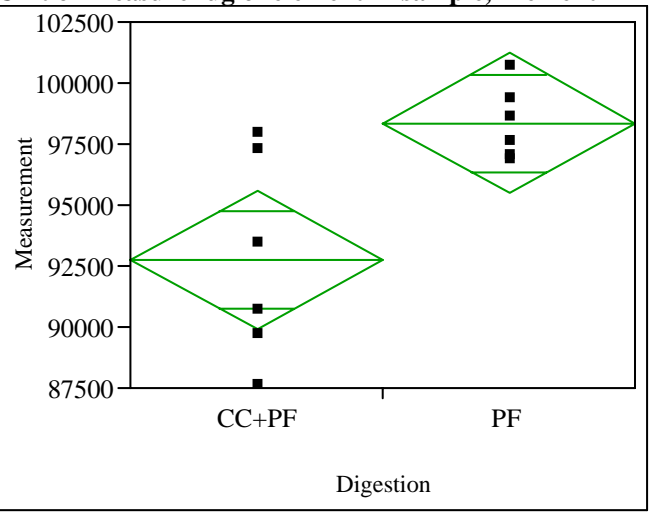

Oneway Anova

Summary of Fit

$\begin{array}{lr}\text { Rsquare } & 0.486512 \\ \text { Adj Rsquare } & 0.435164 \\ \text { Root Mean Square Error } & 3151.754 \\ \text { Mean of Response } & 95543.33 \\ \text { Observations (or Sum Wgts) } & 12\end{array}$

t Test

$\mathrm{PF}-\mathrm{CC}+\mathrm{PF}$

Assuming equal variances

Difference $\quad 5601.11$ t Ratio $\quad 3.078095$

Std Err Dif 1819.67 DF 10

Upper CL Dif 9655.57 Prob $>|t| \quad 0.0117$

Lower CL Dif 1546.64 Prob $>\mathrm{t} \quad 0.0058$

Confidence $\quad 0.95$ Prob $<\mathrm{t} \quad 0.9942$

Analysis of Variance

Source DF Sum of Squares Mean Square F Ratio Prob > F

$\begin{array}{llllll}\text { Digestion } & 1 & 94117132 & 94117132 & 9.4747 & 0.0117\end{array}$

$\begin{array}{llll}\text { Error } & 10 & 99335538 & 9933553.8\end{array}$

C. Total $11 \quad 193452670$

Means for Oneway Anova

Level Number Mean Std Error Lower 95\% Upper 95\%

$\begin{array}{llllll}\mathrm{CC}+\mathrm{PF} & 6 & 92742.8 & 1286.7 & 89876 & 95610\end{array}$

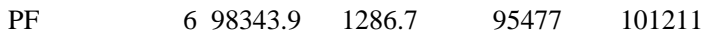

Std Error uses a pooled estimate of error variance

t Test

$\mathrm{PF}-\mathrm{CC}+\mathrm{PF}$

Assuming unequal variances

$\begin{array}{lrlr}\text { Difference } & 5601.1 \text { t Ratio } & 3.078095 \\ \text { Std Err Dif } & 1819.7 \text { DF } & 6.265084 \\ \text { Upper CL Dif } & 10008.4 \text { Prob }>|t| & 0.0205 \\ \text { Lower CL Dif } & 1193.8 \text { Prob }>\text { t } & 0.0103 \\ \text { Confidence } & 0.95 \text { Prob }<\mathrm{t} & 0.9897\end{array}$

Oneway Analysis of Measurement By Digestion

Unit of Measure $=$ ug of element in sample, Element=Ba

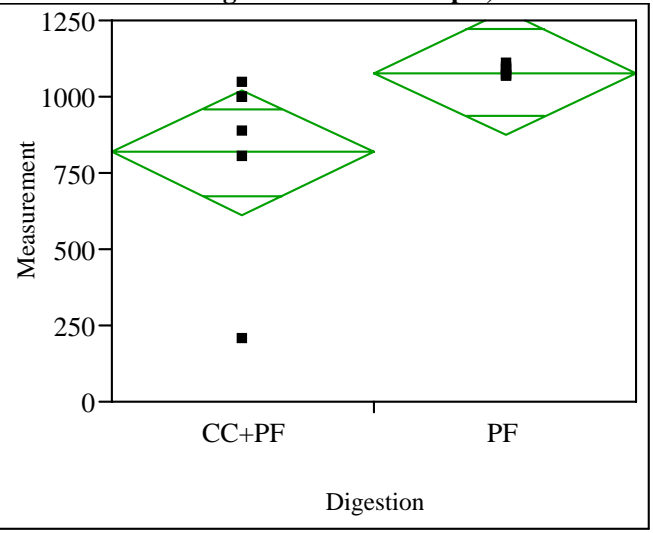

Oneway Anova

Summary of Fit

$\begin{array}{lr}\text { Rsquare } & 0.291622 \\ \text { Adj Rsquare } & 0.220785 \\ \text { Root Mean Square Error } & 222.8193 \\ \text { Mean of Response } & 947.7578 \\ \text { Observations (or Sum Wgts) } & 12\end{array}$

t Test

PF-CC+PF

Assuming equal variances

Difference 261.02 t Ratio $\quad 2.028981$

Std Err Dif 128.64 DF 10

Upper CL Dif 547.66 Prob $>|t| \quad 0.0699$

Lower CL Dif -25.62 Prob $>\mathrm{t} \quad 0.0350$

Confidence $\quad 0.95$ Prob $<\mathrm{t} \quad 0.9650$

Analysis of Variance

Source DF Sum of Squares Mean Square F Ratio Prob > F

$\begin{array}{llllll}\text { Digestion } & 1 & 204390.90 & 204391 & 4.1168 & 0.0699\end{array}$

$\begin{array}{llll}\text { Error } & 10 & 496484.53 & 49648\end{array}$

C. Total $11 \quad 700875.43$

Means for Oneway Anova

Level Number Mean Std Error Lower 95\% Upper 95\%

$\begin{array}{llllll}\mathrm{CC}+\mathrm{PF} & 6 & 817.25 & 90.966 & 614.56 & 1019.9\end{array}$

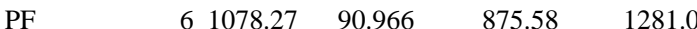

Std Error uses a pooled estimate of error variance

t Test

PF-CC+PF

Assuming unequal variances

$\begin{array}{lrr}\text { Difference } & 261.02 \text { t Ratio } & 2.028981 \\ \text { Std Err Dif } & 128.64 \text { DF } & 5.027493 \\ \text { Upper CL Dif } & 591.17 \text { Prob }>|t| & 0.0979 \\ \text { Lower CL Dif } & -69.13 \text { Prob }>\text { t } & 0.0490 \\ \text { Confidence } & 0.95 \text { Prob }<\text { t } & 0.9510\end{array}$ 
WSRC-STI-2007-00515

Oneway Analysis of Measurement By Digestion

Unit of Measure $=u g$ of element in sample, Element $=\mathrm{Co}_{0}$

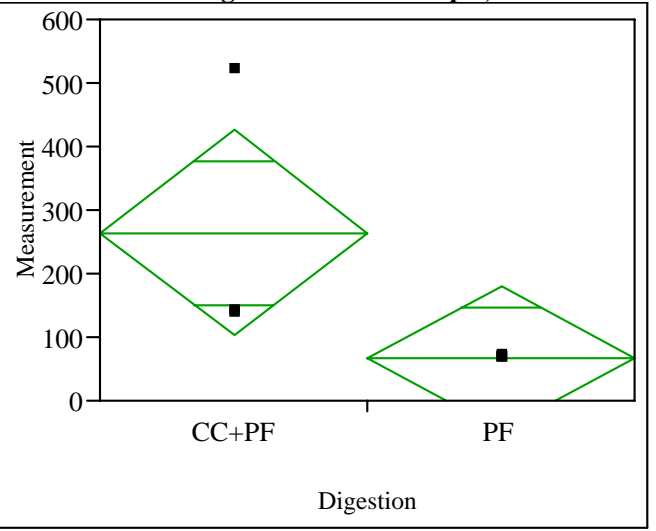

Oneway Anova

Summary of Fit

$\begin{array}{lr}\text { Rsquare } & 0.447646 \\ \text { Adj Rsquare } & 0.368738 \\ \text { Root Mean Square Error } & 117.5397 \\ \text { Mean of Response } & 132.7867 \\ \text { Observations (or Sum Wgts) } & 9\end{array}$

t Test

PF-CC+PF

Assuming equal variances

$\begin{array}{lrr}\text { Difference } & -197.96 \text { t Ratio } & -2.38181 \\ \text { Std Err Dif } & 83.11 \text { DF } & 7 \\ \text { Upper CL Dif } & -1.43 \text { Prob }>|t| & 0.0488 \\ \text { Lower CL Dif } & -394.49 \text { Prob }>t & 0.9756 \\ \text { Confidence } & 0.95 \text { Prob }<\mathrm{t} & 0.0244\end{array}$

Analysis of Variance

Source DF Sum of Squares Mean Square F Ratio Prob > F

$\begin{array}{llllll}\text { Digestion } & 1 & 78376.32 & 78376.3 & 5.6730 & 0.0488\end{array}$

$\begin{array}{llrr}\text { Error } & 7 & 96709.13 & 13815.6\end{array}$

$\begin{array}{llr}\text { C. Total } & 8 & 175085.45\end{array}$

Means for Oneway Anova

Level Number Mean Std Error Lower 95\% Upper 95\%

\begin{tabular}{llllll}
$\mathrm{CC}+\mathrm{PF}$ & 3 & 264.760 & 67.862 & 104.3 & 425.23 \\
\hline
\end{tabular}

$\begin{array}{llllll}\mathrm{PF} & 6 & 66.800 & 47.985 & -46.7 & 180.27\end{array}$

Std Error uses a pooled estimate of error variance

t Test

$\mathrm{PF}-\mathrm{CC}+\mathrm{PF}$

Assuming unequal variances

$\begin{array}{lrlr}\text { Difference } & -197.96 \text { t Ratio } & -1.5593 \\ \text { Std Err Dif } & 126.95 \text { DF } & 2.000044 \\ \text { Upper CL Dif } & 348.27 \text { Prob }>|t| & 0.2593 \\ \text { Lower CL Dif } & -744.19 \text { Prob }>\text { t } & 0.8704 \\ \text { Confidence } & 0.95 \text { Prob }<\text { t } & 0.1296\end{array}$

Oneway Analysis of Measurement By Digestion

Revision 0

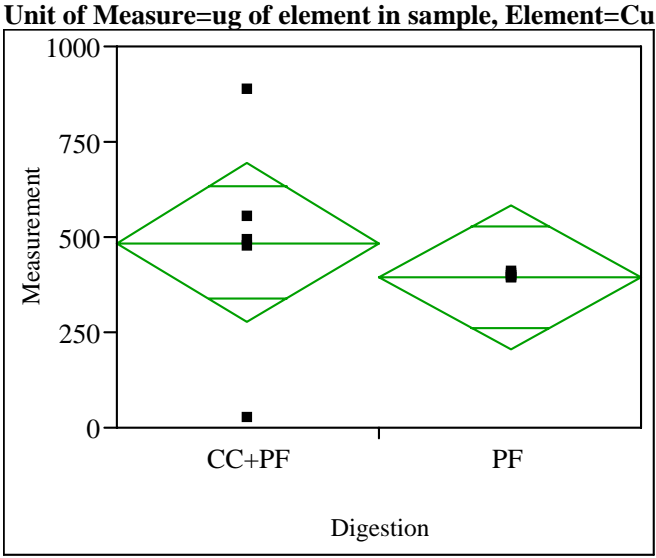

Oneway Anova

Summary of Fit

$\begin{array}{lr}\text { Rsquare } & 0.052882 \\ \text { Adj Rsquare } & -0.05235 \\ \text { Root Mean Square Error } & 205.8122 \\ \text { Mean of Response } & 435.34 \\ \text { Observations (or Sum Wgts) } & 11\end{array}$

t Test

PF-CC+PF

Assuming equal variances

$\begin{array}{lrrr}\text { Difference } & -88.34 \text { t Ratio } & -0.70888 \\ \text { Std Err Dif } & 124.63 \text { DF } & 9 \\ \text { Upper CL Dif } & 193.58 \text { Prob }>|t| & 0.4963 \\ \text { Lower CL Dif } & -370.27 \text { Prob }>\text { t } & 0.7518 \\ \text { Confidence } & 0.95 \text { Prob }<t & 0.2482\end{array}$

Analysis of Variance

Source DF Sum of Squares Mean Square F Ratio Prob > F $\begin{array}{llllll}\text { Digestion } & 1 & 21285.76 & 21285.8 & 0.5025 & 0.4963\end{array}$ $\begin{array}{llll}\text { Error } & 9 & 381227.78 & 42358.6\end{array}$

C. Total $10 \quad 402513.55$

Means for Oneway Anova

Level Number Mean Std Error Lower 95\% Upper 95\% $\begin{array}{lllllr}\mathrm{CC}+\mathrm{PF} & 5 & 483.528 & 92.042 & 275.31 & 691.74\end{array}$

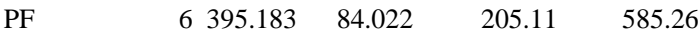

Std Error uses a pooled estimate of error variance

t Test

PF-CC+PF

Assuming unequal variances

$\begin{array}{lrr}\text { Difference } & -88.34 \text { t Ratio } & -0.63994 \\ \text { Std Err Dif } & 138.05 \text { DF } & 4.002573 \\ \text { Upper CL Dif } & 294.85 \text { Prob }>|t| & 0.5570 \\ \text { Lower CL Dif } & -471.54 \text { Prob }>\text { t } & 0.7215 \\ \text { Confidence } & 0.95 \text { Prob }<\mathrm{t} & 0.2785\end{array}$


WSRC-STI-2007-00515

Oneway Analysis of Measurement By Digestion

Unit of Measure $=$ ug of element in sample, Element $=K$

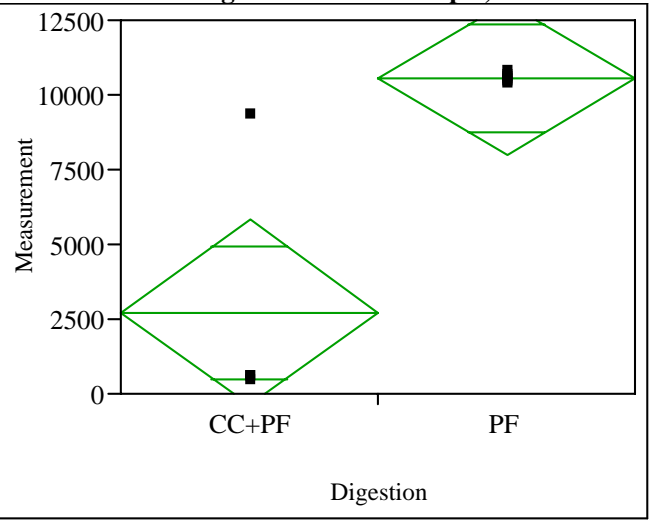

Oneway Anova

Summary of Fit

Rsquare $\quad 0.716224$

Adj Rsquare $\quad 0.680752$

Root Mean Square Error $\quad 2696.596$

Mean of Response $\quad 7404.734$

Observations (or Sum Wgts) 10

t Test

PF-CC+PF

Assuming equal variances

$\begin{array}{lrlr}\text { Difference } & 7821.5 \text { t Ratio } & 4.493472 \\ \text { Std Err Dif } & 1740.6 \text { DF } & 8 \\ \text { Upper CL Dif } & 11835.5 \text { Prob }>|t| & 0.0020 \\ \text { Lower CL Dif } & 3807.6 \text { Prob }>\text { t } & 0.0010 \\ \text { Confidence } & 0.95 \text { Prob }<\mathrm{t} & 0.9990\end{array}$

Analysis of Variance

Source DF Sum of Squares Mean Square F Ratio Prob > F

$\begin{array}{lllllll}\text { Digestion } & 1 & 146823571 & 146823571 & 20.1913 & 0.0020\end{array}$

$\begin{array}{llll}\text { Error } & 8 & 58173026 & 7271628.3\end{array}$

C. Total 9204996597

Means for Oneway Anova

Level Number Mean Std Error Lower 95\% Upper 95\%

$\begin{array}{llllll}\mathrm{CC}+\mathrm{PF} & 4 & 2711.8 & 1348.3 & -397 & 5821\end{array}$

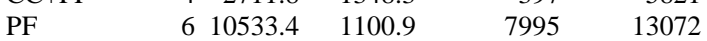

Std Error uses a pooled estimate of error variance

t Test

PF-CC+PF

Assuming unequal variances

$\begin{array}{lrlr}\text { Difference } & 7821.5 \text { t Ratio } & 3.554783 \\ \text { Std Err Dif } & 2200.3 \text { DF } & 3.00537 \\ \text { Upper CL Dif } & 14816.8 \text { Prob }>|t| & 0.0379 \\ \text { Lower CL Dif } & 826.3 \text { Prob }>\text { t } & 0.0189 \\ \text { Confidence } & 0.95 \text { Prob }<\mathrm{t} & 0.9811\end{array}$

Oneway Analysis of Measurement By Digestion Unit of Measure=ug of element in sample, Element $=M n$

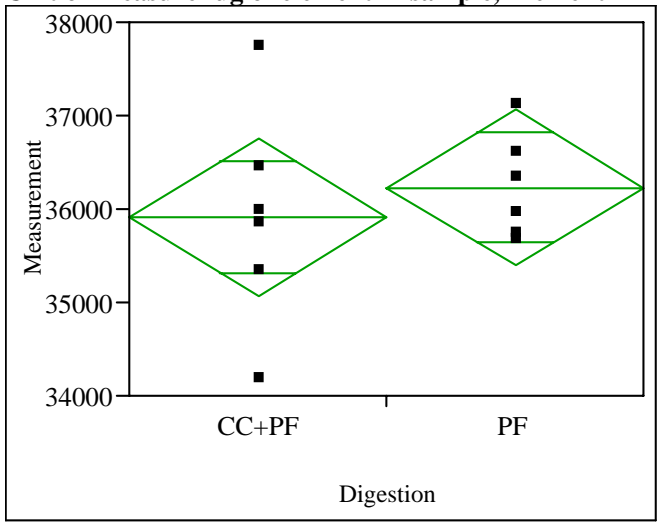

Oneway Anova

Summary of Fit

$\begin{array}{lr}\text { Rsquare } & 0.033856 \\ \text { Adj Rsquare } & -0.06276 \\ \text { Root Mean Square Error } & 925.4271 \\ \text { Mean of Response } & 36074.61 \\ \text { Observations (or Sum Wgts) } & 12\end{array}$

t Test

$\mathrm{PF}-\mathrm{CC}+\mathrm{PF}$

Assuming equal variances

$\begin{array}{lrlr}\text { Difference } & 316.3 \text { t Ratio } & 0.591966 \\ \text { Std Err Dif } & 534.3 \text { DF } & 10 \\ \text { Upper CL Dif } & 1506.8 \text { Prob }>|t| & 0.5670 \\ \text { Lower CL Dif } & -874.2 \text { Prob }>\text { t } & 0.2835 \\ \text { Confidence } & 0.95 \text { Prob }<\mathrm{t} & 0.7165\end{array}$

Analysis of Variance

Source DF Sum of Squares Mean Square F Ratio Prob > F

$\begin{array}{llllll}\text { Digestion } & 1 & 300108.6 & 300109 & 0.3504 & 0.5670\end{array}$

$\begin{array}{llll}\text { Error } & 10 & 8564153.3 & 856415\end{array}$

C. Total $11 \quad 8864261.9$

Means for Oneway Anova

Level Number Mean Std Error Lower 95\% Upper 95\%

$\begin{array}{llllll}\mathrm{CC}+\mathrm{PF} & 6 & 35916.5 & 377.80 & 35075 & 36758\end{array}$

$\begin{array}{llllll}\mathrm{PF} & 6 & 36232.8 & 377.80 & 35391 & 37075\end{array}$

Std Error uses a pooled estimate of error variance

t Test

$\mathrm{PF}-\mathrm{CC}+\mathrm{PF}$

Assuming unequal variances

$\begin{array}{lrlr}\text { Difference } & 316.3 \text { t Ratio } & 0.591966 \\ \text { Std Err Dif } & 534.3 \text { DF } & 7.086401 \\ \text { Upper CL Dif } & 1576.6 \text { Prob }>|t| & 0.5723 \\ \text { Lower CL Dif } & -944.0 \text { Prob }>\text { t } & 0.2861 \\ \text { Confidence } & 0.95 \text { Prob }<\text { t } & 0.7139\end{array}$


WSRC-STI-2007-00515

Oneway Analysis of Measurement By Digestion

Unit of Measure $=$ ug of element in sample, Element $=\mathbf{P b}$

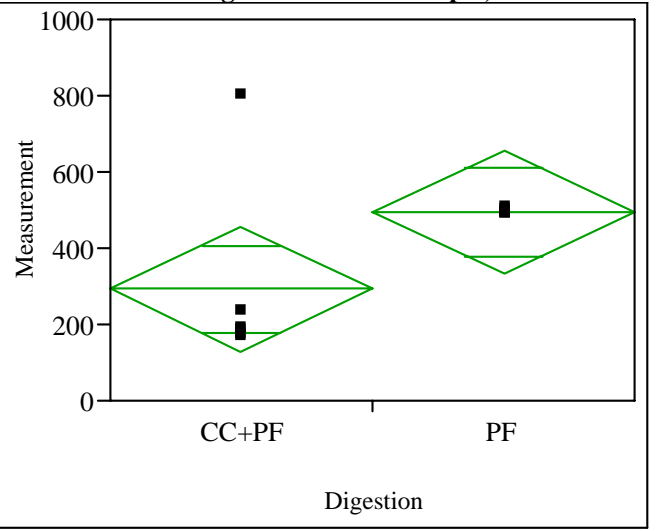

Oneway Anova

Summary of Fit

$\begin{array}{lr}\text { Rsquare } & 0.281053 \\ \text { Adj Rsquare } & 0.209158 \\ \text { Root Mean Square Error } & 177.6512 \\ \text { Mean of Response } & 393.0702 \\ \text { Observations (or Sum Wgts) } & 12\end{array}$

t Test

PF-CC+PF

Assuming equal variances

Difference $\quad 202.79$ t Ratio $\quad 1.977177$

Std Err Dif 102.57 DF 10

Upper CL Dif 431.33 Prob $>|t| \quad 0.0762$

Lower CL Dif -25.74 Prob $>\mathrm{t} \quad 0.0381$

Confidence $\quad 0.95$ Prob $<\mathrm{t} \quad 0.9619$

\section{Analysis of Variance}

Source DF Sum of Squares Mean Square F Ratio Prob > F

$\begin{array}{llllll}\text { Digestion } & 1 & 123375.00 & 123375 & 3.9092 & 0.0762\end{array}$

$\begin{array}{llll}\text { Error } & 10 & 315599.31 & 31560\end{array}$

C. Total $11 \quad 438974.32$

Means for Oneway Anova

Level Number Mean Std Error Lower 95\% Upper 95\%

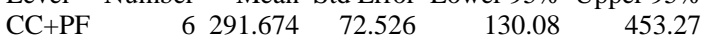

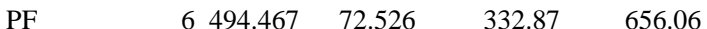

Std Error uses a pooled estimate of error variance

t Test

$\mathrm{PF}-\mathrm{CC}+\mathrm{PF}$

Assuming unequal variances

$\begin{array}{lrlr}\text { Difference } & 202.79 \text { t Ratio } & 1.977177 \\ \text { Std Err Dif } & 102.57 \text { DF } & 5.009035 \\ \text { Upper CL Dif } & 466.31 \text { Prob }>|t| & 0.1049 \\ \text { Lower CL Dif } & -60.72 \text { Prob }>\text { t } & 0.0524 \\ \text { Confidence } & 0.95 \text { Prob }<\text { t } & 0.9476\end{array}$

Oneway Analysis of Measurement By Digestion

Unit of Measure=ug of element in sample, Element=Si

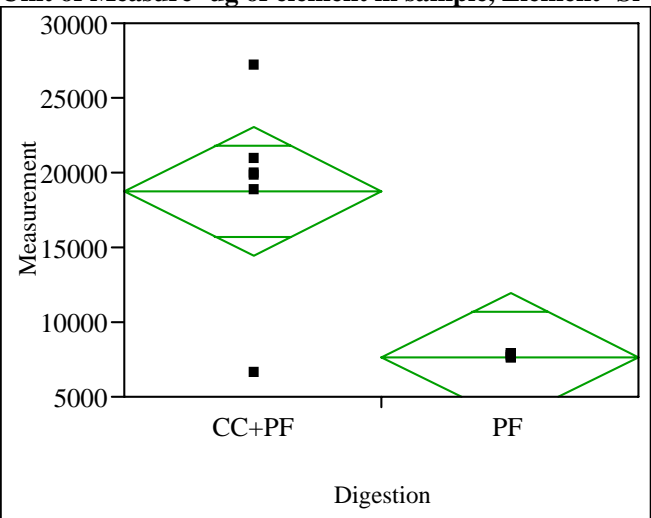

Oneway Anova

Summary of Fit

$\begin{array}{lr}\text { Rsquare } & 0.622461 \\ \text { Adj Rsquare } & 0.584707 \\ \text { Root Mean Square Error } & 4740.289 \\ \text { Mean of Response } & 13218.9 \\ \text { Observations (or Sum Wgts) } & 12\end{array}$

t Test

$\mathrm{PF}-\mathrm{CC}+\mathrm{PF}$

Assuming equal variances

$\begin{array}{lrr}\text { Difference } & -11113 \text { t Ratio } & -4.06046 \\ \text { Std Err Dif } & 2737 \text { DF } & 10 \\ \text { Upper CL Dif } & -5015 \text { Prob }>|t| & 0.0023 \\ \text { Lower CL Dif } & -17211 \text { Prob }>\text { t } & 0.9989 \\ \text { Confidence } & 0.95 \text { Prob }<\text { t } & 0.0011\end{array}$

Analysis of Variance

Source DF Sum of Squares Mean Square F Ratio Prob > F

$\begin{array}{lllllll}\text { Digestion } & 1 & 370476415 & 370476415 & 16.4874 & 0.0023\end{array}$

$\begin{array}{llll}\text { Error } & 10 & 224703395 & 22470340\end{array}$

C. Total $11 \quad 595179810$

Means for Oneway Anova

Level Number Mean Std Error Lower 95\% Upper 95\%

$\begin{array}{llllll}\mathrm{CC}+\mathrm{PF} & 6 & 18775.3 & 1935.2 & 14463 & 23087\end{array}$

$\begin{array}{lrrrrr}\mathrm{PF} & 6 & 7662.6 & 1935.2 & 3351 & 11974\end{array}$

Std Error uses a pooled estimate of error variance

t Test

$\mathrm{PF}-\mathrm{CC}+\mathrm{PF}$

Assuming unequal variances

$\begin{array}{lrr}\text { Difference } & -11113 \text { t Ratio } & -4.06046 \\ \text { Std Err Dif } & 2737 \text { DF } & 5.003058 \\ \text { Upper CL Dif } & -4079 \text { Prob }>|t| & 0.0097 \\ \text { Lower CL Dif } & -18147 \text { Prob }>\text { t } & 0.9951 \\ \text { Confidence } & 0.95 \text { Prob }<\text { t } & 0.0049\end{array}$


WSRC-STI-2007-00515

Revision 0

Oneway Analysis of Measurement By Digestion

Unit of Measure=ug of element in sample, Element $=\mathbf{Z n}$

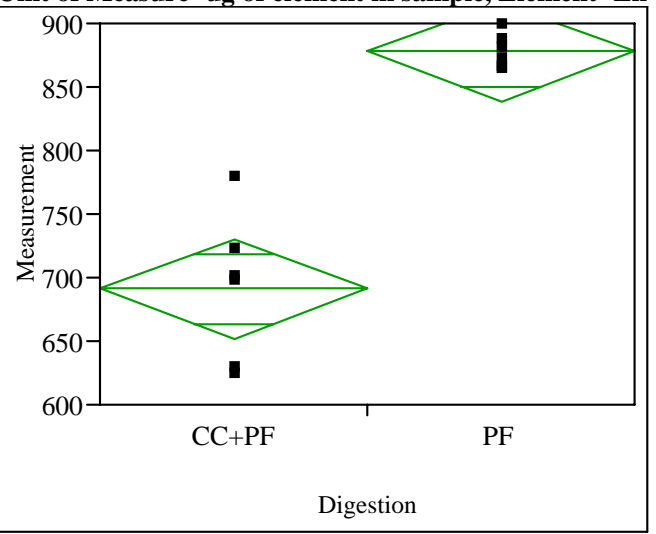

Oneway Anova

Summary of Fit

$\begin{array}{lr}\text { Rsquare } & 0.851777 \\ \text { Adj Rsquare } & 0.836954 \\ \text { Root Mean Square Error } & 42.67093 \\ \text { Mean of Response } & 784.3883 \\ \text { Observations (or Sum Wgts) } & 12\end{array}$

t Test

PF-CC+PF

Assuming equal variances

Difference $\quad 186.757$ t Ratio $\quad 7.580619$

Std Err Dif $\quad 24.636$ DF 10

Upper CL Dif 241.649 Prob $>|t| \quad<.0001$

Lower CL Dif 131.864 Prob $>\mathrm{t} \quad<.0001$

Confidence $\quad 0.95 \mathrm{Prob}<\mathrm{t} \quad 1.0000$

Analysis of Variance

Source DF Sum of Squares Mean Square F Ratio Prob $>$ F

Digestion $11 \quad 104634.16 \quad 10463457.4658<.0001$

$\begin{array}{llll}\text { Error } & 10 & 18208.08 & 1821\end{array}$

C. Total $11 \quad 122842.24$

Means for Oneway Anova

Level Number Mean Std Error Lower 95\% Upper 95\%

$\begin{array}{llllll}\mathrm{CC}+\mathrm{PF} & 6 & 691.010 & 17.420 & 652.20 & 729.82\end{array}$

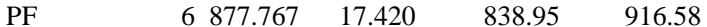

Std Error uses a pooled estimate of error variance

t Test

PF-CC+PF

Assuming unequal variances

Difference $\quad 186.757$ t Ratio $\quad 7.580619$

Std Err Dif 24.636 DF 5.518763

Upper CL Dif 248.336 Prob $>|t| \quad 0.0004$

Lower CL Dif 125.177 Prob $>t \quad 0.0002$

$\begin{array}{lll}\text { Confidence } & 0.95 \text { Prob }<\mathrm{t} \quad 0.9998\end{array}$ 
WSRC-STI-2007-00515

Revision 0

This page intentionally left blank 
WSRC-STI-2007-00515

Revision 0

\section{APPENDIX D}

JMP One-Way Analysis Plots of ARG digested with Boehmite spiked SB4 simulant by DWPF $\mathrm{CC}+\mathrm{PF}$ and $\mathrm{PF}$ 
WSRC-STI-2007-00515

Revision 0

Matched Pairs Element $=\mathbf{A l}$

Difference: Reference Value-CC+PF

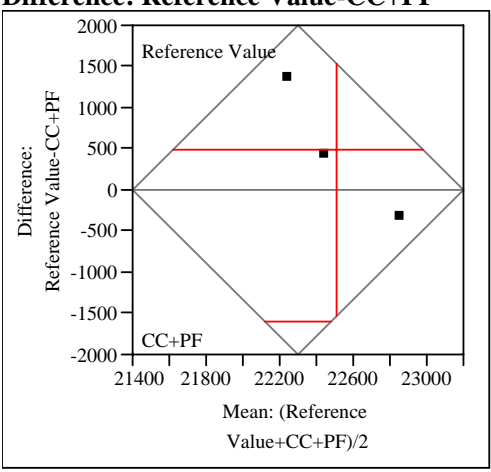

$\begin{array}{lrlr}\text { Reference Value } & 22755 & \text { t-Ratio } & 1.005361 \\ \text { CC+PF } & 22268.3 & \text { DF } & 2 \\ \text { Mean Difference } & 486.707 & \text { Prob }>|t| & 0.4206 \\ \text { Std Error } & 484.111 & \text { Prob }>\text { t } & 0.2103 \\ \text { Upper95\% } & 2569.67 & \text { Prob }<\text { t } & 0.7897 \\ \text { Lower95\% } & -1596.3 & & \\ \text { N } & 3 & & \\ \text { Correlation } & -0.7783 & & \end{array}$

Matched Pairs Element=B

Difference: Reference Value-CC+PF

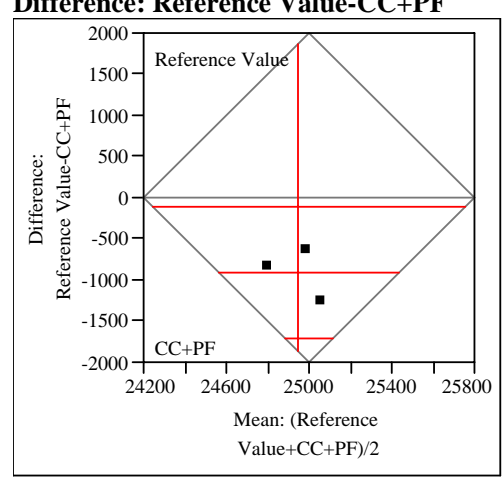

Reference Value 24484.4 t-Ratio $\quad-4.95177$

$\begin{array}{llll}\mathrm{CC}+\mathrm{PF} & 25404.6 & \mathrm{DF} & 2\end{array}$

Mean Difference -920.25 Prob $>|t| \quad 0.0384$

$\begin{array}{llll}\text { Std Error } & 185.843 & \text { Prob }>\mathrm{t} & 0.9808\end{array}$

Upper95\% $\quad-120.63$ Prob $<\mathrm{t} \quad 0.0192$

Lower95\% $\quad-1719.9$

$\mathrm{N}$

3

Correlation $\quad-0.2379$
Matched Pairs Element=Ba

Difference: Reference Value-CC+PF

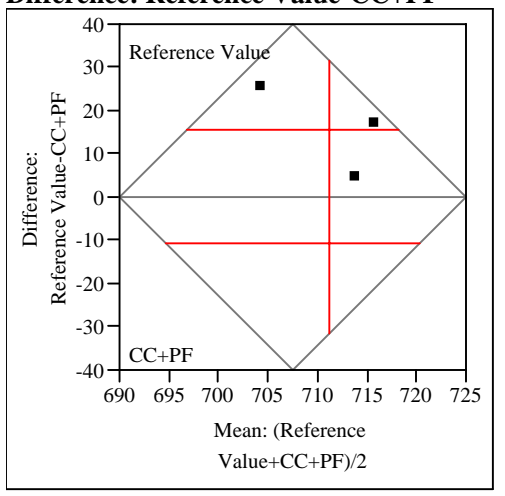

$\begin{array}{lrlr}\text { Reference Value } & 719.058 & \text { t-Ratio } & 2.547199 \\ \text { CC+PF } & 703.467 & \text { DF } & 2 \\ \text { Mean Difference } & 15.5913 & \text { Prob }>|t| & 0.1257 \\ \text { Std Error } & 6.12097 & \text { Prob }>\text { t } & 0.0629 \\ \text { Upper95\% } & 41.9277 & \text { Prob }<\text { t } & 0.9371 \\ \text { Lower95\% } & -10.745 & & \\ \text { N } & 3 & & \\ \text { Correlation } & 0.20519 & & \end{array}$

Matched Pairs Element $=\mathrm{Ca}$ Difference: Reference Value-CC+PF

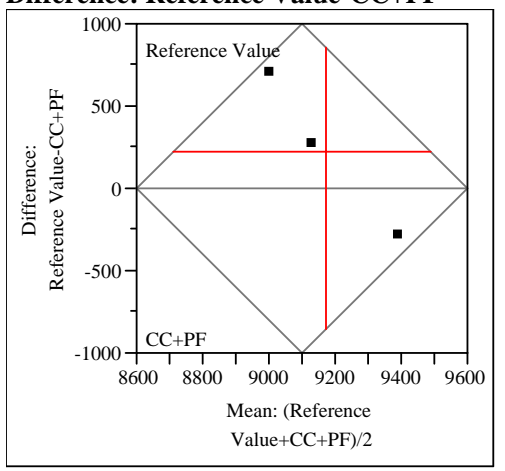

$\begin{array}{lrlr}\text { Reference Value } & 9284.04 & \text { t-Ratio } & 0.785388 \\ \text { CC+PF } & 9058.4 & \text { DF } & 2 \\ \text { Mean Difference } & 225.64 & \text { Prob }>|t| & 0.5145 \\ \text { Std Error } & 287.298 & \text { Prob }>\text { t } & 0.2572 \\ \text { Upper95\% } & 1461.78 & \text { Prob }<\mathrm{t} & 0.7428 \\ \text { Lower95\% } & -1010.5 & & \\ \text { N } & 3 & & \\ \text { Correlation } & -0.8552 & & \end{array}$


WSRC-STI-2007-00515

Revision 0

Matched Pairs Element $=$ Co

Difference: Reference Value-CC+PF

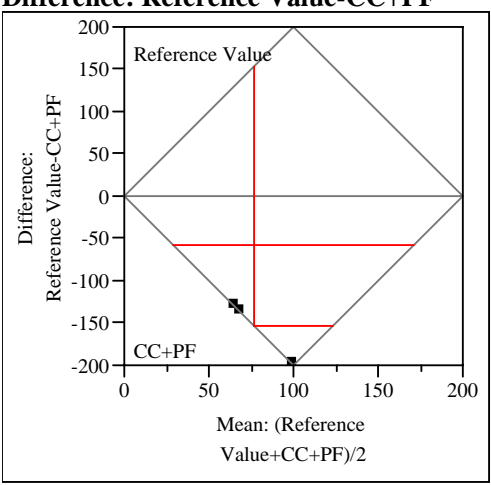

$\begin{array}{lrlr}\text { Reference Value } & 0 & \text { t-Ratio } & -6.95197 \\ \text { CC+PF } & 153.997 & \text { DF } & 2 \\ \text { Mean Difference } & -154 & \text { Prob }>|t| & 0.0201 \\ \text { Std Error } & 22.1515 & \text { Prob }>\text { t } & 0.9900 \\ \text { Upper95\% } & -58.686 & \text { Prob }<\text { t } & 0.0100 \\ \text { Lower95\% } & -249.31 & & \\ \text { N } & 3 & & \\ \text { Correlation } & 0 & & \end{array}$

Matched Pairs Element $=\mathbf{C r}$

Difference: Reference Value-CC+PF

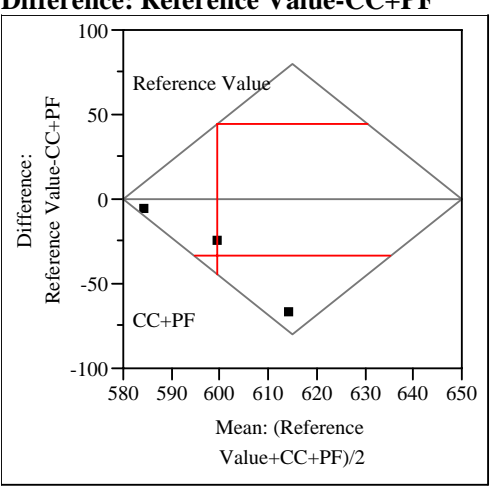

$\begin{array}{lrlr}\text { Reference Value } & 582.528 & \text { t-Ratio } & -1.86183 \\ \text { CC+PF } & 616.21 & \text { DF } & 2 \\ \text { Mean Difference } & -33.682 & \text { Prob }>|t| & 0.2037 \\ \text { Std Error } & 18.0908 & \text { Prob }>\text { t } & 0.8982 \\ \text { Upper95\% } & 44.1566 & \text { Prob }<\mathrm{t} & 0.1018 \\ \text { Lower95\% } & -111.52 & & \\ \text { N } & 3 & & \\ \text { Correlation } & -0.2116 & & \end{array}$

Matched Pairs Element=Fe

Difference: Reference Value-CC+PF

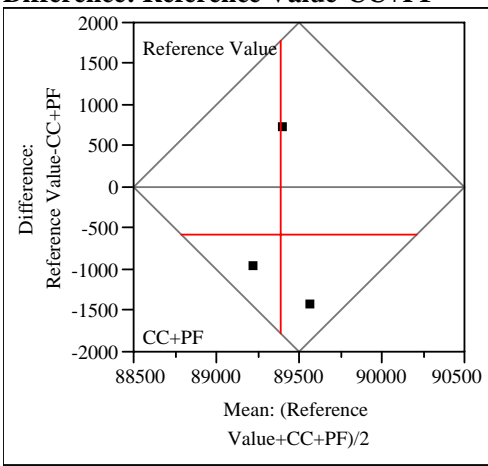

$\begin{array}{lrlr}\text { Reference Value } & 89108.6 & \text { t-Ratio } & -0.86912 \\ \text { CC+PF } & 89679.5 & \text { DF } & 2 \\ \text { Mean Difference } & -570.94 & \text { Prob }>|t| & 0.4764 \\ \text { Std Error } & 656.917 & \text { Prob }>\text { t } & 0.7618 \\ \text { Upper95\% } & 2255.55 & \text { Prob }<\text { t } & 0.2382 \\ \text { Lower95\% } & -3397.4 & & \\ \text { N } & 3 & & \\ \text { Correlation } & -0.8307 & & \end{array}$

Matched Pairs Element $=K$ Difference: Reference Value-CC+PF

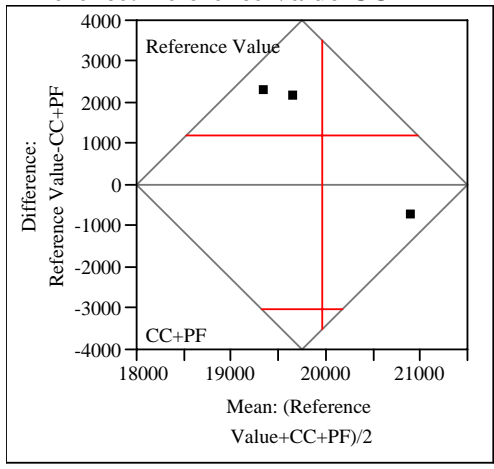

Reference Value 20570.5 t-Ratio 1.230693 CC+PF 19351.3 DF 2

Mean Difference 1219.21 Prob $>|t| \quad 0.3435$

$\begin{array}{llll}\text { Std Error } & 990.67 & \text { Prob }>t & 0.1718\end{array}$

Upper95\% 5481.72 Prob $<\mathrm{t} \quad 0.8282$

Lower95\% - -3043.3

$\mathrm{N} \quad 3$

Correlation $\quad-0.2973$ 
WSRC-STI-2007-00515

Revision 0

Matched Pairs Element=Li

Difference: Reference Value-CC+PF

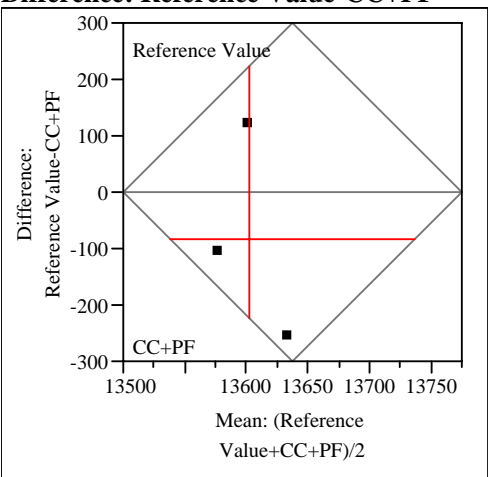

$\begin{array}{lrlr}\text { Reference Value } & 13562 & \text { t-Ratio } & -0.74989 \\ \text { CC+PF } & 13643.9 & \text { DF } & 2 \\ \text { Mean Difference } & -81.96 & \text { Prob }>|t| & 0.5315 \\ \text { Std Error } & 109.297 & \text { Prob }>\text { t } & 0.7342 \\ \text { Upper95\% } & 388.305 & \text { Prob }<\text { t } & 0.2658 \\ \text { Lower95\% } & -552.23 & & \\ \text { N } & 3 & & \\ \text { Correlation } & -0.8618 & & \end{array}$

Matched Pairs Element=Mg

Difference: Reference Value-CC+PF

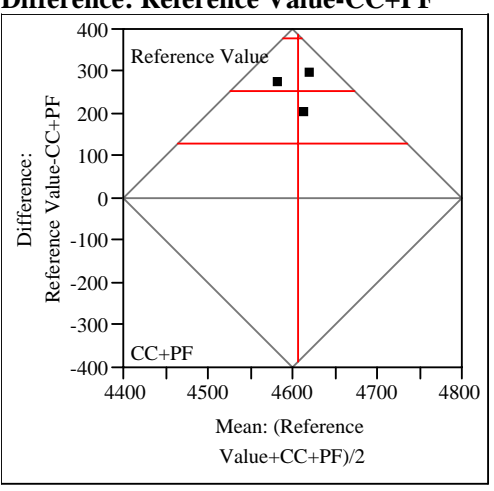

$\begin{array}{lrlr}\text { Reference Value } & 4733.04 & \text { t-Ratio } & 8.756483 \\ \text { CC+PF } & 4478.39 & \text { DF } & 2 \\ \text { Mean Difference } & 254.653 & \text { Prob }>|t| & 0.0128 \\ \text { Std Error } & 29.0817 & \text { Prob }>\text { t } & 0.0064 \\ \text { Upper95\% } & 379.782 & \text { Prob }<\text { t } & 0.9936 \\ \text { Lower95\% } & 129.525 & & \\ \text { N } & 3 & & \\ \text { Correlation } & -0.2202 & & \end{array}$

Matched Pairs Element=Mn

Difference: Reference Value-CC+PF

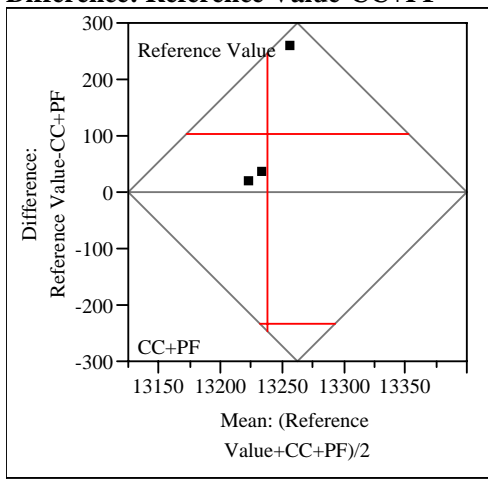

$\begin{array}{lrlr}\text { Reference Value } & 13288.9 & \text { t-Ratio } & 1.312592 \\ \text { CC+PF } & 13187.1 & \text { DF } & 2 \\ \text { Mean Difference } & 101.837 & \text { Prob }>|t| & 0.3197 \\ \text { Std Error } & 77.5844 & \text { Prob }>\text { t } & 0.1599 \\ \text { Upper95\% } & 435.655 & \text { Prob }<\text { t } & 0.8401 \\ \text { Lower95\% } & -231.98 & & \\ \text { N } & 3 & & \\ \text { Correlation } & -0.9914 & & \end{array}$

Matched Pairs Element $=\mathrm{Na}$

Difference: Reference Value-CC+PF

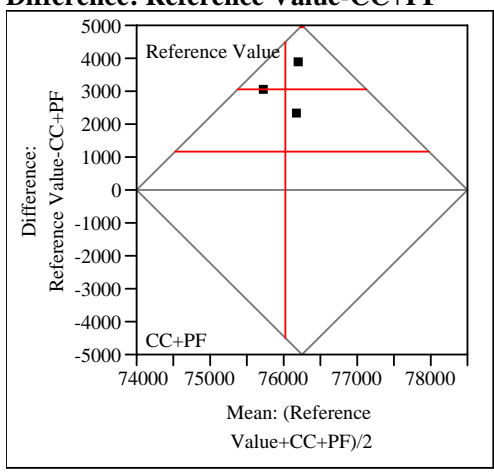

$\begin{array}{lrlr}\text { Reference Value } & 77549 & \text { t-Ratio } & 6.899629 \\ \text { CC+PF } & 74520 & \text { DF } & 2 \\ \text { Mean Difference } & 3029.08 & \text { Prob }>|t| & 0.0204 \\ \text { Std Error } & 439.021 & \text { Prob }>\text { t } & 0.0102 \\ \text { Upper95\% } & 4918.03 & \text { Prob }<\text { t } & 0.9898 \\ \text { Lower95\% } & 1140.13 & & \\ \text { N } & 3 & & \\ \text { Correlation } & -0.3324 & & \end{array}$


WSRC-STI-2007-00515

Revision 0

Matched Pairs Element=Ni

Difference: Reference Value-CC+PF

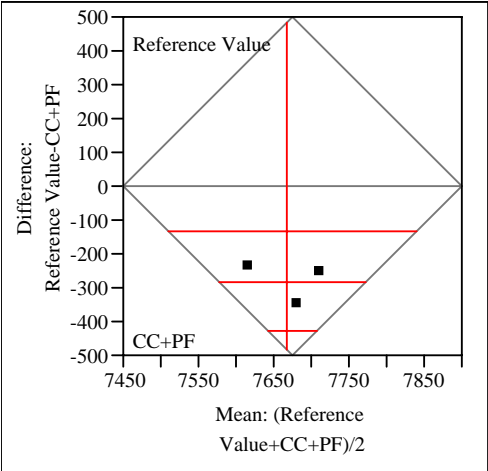

$\begin{array}{lrlr}\text { Reference Value } & 7527.35 & \text { t-Ratio } & -8.24734 \\ \text { CC+PF } & 7808.08 & \text { DF } & 2 \\ \text { Mean Difference } & -280.73 & \text { Prob }>|t| & 0.0144 \\ \text { Std Error } & 34.0388 & \text { Prob }>\mathrm{t} & 0.9928 \\ \text { Upper95\% } & -134.27 & \text { Prob }<\mathrm{t} & 0.0072 \\ \text { Lower95\% } & -427.19 & & \\ \text { N } & 3 & & \\ \text { Correlation } & 0.49671 & & \end{array}$

Matched Pairs Element=Si

Difference: Reference Value-CC+PF

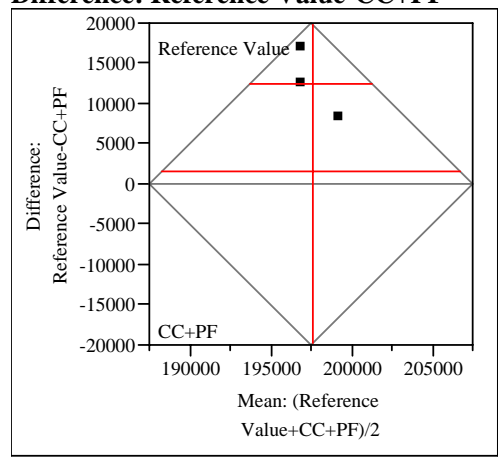

$\begin{array}{lrlr}\text { Reference Value } & 203885 & \text { t-Ratio } & 4.930434 \\ \text { CC+PF } & 191372 & \text { DF } & 2 \\ \text { Mean Difference } & 12513.1 & \text { Prob }>|t| & 0.0388 \\ \text { Std Error } & 2537.92 & \text { Prob }>\text { t } & 0.0194 \\ \text { Upper95\% } & 23432.9 & \text { Prob }<\mathrm{t} & 0.9806 \\ \text { Lower95\% } & 1593.26 & & \\ \text { N } & 3 & & \\ \text { Correlation } & -0.6918 & & \end{array}$

Matched Pairs Element=Sn Difference: Reference Value-CC+PF

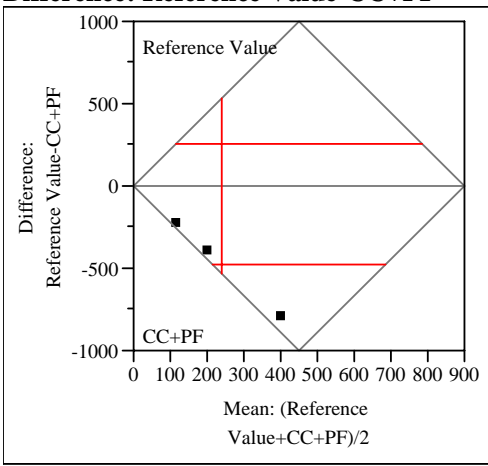

$$
\begin{array}{lrlr}
\text { Reference Value } & 0 & \text { t-Ratio } & -2.81037 \\
\text { CC+PF } & 477.563 & \text { DF } & 2 \\
\text { Mean Difference } & -477.56 & \text { Prob }>|t| & 0.1067 \\
\text { Std Error } & 169.929 & \text { Prob }>\text { t } & 0.9466 \\
\text { Upper95\% } & 253.581 & \text { Prob }<\mathrm{t} & 0.0534 \\
\text { Lower95\% } & -1208.7 & & \\
\text { N } & 3 & & \\
\text { Correlation } & 0 & &
\end{array}
$$

Matched Pairs Element=Ti Difference: Reference Value-CC+PF

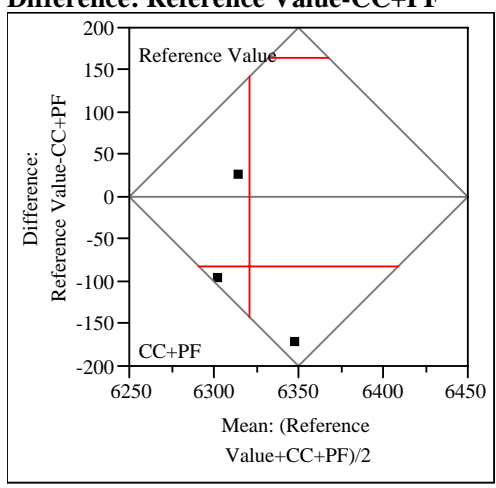

$\begin{array}{lrlr}\text { Reference Value } & 6280.38 & \text { t-Ratio } & -1.43705 \\ \text { CC+PF } & 6362.55 & \text { DF } & 2 \\ \text { Mean Difference } & -82.173 & \text { Prob }>|t| & 0.2873 \\ \text { Std Error } & 57.1819 & \text { Prob }>\text { t } & 0.8564 \\ \text { Upper95\% } & 163.861 & \text { Prob }<\mathrm{t} & 0.1436 \\ \text { Lower95\% } & -328.21 & & \\ \text { N } & 3 & & \\ \text { Correlation } & -0.712 & & \end{array}$


WSRC-STI-2007-00515

Revision 0

Matched Pairs Element $=V$

Difference: Reference Value-CC+PF

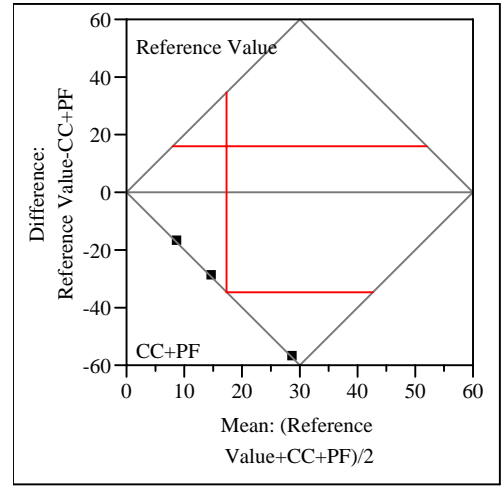

$\begin{array}{lrlr}\text { Reference Value } & 0 & \mathrm{t}-\text { Ratio } & -2.95848 \\ \text { CC+PF } & 34.7433 & \text { DF } & 2 \\ \text { Mean Difference } & -34.743 & \text { Prob }>|t| & 0.0978 \\ \text { Std Error } & 11.7436 & \text { Prob }>\mathrm{t} & 0.9511 \\ \text { Upper95\% } & 15.7855 & \text { Prob }<\mathrm{t} & 0.0489 \\ \text { Lower95\% } & -85.272 & & \\ \text { N } & 3 & & \\ \text { Correlation } & 0 & & \end{array}$

Matched Pairs Element $=\mathrm{Zr}$

Difference: Reference Value-CC+PF

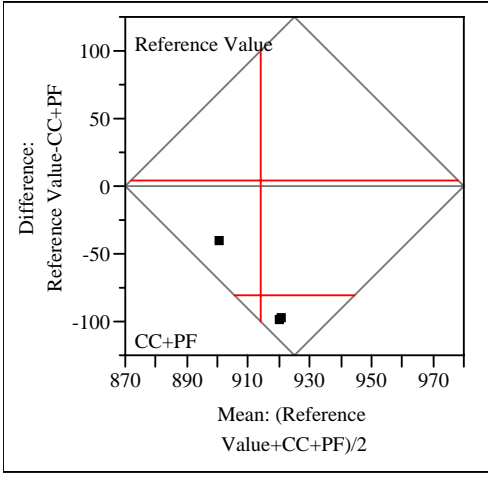

Reference Value 873.792 t-Ratio $\quad-4.11975$

$\mathrm{CC}+\mathrm{PF}$

953.883

Mean Difference -80.091 Prob $>|\mathrm{t}| \quad 0.0542$

$\begin{array}{llll}\text { Std Error } & 19.4408 & \text { Prob }>t & 0.9729\end{array}$

Upper95\% $\quad 3.55588$ Prob $<\mathrm{t} \quad 0.0271$

Lower95\% $\quad-163.74$

Correlation $\quad-0.9937$ 